\title{
Solar Energy Legal Bibliography Final Report
}

\author{
Dwight Seeley \\ Barbara Euser \\ Craig Joyce \\ George H. Morgan \\ Jan G. Laitos \\ Addison Adams
}
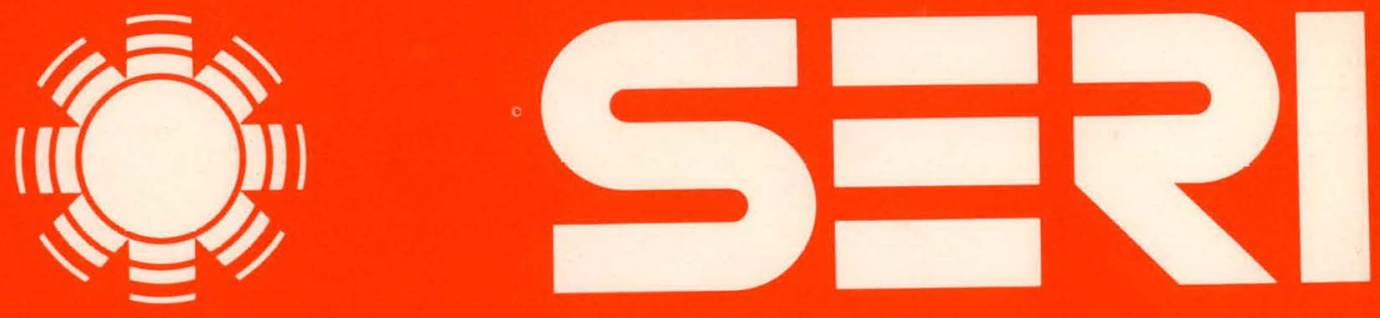

Solar Energy Research Institute

A Division of Midwest Research Institute

1536 Cole Boulevard

Golden, Colorado 80401

Operated for the

U.S. Department of Energy under Contract No. EG-77-C-01-4042

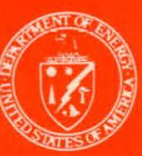




\section{DISCLAIMER}

This report was prepared as an account of work sponsored by an agency of the United States Government. Neither the United States Government nor any agency Thereof, nor any of their employees, makes any warranty, express or implied, or assumes any legal liability or responsibility for the accuracy, completeness, or usefulness of any information, apparatus, product, or process disclosed, or represents that its use would not infringe privately owned rights. Reference herein to any specific commercial product, process, or service by trade name, trademark, manufacturer, or otherwise does not necessarily constitute or imply its endorsement, recommendation, or favoring by the United States Government or any agency thereof. The views and opinions of authors expressed herein do not necessarily state or reflect those of the United States Government or any agency thereof. 


\section{DISCLAIMER}

Portions of this document may be illegible in electronic image products. Images are produced from the best available original document. 


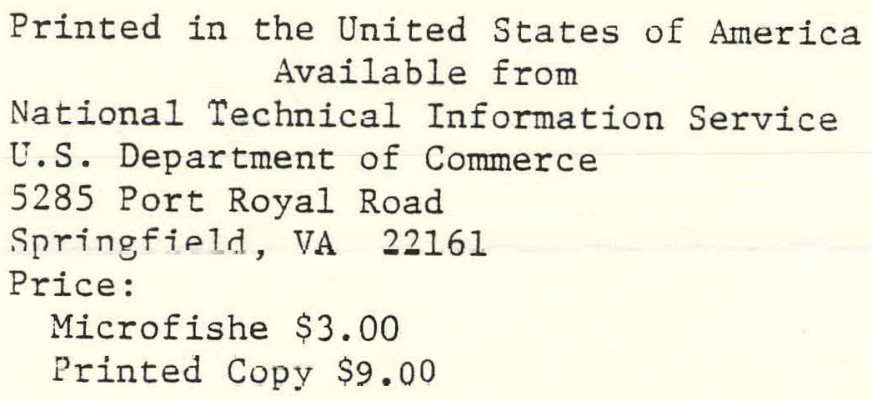

NOTICE

This report was prepared as an account of work sponsored by the United States Government. Neither the United States nor the United States Department of Energy, nor any of their employees, nor any of their contractors, subcontractors, or their employees, makes any warranty, express or implied, or assumes any legal liability or responsibility for the accuracy, completeness or usefulness of any information, apparatus, product or process disclosed, or represents that its use would not infringe privately owned rights. 
SER I /TR-62-069

UC CATEGORY: UC-59,60,61,62,

63,64

SOLAR ENERGY LEGAL BIBLIOGRAPHY

F INAL REPORT

DWIGHT SEELEY

BARBARA EUSER

CRATG JOYCE

GEORGE H. MORGAN

JAN G. LAITOS

ADDISON ADAMS

MARCH 1979

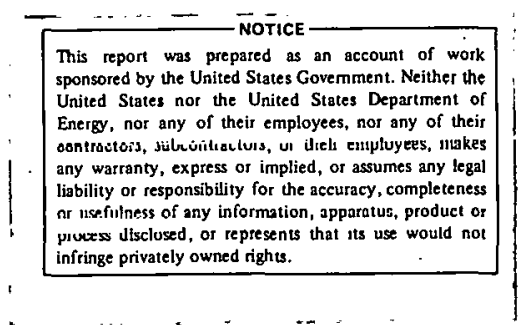

Solar Energy Research Institute 9586687

1536 Cole Boulevard

Golden, Colorado 80401

A Division of Midwest Research Institute

Prepared for the

U.S. Department of Energy

Contract No. EG.77.C.01.4042 
FOREWORD

This bibliography was prepared by the Solar Energy Research Institute to fulfill, in part, SERI's solar information dissemination function. The bibliography is part of the Market Development Branch Law Program as a part of the overall program of the Technology Commercialization Division. The bibliography is intended to make a comprehensive, abstracted complifiation of publications pertaining to law and solar energy readily available to interested persons. The bibliography will be updated at periodic intervals, and such updates will be published in the Solar Law Reporter, another SERI publication.

The concept of a Solar Energy Legal Bibliography began with George Morgan, Senior Legal Analyst with SERI. The bulk of the organization and abstracting for the bibliography was performed by Barbara Euser and Craig Joyce, law students at the University of Denver College of Law. They were assisted by Addison Adams and Dwight Seeley, who are also Denver Law School students. Dwight Seeley was responsible for final editing and revision. The initial 1iterature searches, both computer and manual, were done by Joan McConkey, librarian at the University of Colorado Law School. SERI staff members contributing to the bibliography were Saundra Smith, Annette Berger, Eileen McIlvain, Art Adams, Nancy Greer, and Larry Preston, data acquisition; and Ken Rourke and Joyce M. Wilson, design and format. Professor Jan Laitos, SERI Visiting Law Professor, provided significant input and advice. George Morgan was project leader.

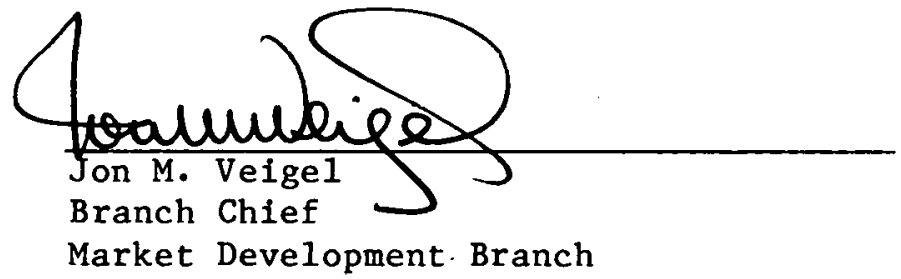

Approved for:

SOLAR ENERGY RESEARCH INSTITUTE

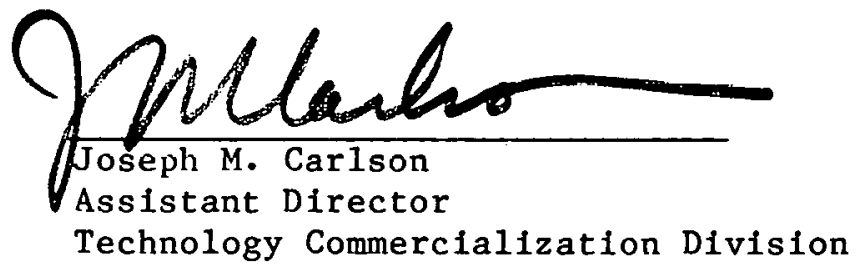


Introduction. . . . . . . . . . . . . . . . . . . iv

Table of Cases . . . . . . . . . . . . . . . . . . . . viii Abstract ........................... . ix

1.0 Antitrust. . . . . . . . . ............ 1

2.0 Biomass. . . . . . . . . . . . . . . . . . 5

3.0 Building Codes . . . . . . . . . . . . . . . . . . 7

4.0 Consumer Protection . . . . . . . . . . . . . . . 13

5.0 Environmental Aspects. . . . . . . . . . ..... 15

6.0 Federal Legislation and Programs . . . . . . . . . . . . 19

7.0 Financing/Insurance. . . . . . . . . . . . . . . . 31

8.0 International Law. . . . . . . . . . . . . . . . 43

9.0 Labor ............................. 51

10.0 Land Use: Covenants, Easements, Nuisance, Zoning . . . . . 52

11.0 Local Legislation and Programs . . . . . . . . . . . 67

12.0 Ocean Energy ........................ 71

13.0 Patents and Licenses . . . . . . . . . . . . 79

14.0 Photovoltaics. . . . . . . . ....... 81

15.0 Solar Access Rights. . . . . . . . . . . . . . . 83

16.0 Solar Heating and Cooling. . . . . . . . . . 93

17.0 Solar Thermal Power Systems. . . . . . . . . . . 101

18.0 Standards. . . . . . . . . . . . . . . . 103

19.0 State Legislation and Programs . . . . . . . . . . . 107

20.0 Tax Law. . . . . . . . . . . . . . . . . . 117

21.0 Tort Liability . . . . . . . . . . . . . . . . . 121

22.0 Utilities. . . . . . . . . . . . . . . . . . . 123

23.0 Warranties . . . . . . . . . . . . . . . . . 131

24.0 Wind Resources . . . . . . . . . . . . . . . . . 133

25.0 General Solar Law. . . . . . . . . . . . . . . . 137

Author/Title Index . . . . . . . . . . . . . . . . 149 


\section{INTRODUCTION}

This bibliography contains abstracts of 160 publications dealing with solar energy development and the law. Because the abstracts focus only on the legal issues presented in the publications, they may not entirely reflect the complete contents of the documents abstracted.

Potentially relevant materials were culled from citations in standard subject indexes and computer-assisted data base searches. The search for documents was not limited to legal literature. Publications from all potentially relevant fields of inquiry were sought, reviewed, and abstracted where appropriate. The cut-off deadline for articles appearing in the bibliography was October 1, 1978.

The search for publications containing solar law issues produced citations to approximately 400 potentially relevant documents. of these, approximately 300 documents were located and evaluated, and of these 300,160 were deemed within the scope of this bibliography. The topic headings and a brief description of the scope of each are listed at the end of the Introduction.

At the time of publication, copies of approximately one-fourth of the total number of potentially relevant citations had not been received. Therefore, some relevant materials may have been omitted simply because they were not received in time to prepare an abstract for this publication.

Planned future updates, which will be published periodically in the Solar Law Reporter, will include new abstracts of relevant publications located subsequent to publication of this bibliography. Users of this bibliography are encouraged to bring relevant materials to the attention of SERI so that such materials may be included in future updates. SERI also solicits reader comments on errors and omissions. Comments should be addressed to: Ceorge Morgan, Senior Legal Analyst, Technology Commercialization Division, Market Development Branch, Solar Energy Research Institute, 1536 Cole Boulevard, Golden, Co 80401 .

In order to aid in the acquisition of these documents, sources of availability follow each citation. In most cases, the documents may be located at your local public, academic, or organization libraries. If such a library does not have the document, it may borrow it from another library.

Purchase information is also provided. The two major sources are the Government Printing office (GPO) and the National Technical Information Service (NTIS). Their addresses are:

Superintendent of Documents

Government Printing office

Washington, DC 20402

Stock No. 061-000-00302-9 
National Technical Information Service

U.S. Department of Commerce

5285 Port Royal Road

Springfield, VA 22161

Prices are provided for both printed copy (PC) and Microfiche (MF).

If a local library is unable to obtain the documents through its regular interlibrary loan channels, the library may submit the interlibrary loan request to:

Solar Energy Information Center

Solar Energy Research Tnstitute

1536 Cole Boulevard

Golden, CO 80401

Each abstract is listed under the topic of primary concentration addressed by the article. It should be noted, however, that many of the articles abstracted touch upon a number of topics within the solar energy legal area. Additionally, there are fine distinctions between some topics, and the result is that many sources straddle subject areas. For example, most sources discussing ANTITRUST concentrate that discussion in the UTILITIES area; similarly, most articles dealing with SOLAR ACCESS RIGHTS also discuss LAND USE issues. Users of the bibliography should recognize the limitations inherent in classifying sources as broad in scope as many in the solar energy field. For these reasons, all abstracts are cross-referenced to other topic areas that are discussed in the article. To further aid the researcher, an author/titlo index is inrluded.

1.0 ANTITRUST: An emerging solar industry will require legal scrutiny, especially where large utilities are concerned. Abstracted materials discuss legal problems and incentives in utility involvement, backup systems, peak-power pricing and regulations. See UTILITIES.

2.0 BIOMASS: Legal problems and incentives in obtaining energy from waste and biomass (material derived from growing organisms).

3.0 BUILDING CODES: Existing codes and model codes. Impediments to solar development because of a lack of or conflicting codes. 
4.0 CONSUMER PROTECTION: Includes government efforts to protect solar product buyers through testing facilities, codes and standards, and promoting of an industry-wide code of ethics.

5.0 ENVIRONMENTAL ASPECTS: The solar energy impact on air quality, water quality, and land use.

6.0 FEDERAL LEGISLATION AND PROGRAMS: Federal legislation and policy concerning incentives to solar growth: creation of federal solar agencies (for regulation and promotion of solar energy), grants and subsidies, income tax deductions, low-interest and guaranteed loans, government insurance, demonstration programs, and deregulation of oil and gas. Included are reviews of solar legislation from the 93rd, $94 \mathrm{th}$, and $95 \mathrm{th}$ Congressional sessions and reports from Congressional committees.

7.0 FINANCING/INSURANCE: Discussion of financial barriers and incentives to solar installation, including government subsidies, loans, mortgages, life-cycle cost estimates, and interest rates.

8.0 INTERNATIONAL LAW: Descriptions of solar energy law and development programs outside of the United States. Includes some case law and descriptions of existing international solar energy agreements.

9.0 LABOR: Present impediments to solar development in the construction industry.

10.0 LAND USE: Cases and articles on the legality and feasibility of solar development through existing and proposed covenants and easements. Land use planning regulations and zoning. Nuisance law. See SOLAR ACCESS.

11.0 LOCAL LEGISLATION AND PROGRAMS: Existing and proposed local and municipal programs to accelerate and regulate solar energy installation.

12.0 OCEAN ENERGY: Legal, regulatory, financing and political ramifications of energy production from OTEC and wind energy devices.

13.0 PATENTS AND LICENSES: Potential patent and licensing problems in development and manufacture of solar devices and systems.

14.0 PHOTOVOLTAICS: Commercialization problems and the relationship of photovoltaic systems to the electric utility industry.

15.0 SOLAR ACCESS RIGHTS: Case law dealing with legal issues involved in securing direct sunlight for solar collectors. Included are such issues as the doctrine of ancient lights, taxation of airspace, constitutional questions in federal legislation, the prior appropriation doctrine, and related issues. See LAND USE. 
16.0 SOLAR HEATING AND COOLING: Standards, technology commercialization programs, the impact of solar heating and cooling systems on the electric utilities, and legal issues in this area of solar technology.

17.0 SOLAR THERMAL POWER SYSTEMS: Legal impediments and 1ncentives in this area of solar technology.

18.0 STANDARDS: Existing standards are examined and standard development programs are charted in the areas of health and safety, testing, and minimum levels of technical performance.

19.0 STATE LEGISLATION AND PROGRAMS: State legislative programs include the establishment of solar energy offices, state regulation of solar growth, tax incentives, retrofitting and building codes, and research and demonstration programs.

20.0 TAX LAW: Federal and state programs to provide incentives to installation of solar units.

21.0 TORT LIABILITY: Liability and fault for defective or nonperforming solar devices or solar systems.

22.0 UTILITIES: Lega1, regulatory, antitrust ratemaking, and backup power issues needing resolution because of the close association of the utilities and the solar power industry.

23.0 WIND RESOURCES: Legal issues regarding the utilization of wind generated electric power, including zoning, building codes, aesthetics, and regulation of both land-based and offshore wind energy conversion systems (WECS).

24.0 WARRANTIES: Legal problems in protecting consumers of solar energy devices. See CONSUMER PROTECTION.

25.0 GENERAL SOLAR LAW: Abstracts of articles surveying solar energy development. Articles discuss legal issues in many of the previously listed subject areas. 


\section{TABLE OF CASES}

Page

Bury v. Pope, 1 Cros. Eliz. 118, 78 Eng. Rep. 375 (Exc. 1586). • • 43

Charles Semon and Co. Ltd. v. Bradford Corp., 2 Ch. 737 (1922). • • 43

Cohen v. Perrino, $355 \mathrm{~Pa}$. 455, 50 A 2d 348 (1947) . . . . . . . . 84

Colls v. Home and Colonial Stores Ltd., H.L. (E.) \#179 (1904). . • • . 44

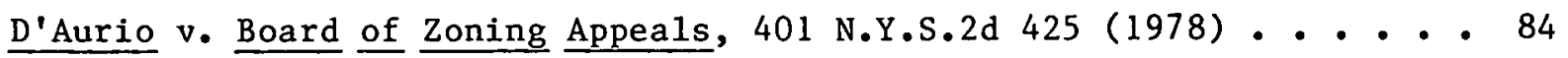

Fontainbleau Hotel Corp. v. Forty-five Twenty-five, Inc.,

114 So. $2 \mathrm{~d} 357(\mathrm{Fla}$. 1959). . . . . . 85

Maiorello v. Arlotta, $364 \mathrm{~Pa} 557,73$ A.2d 374 (1950). . . . . . 87

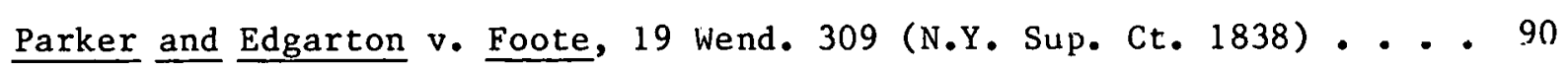

United States v. Causby, 328 U.S. 256 (1946). . . . . . . . . . 63 


\begin{abstract}
The Solar Energy Legal Bibliography is a compilation of approximately 160 solar publications abstracted for their legal and policy content (through October 1978). Emphasis is on legal barriers and incentives to solar energy development. Abstracts are arranged under the following categories: Antitrust, Biomass, Building Codes, Consumer Protection, Environmental Aspects, Federal Legislation and Programs, Financing/ Insurance, International Law, Labor, Land Use (Covenants, Easements, Nuisance, Zoning), Local Legislation and Programs, Ocean Energy, Patents and Licenses, Photovoltaics, Solar Access Rights, Solar Heating and Cooling, Solar Thermal Power Systems, Standards, State Legislation and Programs, Tax Law, Tort Liability, Utilities, Warranties, Wind Resources, and General Solar Law.
\end{abstract}


Section 1.0

ANTITRUST

Barnes, Peter. "Who'11 Control Sun Power? The Solar Derby." The New Republic, pp. 17-19; February 1, 1975.

See GENERAL

Bezdek, Roger. "Legal and Regulatory Issues." Chapter IV in Analysis of Policy Options for Accelerating Commercialization of Solar Heating and Cooling Systems. Washington, DC: The Ceorge Washington University, $19 \overline{77}$. 467 p.

See LAND USE

Bossong, Ken. "The Case Against Private Utility Involvement in Solar/ Insulation Programs." Washington, DC: Center for Science in the Public Interest, 1977.

Available from: Citizen's Energy Project, $1413 \mathrm{~K}$ Street, NW, 8th Floor, Washington, DC 20005, \$.50.

Arguments against the involvement of investor-owned utilities in the development of solar energy need further discussion. Potential problems arising from such private utility involvement include: (1) excessive profit taking might reduce or eliminate the competitiveness of solar energy with nuclear and fossil fuels; (2) private utility monopolization of the solar field would discourage smaller industries, leading to uncompetitive pricing, and, in the home insulation market, eliminate independent contractors by unfairly exploiting the utility's prior access to the customer; and (3) customers may be forced to accept rate structures that subsidize the utilities' installation and research and development costs, while paying higher rates on their declining energy usage. 


\section{ANTTTRUST (Continued)}

Private utilities are also criticized for poor energy planning and for demonstrating a lack of commitment to the development of solar energy. Alternatives to involving private utilities in solar energy development should be fully aired and debated through public hearings prior to action by state legislatures and the Congress.

Dean, Norman L.; Miller, Alan S. "Plugging Snlar Fnergy into the Utility Crid." Environmental Law Reporter. Vol. 7 pp. 50069-50082; 1977.

Available from: Local library.

Integration of solar technology with the utilities services may result in rate and service discrimination as found in variable demand pricing, regulatory burdens on multi-user solar systems, and the possible direct involvement of utilities in the solar energy market.

State statutes prohibit the state public utilities commissions (PUC) from discrimination against power users hut allnw for proferential treatmont of cerca1n types of users. Hederal antitrust laws might provide a remedy for solar users against utility discrimination. Service discrimination would violate the utilities' common law and statutory duty to provide utility service. Judicial review of state PUC decisions is also available, but only after all administrative remedies are exhausted.

Miller, Alan S. "Solar Energy and Land Use in Colorado." Environmental Law Reporter. Vul. 6 pp. 50039-50046; July, 1976.

See LAND USE 


\section{ANTITRUST (Continued)}

U.S. Congress. House. Committee on Science and Technology. Solar Energy Legislation Through the 94 th Congress. U.S. Library of Congress, Congressional Research Service, Science Policy Research Division, Washington, DC: Government Printing Office; 1976.

See FEDERAL LEGISLATION AND PROGRAMS

U.S. Federal Trade Commission. Bureau of Competition. The Solar Market: Proceedings of the Symposium on Competition in the Solar Energy Industry. Washington, DC: Government Printing Office; June, 1978 .

See STANDARDS 
THIS PAGE INTENTIONALLY LEFT BLANK 
Section 2.0

BIOMASS

Burke, Kenneth J. "Alternative Forms of Energy." Lecture, Environmental Law for the Colorado Practitioner. Reprinted by Continuing Legal Education in Colorado, Inc., Denver, $1975^{\circ}$

See GENERAL

U.S. Energy Research and Development Administration. A National P1an for Energy Research, Development, and Demonstration: Creating Energy Choices for the Future. June, 1977 .

Available from: Local library; NTIS, Report No. ERDA 76-1.

To help solve the Nation's energy problems, new technology must be developed to (1) increase the efficiency of energy use, (2) expand the use of existing fuels, and (3) make the transition to new fuels. This report presents the Energy Research and Development Administration's effort in these three areas.

Brief summaries are given of efforts underway in solar heating and cooling, energy from waste and biomass, and solar electric systems, including photovoltaic, thermal electric, wind energy, and ocean thermal systems.

U.S. Federal Energy Administration. Project Independence Blueprint: Final Task Force Report, Solar Energy. Washington, DC: Government Printing Office; 1974 .

See GENERAL 
THIS PAGE INTENTIONALLY LEFT BLANK 
Section 3.0

BUILDING CODES

AIA Research Corporation. Early Use of Solar Energy in Buildings: A Study of Barriers and Incentives to the Widespread Use of Solar Heating and Cooling Systems. Washington, $\overline{D C}$ : August, 1976.

Available from: Local library; NTIS, Report No. PB 267832 , PC \$9.00, MF $\$ 3.00$.

This report analyzes solar energy with respect to: (1) regulation of buildings for health and safety, land use, and public utilities; and (2) consumer rights and powers.

The right to receive sunlight is not protected in American law, except by express agreement. Zoning could be used to insure solar access, as could the adoption of a wholly public concept of ownership of solar energy.

At present there is no substantiation of the belief that building codes impede solar progress. Likewise, the present lack of warranty protection is not a barrier per se but a characteristic of an undeveloped market. The need for mass solar installation can best be met with legislative solutions. Antitrust law will assure close scrutiny of local utility involvement in solar energy.

The report concludes with a review of proposed federal legislation to provide incentives for the development of solar heating and cooling.

Anderson, Bruce. "The Sun in a Drawer." Environment Vol. 17 (No. 7) pp. 36-41; October, 1975.

Available from: Local Library.

Intensive promotion of solar energy use requires extensive integration of colar energy systoms into a complex structure of existing housing regula- 


\section{BUILDING CODES (Continued)}

tions, tax laws, mortgage constraints, building codes, construction standards, manufacturing restraints, and labor requirements.

Potential solar users may be deterred by the facts that solar energy is presently practical for only $50 \%$ to $75 \%$ of heating needs, and the initial costs are high. The government may reduce the initial costs with incentives, loans, and subsidies.

Building codes, fire codes, health codes, and zoning restrictions must be tallored to eliminate potential negative impacts on solar energy systems. Legislation creating rights to protect solar energy users nay be needed.

Binns, W. Patrick. "State Legislative Initiatives for Solar Energy Implementation." Industrialization Forum. Vol. 7 (No. 2-3): pp. 3-9; 1976.

See STATE LEGISLATION AND PROGRAMS

Bezdek, Roger, "Building Codes, Standards, and Warranties." Chapter $V I$ in Analysis of Policy Options for Acceleraling Commerclallzation of Solar Heating and Cooling Systems. Washington, DC: The George Washington University; $1977.467 \mathrm{p}$.

Available from: Local library: NTIS, Report No. TID-27597, PC \$14.50, MF $\$ 3.00$.

Neither the three model building codes prevalent in the United States nor their companion mechanical and plumbing codes specifically mention or provide for solar Héating and looling ('illac') systems. Cunsequently, Lhese model codes and the many local codes based on them may present serious obstacles to the widespread use of SHAC systems. Building officials might use their discretionary power to require applicants to prove that their solar systems comply satisfactorily with code requirements. Code compliance is complicated by the absence of nationally recognized standards and testing procedures; furthermore, compliance is costly, time consuming, and un- 


\section{BUILDING CODES (Continued)}

certain. Local variations of testing and approval requirements could easily fragment a potential national market. Solutions to remove existing barriers are discussed.

No important legal barriers to SHAC systems have been found in either tort or insurance law. Nor is it recommended that the federal government take any new action at this time with regard to warranties. Present tort law should adequately handle injuries by solar devices.

Insurance will usually reimburse the property owner for any judgements against him and for associated legal fees. Solar homeowners may pay more for insurance if their homes are found to present more risks.

Hirshberg, Alan; Schoen, Richard. "Barriers to the Widespread Utilization of Residential Solar Energy: The Prospects for Solar Energy in the U.S. Housing Industry." Policy Sciences Vol. 5 (No. 4): pp. 453-468; December, 1974.

Available from: Local library.

One major barrier to the widespread adoption of residential solar energy systems is the building industry's resistance to innovation.

Over 3,000 independent code-producing bodies generate diverse codes. Divers1ty results in problems associated with marketing, sales, and service of solar products. The highly leveraged and cyclical nature of the industry creates economic impediments to lowering the greater initial costs of solar energy systems.

Past attempts at introducing Innovation into the building industry show that subsystems and component parts, have been more successfully adopted by the industry than total home construction innovations. 


\section{BUILDING CODES (Continued)}

Kraemer, Sandy F. Solar Law: Present and Future, with Proposed Forms. Colorado Springs, Co: Shepard's Inc.; 1978. $364 \mathrm{p}$.

See SOLAR ACCESS RIGHTS

Nadler, Arnold D. "Planning Aspects of Direct Solar Energy Generation." AIP Journa1 pp. 339-351; October, 1977.

See SOLAR ACCESS RIGHTS

Robbins, Richard L. "Building Codes, Land Use Controls, and other Regulations to Encourage Solar Energy Use." Proceedings of the Consumer Conference on Solar Energy Development: Consumer Conference on Solar Energy Development; October 2-5, 1976; 41 buquerque, NM. Albuquerque, NM: New Mexico Solar Energy Association; 1976. pp. 283-300.

Available from: Local Library; New Mexico Solar Energy Association, P.0. Box 2004, Santa Fe, NM 87501, $\$ 10.64$ (inc. postage).

State and local governments can encourage solar energy use by updating existing building codes, land use controlo, and uther regulations to climinate burriers that are remnants of past regulatory objcctives. Furthermore, governments can protect solar skyspace either by legislation or eminent domain.

A slate agency, established specifically to promote solar energy planning and use, could perform several functions: (1) plan for statewide use of solar energy systems, (2) generate model laws and regulations, (3) admin ister government financing programs, (4) overece community plaunlug activities, and (5) maintain a solar energy central clearinghouse.

Scott, Ronald D. "The United States National Program for the Demonstration of Solar Heating and Cooling in Buildings: Progress Report," in vol. 1 of Sharing the Sun! Solar Technology in the Seventies (pp. 126-141). Proceedings of the Joint Conference of the American Section, International 


\section{BUILDING CODES (Continued)}

Solar Energy Society and Solar Energy Society of Canada, Inc., August 15-20, 1976, Winnipeg. 10 vols. Cape Canaveral, FL: American Section of the International Solar Energy Society; 1976.

Available from: Local library; ISES members: Publishing Office, 205B McDowell Hall, University of Delaware, Newark, DE 1971, $\$ 50.00$ (set); Nonmembers: Pergamon Press, Maxwell House, Fairview Park, Elmsford, NY $10523, \$ 250.00$ (set).

The National Program for the Demonstration of Solar Heating and Cooling of Buildings has identified four primary constraints to the adoption of solar energy. These are: (1) building code and regulatory constraints, (2) lending institution constraints, (3) technology constraints, and (4) marketability constraints.

The overall goal of the National Program is to assist in the establishment of a viable solar industry, to stimulate its growth, and to achieve substantial reduction in fossil fuel consumption. This goal is to be achieved by: (1) stimulating solar energy applications, (2) demonstrating the feasibility of solar heating and cooling of buildings, (3) implementing research, (4) establishing a solar data bank, (5) developing standards, and (6) i.dentifying incentives nẹcessary to eliminate barriers to solar energy use.

Waksman, D. Plan for the Development and Implementation of Standards for Solar Heating and Cooling Applications. Washington, DC: U.S. Department of Commerce; August, 1976.

See STANDARDS 
THIS PAGE INTENTIONALLY LEFT BLANK 
Section 4.0

CONSUMER PROTECTION

AIA Research Corporation. Early Use of Solar Energy in Buildings: A Study of Barriers and Incentives to the Widespread Use of Solar Heating and

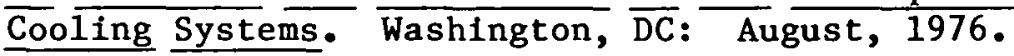

See BUILDING CODES

Bezdek, Roger. "Marketing, Manpower, Consumer, and Environmental Issues," Chapter VII in Analysis of Policy Options for Accelerating Commercialization of Solar Heating and Cooling Systems. Washington, DC: The George Washington University, $1977 . \overline{467} \mathrm{p}$.

See LABOR

Bossong, Ken. "The Case Against Private Utility Involvement in Solar/ Insulation Programs." Washington, DC: Center for Science in the Public Interest, 1977.

See ANTITRUST

Dawson, Richard. "Consumer Protection." Proceedings of the Consumer Conference on Solar. Energy Development: Consumer Conference on. Solar Energy Development; October 2-5, 1976; Albuquerque, NM. Albuquerque, NM: New Mexico Solar Energy Association; 1976. pp. 30-37.

Available from: Local library; New Mexico Solar Energy Association, P.0. Box 2004, Santa Fe, NM 87501, \$10.64 (inc1. postage).

Consumer confidence is growing because of government efforts to protect solar buyers from either fraud or inferior products by doing the following: (1) establishing an information dissemination program, (2) recommending state testing facilities to verify manufacturers' claims, (3) investigating deception schemes, and (4) promoting the adoption of a stringent code of ethics and a self-policing program in the solar energy industry. 


\section{CONSUMER PROTECTION (Continued)}

Kraemer, Sandy F. Solar Law: Present and Future, with Proposed Forms. Colorado Springs, Co: Shepard's Inc.; 1978. 364 p.

See SOLAR ACCESS RIGHTS

Reitze, Arnold W.; Jr.; Prezyna, Ann E. "Utilizing Solar Power - The Institutional Challenges." Environmental Comment.pp. 1-5; April, 1976.

Available from: Local library.

Institutional barriers to the development of solar energy include building codes, fire codes, labor problems, the use of solar power in generating electricity, and the legal right to sunlight. The role of federal and state governments will be to develop tax policies favorable to solar implementation and to provide funding for research and development. Congressional action has already funded solar research through the Solar Heating and Cooling Demonstration Act of 1974, the Solar Energy Research, Develoment, and Demonstration Act of 1974; and the federal Non-Nuclear Research and Development Act of 1974 .

Future ojectives are to stimulate a public market for solar technology and to develop a technology delivery system. The following consumer problems must be addressed: establishment of equipment performance standards, rcduction of the cost of solar devices, resolution of legal problems, development of consumer information programs, and an adequate infrastructure for installation of solar devices. 
Section 5.0

ENVIRONMENTAL ASPECTS

Bezdek; Roger. "Marketing, Manpower, Consumer, and Environmental Issues," Chapter VII in Analysis of Policy Options for Accelerating Commercialization of Solar Heating and Cooling Systems. Washington, DC: The George Washing-

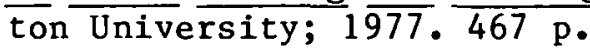

See LABOR

Hillhouse, Karin H. "Solar Energy--Its Environmental Dimensions." Proceedings of the Consumer Conference on Solar Energy Development: Consumer Conference on Solar Energy Development, October 2-5, 1976; Albuquerque, NM. Albuquerque, NM: New Mexico Solar Energy Association; 1976; pp. 38-70.

Available from: Local library; New Mexico Solar Energy Association, P.0. Box 2004, Santa Fe, NM 87501, $\$ 10.64$ (incl. postage).

Increasing consumer acceptance of solar technology requires consideration of the following environmental issues: (1) environmental protection from adverse impacts of solar development, (2) analyses of land use issues prior to adopting a solar rights system, and (3) environmental protection strategies as incentives for solar development. Although the federal government has expressed legislative concern about the possible environmental impacts of solar energy, states have focused instead on developing solar tax incentives because their environmental protection controls are presently sufficient. The prior appropriation doctrine could be applied to protect solar rights; however, land use ramifications of a solar appropriation rights scheme are considerable and could result in frustrating land use objectives. A state public utilities commission has considerable latitude for shaping community and regional growth. Energy mapping and solar land use planning provide effective incentives to promote solar growth. State schemes for instituting solar land use planning are discussed. 


\section{ENVIRONMENTAL ASPECTS (Continued)}

Hughes, Evan E.; Dickson, Edward M.; Schmidt, Richard A. Control of Environmental Impacts from Advanced Energy Sources. Stanford Resarch Institute Project 2714. Washington, DC: U.S. Environmental Protection Agency; 1974.

Available from: Local 1ibrary; GPO, Stock No. 055-001-00966, \$4.00; NTIS, Report No. PB 239450 , PC $\$ 12.00$, MF $\$ 3.00$.

The environmental effects associated with the production of energy through solar (and other) technologies are discussed. Impacts on ai, quality, water quality, and land use are analyzed; and levels of adverse environmental effects are projected.

Although widely reported to be pollution-free, solar energy will have envi ronmental consequences.

Kraemer, Sandy F. Solar Law: Present and Future, with Proposed Forms. Colorado Springs, Co: Shepard's Inc.; 1978. 364 p.

SeE SOLAR ACCESS RIGHTS

Lior, Noam; Lepore, John A.; Shore, Sidney. "Residential Solar Heating Retrofit in the Urban Environment," in vol. 4 of Sharing the Sun! Solar Technology in the Seventies (pp. 36-52). Proceedings of the Joint Confcrence of the Amcrican Section, International sular Eriergy suciely aud Solar Energy Society of Canada, Inc., August 15-20, 1976, Winnipeg. 10 vols. Cape Canaveral, FL: American Section of the International Solar Energy Society; 1976.

Available from: Local library; ISES members: Publishing office, 205B McDowell Hall, University of Delaware, Newark, DE 19711, $\$ 50.00$ (set); Nonmembers: Pergamon Press, Maxwell House, Fairview Park, Elmsford, NY $10523, \$ 250.00$ (set). 


\section{ENVIRONMENTAL ASPECTS (Continued)}

Residential solar retrofit in an urban location faces several problems which are either unique or particularly pronounced in that environment.

Typically, residents who can least afford solar conversion are concentrated in urban residential neighborhoods. Vandalism and theft of outside solar components may present problems. The lack of a legally protected right to receive sunlight is particularly significant in urban settings, where adjacent high-rise construction is a constant threat. Typical urban dwellings have a low roof-to-floor-area ratio; hence, rooftops may provide insufficient space for the installation of the necessary collectors.

The paper includes a detailed description of a row home retrofit project in Philadelphia.

U.S. Department of Housing and Urban Development (HUD), National Bureau of Standards, and U.S. Department of Commerce. Interim Performance Criteria for Solar Heating and Combined Heating/Cooling Systems and Dwellings. Washington, DC: Government Printing Office; 1975.

SEe SOLAR HEATING AND COOLING 
THIS PAGE INTENTIONALLY. LEFT BLANK 


\section{Section 6.0}

FEDERAL LEGISLATION AND PROGRAMS

Arthur D. Little, Inc. Residential Solar Heating and Cooling Constraints and Incentives. A Review of the Literature. Washington, DC: U,S. Department of Housing and Urban Development; 1976 May.

See SOLAR HEATING AND COOLING

Bezdek, Roger. "Regional Aspects of the Incentive Program," Chapter VIII in Analysis of Policy Options for Accelerating Commercialization of Solar Heating and Cooling Systems. Washington, DC: The George Washington University; 1977. $467 \mathrm{p}$.

Available from: Local library; NTIS, Report No. TID-27597, PC \$14.50, MF $\$ 3.00$.

An effective federal solar energy incentives program must take into account regional variations in barriers to solar energy. An inflexible program could result in windfalls for those in regions where barriers are low, and little impact where barriers are high. The necessity of a flexible program is explained, the desirabiity of state cost sharing is discussed, and the idea of solar regional implementation centers is explored.

Cone, B.W. An Analysis of Federal Incentives Used to Stimulate Energy Production. Richland, WA: Battelle Pacific Northwest Laboratories; 1978.

Available from: Local library; NTIS, Report No. PNL-2410 Rev/UC-59; GPO, Stock No. 061-000-00101-8, \$6.00.

An understanding of the complex technological, economic, legal, institutional, and political interrelationships is necessary to design an effective sol.ar energy policy. Moreover; stimulation of solar energy production requires a systematic analysis of past federal incentives used to promote conventional energy resources. Without such analysis, wasted resources and 
FEDERAL LEGISLATION AND PROGRAMS (Continued)

lost federal expenditures would result. This report identifies, quantifies, and analyzes these incentives and relates them to current thought about solar energy.

Research indicates that considerable differences of opinion prevail regarding the economic feasibility of solar energy. Studies also indicate that major areas of legal concerns exist, but new approaches are available to encourage solar energy development. Although a wide variety of fiscal incentives can be used to reduce solar energy costs. institutional forces within the U.S. housing industry must be overcome to achieve acceptance of solar technology.

Ezra, Arthur A. "Technology Utilization: Incentives and Solar Energy." Science. Vol. 187 (No. 4178) pp.707-713; February 18, 1975.

Available from: Local library.

Different incentives initiated by the federal government may be used to stimulate nongovernmental applications of solar research and development. Such incentives include the following: (1) federal procurement of a limited quantity of the product from a private çompany; (2) federally funded demonstration projects to provide empirical data to private companies; (3) information dissemination through publication of performance specifications by the federal National Technical Information Services; (4) outright grants in conjunction with cost-sharing practices; (5) exclusive licenses for federal patents to remove risks of private investment; (6) no-cost leasing of tederal demonstration plants; and ( /) leasing of public lands for the construction of experimental oil shale extraction plants or geothermal power plants. Other incentives include government product and process testing, and loan guarantees in the areas of solar and geothermal energy. These incentives must be coordinated to insure that components of the technology delivery system are appropriately activated. 
FEDERAL LEGISLATION AND PROGRAMS (Continued)

"Fast-growing Solar Industry Has 'Clouds." Industry Week pp. 105-107; April 2, 1978.

Available from: Local library.

Businessmen consider that expansion of the solar industry will only occur if government restraints are decreased and incentives are simultaneously increased. The Carter administration's energy bill is a significant restraint, as are lack of mortgage money, restrictive building codes, and the lack of standards for solar devices. Potential governmental inducements include tax incentives and rebates, financing guarantees, and unified building codes.

Halacy, Dan. "Federal Solar Legislation." Proceedings of the Consumer Conference on Solar Energy Development: Consumer Conference on Solar Energy Development; October 2-5, 1976; Albuquerque, NM. Albuquerque, NM: New Mexico Solar Eneryg Association; 1976. Pp. 253-282;

Available from: Local library; New Mexico Solar Energy Association, P.0. Box 2004 , Santa Fe, NM 87501, $\$ 10.64$ (incl. postage).

An historical overview of the developing interest in federal solar legislation is presented, including general statements about its slow, uneven growth. The following enactments of the 93rd Congress are discussed: (1) the Solar Heating and Cooling Demonstration Act authorizing $\$ 5$ millon to NASA and HUD, plus an additional $\$ 50$ million for actual demonstrations through 1979; (2) the Solar Energy Research, Development, and Demonstration Act calling for a solar energy resource inventory, demonstration of eight solar technologies, establishment of a solar energy data bank and research institute (SERI), (3) the Energy Reorganization Act, establishing the Energy Research and Development Administration, and (4) the Federal Non-Nuclear Energy Research and Development Act establishing a national program for research and development in non-nuclear energy sources. Also discussed are (1) key 1976 bills, (2) growing solar appropriations, and (3) secondary 
FEDERAL LEGISLATION AND PROGRAMS (Continued)

federal impact on solar programs. An appendix of solar and solar-related legislation is provided.

Higgins, James C. "Ocean Thermal Energy Convcrsion Plants: Federal and State Regulatory $\Lambda$ spects," in Ocean Thermal Energy Conversion: Lega1, Political, and Institutional Aspects. Edited by H. Gary Knight, J.D. Nyhart, and Robert E. Stein. Lexington, MA: Lexington Books; 1977. 234 p.

See OCEAN ENERGY

Jones, Nancy Lee. "Solar Rights: The Present Status of Legal Access to Light and Possible Constitutional objections to Federal Legislation." U.S. Library of Congress, Congressional Research Scrvice; Washington, DC: June, 1977.

Available fron: Solar Energy Information Center, Solar Energy Research Institute, 1536 Cole Boulevard, Golden, C0 80401.

The possibility that Congress may take legislative action to create a "solar right" raises two constitutional issues: (1) Does Congress have the power to impose a legal right of access to sunlight on the states? (2) Would such legislation constitute a "taking" of an individual's property requiring compensation?

Congress may derive the power to impose a solar right from the doctrine of tederalism or trom the commerce clause. In each case lie cunsliluliundity of the legislation will depend on the method employed to create the right and the specific language used.

Legislation granting a right of access to sunlight would probably not constitute a "taking" requiring compensation, since no compensation is required for valid police regulations which restrict an owner's property use. The solar right restrictions would neither render the property uninhabitable nor deprive the owner of its complete use or elljoyment. 


\section{FEDERAL LEGISLATION AND PROGRAMS (Continued)}

Magnas, Howard L. Solar Energy Projects of the Federal Government. Washington, DC: U.S. Federal Energy Administration; January, 1975.

Available from: Local library; NTIS, Report No. PB 241620 , PC $\$ 6.25$, MF $\$ 3.00$.

Congress has passed a number of laws aimed at stimulating solar energy growth: (1) the 1974 Solar Heating and Cooling (SHAC) Demonstration Act is designed to demonstrate the economic and mechanical efficiency of SHAC systems and components; (2) the 1974 Energy Reorganization Act establishes the Energy Research and Development Administration (ERDA) with broad authority over all aspects of federal energy-related functions; (3) the 1974 Solar Energy Research, Development, and Demonstration Act establishes a task force to set solar energy research priorities; (4) the 1974 Federal NonNuclear Energy Research and Development Act incorporates many functions of early laws into a comprehensive research and development program within ERDA; and (5) the 1974 Housing and Community Development Act gives the Secretary of Housing and Urban Development the authority to sponsor demonstrations of SHAC in residential buildings. This report provides an overview and analysis of the resulting solar energy projects, the amount of funding, and the major program areas.

Maize, Kennedy P. "A Look at the Sunny Side: Government R\&D Programs." Environmental Action. Vo1. 8.(No. 21) pp. 4-8; March 12, 1977.

Available from: Local library.

The U.S. Energy Research and Development Administration fostered solar energy development. Congressional prodding forced ERDA to overcome 1ts initial bias toward nuclear energy and adopt a commitment to solar energy.

ERDA's most visible solar programs focus on residential heating and cooling, with cmphaeis on practical demonstrations rather than on high technology. 


\section{FEDERAL LEGISLATION AND PROGRAMS (Continued)}

Critics complain, however, that ERDA's insistence on unnecessarily high equipment specifications and standards keeps system prices high and creates barriers for small inventors and do-it-yourselfers.

Mills, Jon, and R.D. Woodson. "Energy Policy: A Test for Federalism." Arizona Law Review. Vol. 18 (No. 2) pp. 405-451; 1976.

Available from: Local library.

Federal and state governments interact to determine energy policy. Powers constitutionally delegated to the federal government affecting energy policy include the spending and taxing powers, commerce power, and war power. State energy legislation is based on the implicit police power.

In the development of traditional energy sources, a major conflict exists between federal needs for an adequate energy supply and state environmental concerns. The development of alternative energy supplies from snlar, geothermal, and wind energy and solid waste wi11. provide opportunities for federal-state cooperation in the areas of providing tax incentives, financing research and development, and establishing legal rights to the energy source. Federal authority will preempt state jurisdiction in the generation and distribution of electricity; however, states will maintain authority to address energy conversion problems. Overlapping jurisdictions regarding building construction and private and commercial transportation allow tor tederal-state coordination of energy conservation. Fpdpral agencies will continue to control certain phases of energy development, including the overall development framework, items passing in interstate commerce, and energy for national security. State governments will control zoning, building codes, and utility regulation. 
Moore, J. Glen. "Solar Energy Legislation in the 95th Congress: January through August 1977." U.S. Library of Congress, Congressional Research Service; Washington, DC: September 6, 1977. (Updated through November i977.)

Available from: Solar Energy Information Center, Solar Energy Research Institute, 1536 Cole Boulevard, Golden, CO 80401.

The Congress dealt with á wide variety of solar-related bills in 1977. Chief among them were: a Small Business Loan Program for companies working in solar and energy conversion; the International Development and Food Assistance Act, which promotes cooperative energy research and development programs with developing countries; a study to determine the feasibility of installing solar energy equipment in House office buildings; the Agriculture Act of 1977, which contains provisions for promoting solar energy use on American farms; and the Educational and Health Care Facilities Efficiency Act of 1977, which authorizes matching federal grants for schools and hospitals which install solar heating/cooling systems. The National Energy Act, passed by the House on August 5, 1977, contains several solar-related provisions including tax credits for residential solar and wind energy equipment and federal demonstration programs. Both the House and the Senate approved appropriations of $\$ 368.25$ million for solar programs in ERDA, and a fiscal year 1978 authorization bill for $\$ 384$ million passed the Senate.

Other measures considered include: bills dealing with tax credits, deductions, and abatements; bills to increase assistance under certain federal housing programs to cover solar costs; loan guarantee programs for new energy technologies; grants to states for solar applications; bills to promote solar use in federal buildings; antitrust bills; bills to promote international cooperation in solar energy applications; "sun rights" bills; and bills to encourage state and local governments not to tax solar property. 


\section{FEDERAL LEGISLATION AND PROGRAMS (Continued)}

Naef, Frederick E. "Economic Aspects of Ocean Thermal Energy Conversion," in vo1. 5 of Sharing the Sun! Solar Technology in the Seventies (pp. 392411). Proceedings of the Joint Conference of the American Section, International Solar Energy Society and Solar Energy Society of Canada, Inc., August 15-20, 1976, Winnipeg. 10 vols. Cape Canaveral, FL: American Section of the International Solar Energy Society; 1976.

See OCEAN ENERGY

Nyhart, J.D. "Problems of Legal Responsibility and Liability to be Anticipated in OTEC Operations," in Ocean Thermal Energy Conversion: Legal, Political, and Institutional Aspects. Edited by H. Gary Knight, J.D. Nyhart, and Robert E. Stein. Lexington, MA.: Lexington Books; 1977. 243 p.

See OCEAN ENERGY

U.S. Congress. House. Committee on Science and Technology. Solar Energy Legislation Through the 94 th Congress. U.S. Library of Congress, Congressiona1 Research Service, Science Policy Research Division; Washington, DC: Government Printing Office; 1976.

Available trom: Local Library; GrU, stock No. b2-U/U-U4U14-y, \$1L.bU.

This report presents a detailed history of congressional actions in solar energy from the earliest identifiable bills through the 94th Congress. For each solar bill, the compilation includes a brief digest with a legislative history, the full text of the bill, pertinent matter from the Congressional Record, committee reports, and as full a legislative record as possible on the solar aspect of the bills.

An introductory report highlights legislative accomplishments in solar energy and discusses the historical precedents for current solar energy policy. 


\section{FEDERAL LEGISLATION AND PROGRAMS (Continued)}

The compilation is divided into the following subject areas: (I) tax credits, deductions, and abatements, (2) other solar-related tax bills, (3) low-interest loans, (4) other solar-related loans, (5) loan guarantees, (6) grants, (7) antitrust, (8) small business, (9) "sun rights," and (10) agency authority.

U.S. Congress. House. Subcommittee on Energy Research, Development, and Demonstration of the Committee on Science and Technology. A Guide to Federal Programs of Possible Assistance to the Solar Energy Community. U.S. Library of Congress, Congressional Research Service, Science Policy Research Division; Washington, DC: Government Printing office; 1977.

Available from: Local 1ibrary; GPO Stock No. 052-070-04080-7, \$4.00.

This is a guide to existing federal programs that may assist individuals and organizations interested in the applications or advancement of solar conversion technology. It identifies a variety of informational and financial assistance programs available through 21 agencies of the federal government through February 1977.

Thirteen agencies offer some form of informational assistance, and six agencies (the Farmers Home Administration, the Rural Electrification Administration, the Economic Development Administration, the Office of Minority Business. Enterprise, the Farm Credit Administration, and the Small Business Administration) offer some form of financial aesictance.

U.S. Congress. Joint Economic Committee. The Economics of Solar Energy. Hearing . . , 94th Congress, 2nd Session, 1976.

Available from: Local 1ibrary; GPO, Stock No. 052-070-03979-5,\$.85. 


\section{FEDERAL LEGISLATION AND PROGRAMS (Continued)}

Testimony given on Senate Bill 3227--The Solar Energy Act of 1976--by various experts from both government and industry, generally concluded that solar energy is technically and economically feasible now and that a greater level of government support of research and development is necessary.

Reports of witnesses and submissions for the record were given to the Joint Economic Committee on April 5, 1976.

Witnesses from the private sector testify on the development potential of solar energy programs prior to consideration of appropriations for those programs .

U.S. Congress. Senate. Select Committee on Small Businesses. Energy Research and Development and Small Business. Hearings . . , 94 th Congress, lst Session, 1975.

Available from: Local library; GPO: lst session, pt. 1, Stock No. 052-070-03108-5, \$6.60; 1st Session, pt. 1A, Stock No. 052-070-03107-7, $\$ 6,20$; 1st Session, pt. 1B, Stock No. 052-070-03109-3; lst Session, pt. 1C, Stock No. 052-070-03110-7, \$10.25; Ist Session, pt. 1D, Stock No. 052-070$03111-5, \$ 5.85$.

A transcript of hearings before the Scnatc Sclect Comittee on Small Business on May 13 and 14, 1975. The Committee discussed the development of solar energy in the United States and what part small business can play in this development.

The hearings contain considerable solar energy data from private corporations and government agencies, as well as descriptions of National Science Foundation programs in solar technology development. 
FEDERAL LEGISLATION AND PROGRAMS (Continued)

U.S. Energy Research and Development Administration. Division of Solar Energy. National Program for Solar Heating and Cooling (Residential and Commercial Applications). Washington, DC; 1975 October.

Available from: Local library; NTIS, Report No. ERDA-23A, PC $\$ 6.00$; MF $\$ 3.00$.

This Interagency Task Force report reviews the federal planning effort for solar heating and cooling systems utilization. Subjects exarnined include the following: the goals and objectives of the federal program, constraints to widespread solar utilization, strategy for implementation, residential and commercial demonstrations, research and development, collection and dissemination of information, additional policy measures to promote widespread utilization (e.g., federal assistance in removing legal barriers), and management of the program.

The goal of the federal program is to stimulate industrial and comnercial activity in production and distribution of solar heating and cooling systems, thereby reducing the demand on present fuel supplies through utilization of these systems in residential and commercial buildings.

U.S. Federal Energy Administration. Project Independence Blueprint: Final Task Force Report, Solar Energy. Waghington, DC: Covcrnment Printing Office; 1974.

Available from: Local 1ibrary; GPO, Stock No. 041-018-00012-7, \$6.20.

This is a study of the potential production capabilities of the solar energy. industry to the year 2000. The six solar types studied (solar heating and cooling of buildings, solar thermal conversion, wind energy conversion, bioconversion to fuels, ocean thermal energy conversion, and photovoltaic electric power systems) are analyzed for (1) economic viability, (2) resource availability and the construction materials necessary for utiliza- 


\section{FEDERAL LEGISLATION AND PROGRAMS (Continued)}

tion, (3) for utilization environmental impact, (4) required capital investment, and (5) research and development strategy.

The systems are projected according to a "business-as-usual" standard, which assumes little federal involvement, and an "accelerated development" standard, which assumes a larger federal involvement through tax, loan, and depreciation policies favorable to solar unit installation.

Although energy development potential varies with each resource, all solar resources are expected to be economically viable by 1990 .

Zillman, Donald N.; and Deeny Raymond. "Legal $\Lambda$ spects of Solar Energy Development." Arizona State University Law Journal. Vol. 1976 (No. 1): pp. 25-58; 1976 .

ScC LAND USE 
Section 7.0

FINANCING / INSURANCE

Barrett, David; Epstein, Peter; Haar, Charles M. Financing the Solar Home. Lexington, MA: Lexington Books; 1977.

Available from: Local library; Lexington Books, 125 Spring St., Lexington, MA $02173, \$ 18.00$.

This book compiles the results of interviews of officers of savings and loan associations, mutual savings banks, commercial banks, life insurance companies, and mortgage companies. The type of financing a homeowner or contractor receives determines the total cost of the solar device. Primary lender concerns include marketability and value, reliability and performance, the backup system and ease of conversion, first costs and projected utility savings, payback period and life-cycle cost estimates, manufacturer's reputation, the lender's liability, legal uncertainties, and the insurability of the home. Single-family homeowners will be more successful in obtaining private financing for solar innovations than will multi-family income properties. According to lenders, financial risks associated with innovations should be taken by those who have a cushion of financial resources. Mortgage insurers and secondary market entities take a conservative, though not negative, stance regarding solar installations.

Lenders' receptivity to solar systems may be increased by insurance programs for conversion (covering the cost of converting from solar energy back to a traditional heating system) or the top part of the risk on solar loans. The PITI (principal, interest, taxes, insurance) formula for computing loans could be changed to include energy: PITI + E. Government mortgage insurance ceilings could be raised to cover solar installations.

Ben-David, Shaul, et al. "Near-Term Prospects for Solar Energy: An Economic Analysis." Natural Resources Journal. Vol. 17 (No. 2) pp. 169-207; Apri1, 1977. 


\section{FINANCING/INSURANCE（Continued）}

Available from: Local library.

Assuming energy price decontrols, widespread residential use of solar energy is feasible by 1980. Solar development feasibility is greatest in the northern United States due to higher alternative energy prices and larger heating loads. Retrofit space and water heating is price-competitive with new home installations and is more easily financed. Because solar energy costs are capital costs (the fuel is free), interest rates are critical factor in determining feasibility.

Bezdek, Roger. "Economic and Financial Incentives," Chapter II in Analysis of Policy Options for Accelerating Commercialization of Solar Heating and Cooling Systems. Washington, DC: The George Washington University; $19 \overline{77 .}$ 467 p.

Available from: Local library; NTIS, Report No. TID-27597, PC \$14.50, MF $\$ 3.00$.

A wide variety of cconomic and financial incentives are available to encourage the use of SHAC systens. The following 14 representative types of incentives were selected for consideration: (1) grants and subsidies, (2) income tax credits, (3) income tax deduction, (4) federal compensation for state and local property and sales taxes, (5) low-cost interest loans, (6) guaranteed loans, (7) accelerated depreciation/rapid amortization, government insurance and reinsurance, (9) government procurement, (10) demonstration programs, (ì) government equity investment, (12) tax-exempt bonds, (13) government incentives for utilities, and (14) deregulation of oil and gas on a fuel tax.

A quantitative analysis of the impacts of the major financial incentives is provided according to the following nine criteria: (1) equity, (2) Leverage, (3) administrative efficiency, (4) government costs, (5) facilitation of innovation, (6) market penetration, (7) continuity of effect, (8) effect on the economy, and (9) other social effects. 


\section{FINANCING/INSURANCE (Continued)}

The Solar Technology Delivery System is discussed as a useful conceptual framework for guiding the formulation of federal strategies and incentives for achieving the goal of a self-sustaining and expanding nonfederal market for SHAC systems.

Quantitative cost/benefit estimates are derived for several financial incentives, and a summary of state solar energy legislation (as of early spring 1977) is provided.

Bezdek, Roger. "Legal and Regulatory Issues." Chapter IV in Analysis of Policy Options for Accelerating Commercialization of Solar Heating and Cooling Systems. Washington, DC: The George Washington University; 1977. 467 p.

See LAND USE

Blair, John F., Jr.; O'Brien, Josephine. "Some Institutional Problems of Residental Solar Heating," in vol. 9 of Sharing the Sun! Solar Technology in the Seventies (pp. 190-199). Proceedings of the Joint Conference of the American Section, International Solar Energy Society and Solar Energy Society of Canada, Inc., August 15-20, 1976, Winnipeg. 10 vols. Cape Canavera1, FL: American Section of the International Solar Energy Society; 1976.

Available from: Local library; ISES members: Publishing office, 205B McDowe11 Hall, University of Delaware, Newark, DE 19711, $\$ 50.00$ (set); Nonmembers: Pergatuon Press, Maxwell House, Fairview Park, Elmsford, NY $10523, \$ 250.00$ (set).

Since financial institutions have an overwhelming influence on the building industry and market, strong governmental actions are needed before there can be widespread adoption of solar technology for home heating.

The government can foster solar implementation through (1) various subsidy programs, (2) utility-rate structure modification, and (3) adoption of a credible and consistent energy policy. 


\section{FINANCING/INSURANCE（Continued）}

Booz-Allen and Hamilton, Inc. The Effectiveness of Solar Energy Incentives at the State and Local Leve1. Washington, DC: U.S. Federal Energy Administration; March, 1976.

Available from: Local library; NTIS, Report No. PB 263371 , PC \$5.00, MF $\$ 3.00$.

Numerous federal, state, and local regulations and laws provide both potential obstacles and possible incentive opportunities for the diffusion of solar energy. The majority of these laws are land-use related. An overview of potential, proposed, and enacted state and local actions to encourage solar heating and cooling reveals that property and sales tax exemptions have received the most attention.

Tax inducements are attractive governmental incentives because the administrative structure already exists, and the potential recipients are familiar with the tax machinery. Other tax-related incentives include personal and corporate income tax deductions, tax credits, accelerated depreciation of solar equipment, and investment tax credits.

The government can provide low-cost loans and loan guarantees to ensure that the costs of financing solar equipment remain low.

Various utility company policies that would affect solar energy development arc (1) rate restructuring, (2) utility ownership of solar equipment, and (3) gas utility easement of supply curtailments for solar users.

Other possible incentives include grant and subsidy programs, government insurance, government procurement, demonstration programs, research and development programs, and information programs. 
FINANCING/INSURANCE (Continued)

Carlson, R.C. "Solar Energy: Has the Time Come?" Proceedings of the Consumer Conference on Solar Energy Development: Consumer Conference on Solar Energy Development; October 2-5, 1976; Albuquerque, NM. Albuquerque, NM: New Mexico Solar Energy Association; 1976. pp. 76-87.

Available from: Local library; New Mexico Solar Energy Association, P.0. Box 2003, Santa Fe, NM. 87501, $\$ 10.64$ (incl. postage).

The immediate prospects for solar energy are determined by past and present subsidies for nonsolar energy resources. Although the time of solar energy has come, its progress will be impeded unless the federal government enacts subsidies to make solar energy competitive with conventional sources. Solar subsidies, however, face sociopolitical and energy conservation problems.

Damon, Peter S. "Financing Solar Systems Costs." Proceedings of the Consumer Conference on Solar Energy Development: Consumer Conference on Solar Energy Dvelopment; October 2-5, 1976; Albuquerque, NM. Albuquerque, NM: New Mexico Solar Energy Association; 1976. pp. 181-190.

Available from: Local library; New Mexico Solar Energy Association, P. 0. Box 2003, Santa Fe, NM 87501, \$10.64 (incl. postage).

Increasing awareness of the indirect impact of fossil fuel shortage on the value of loan portfolios will provide economic motivation for lenders to increase financing of solar loans. From the lender's point of view, a solar heating system which increases the loan-to-market value ratio of a loan on a residence is an unattractive investment. An increase in market value of a residence improves the ratio, as well as the feasibility of solar loans. An increased social value placed on energy consersation could increase residential market values.

Fannin, Paul, "Solar Energy: Overcoming the Barriers." Arizona Business. Vo1. 23 (No. 7) pp. 3-9; August-September, 1976. 


\section{FINANCING/INSURANCE (Continued)}

Available from: Local library.

Alternative forms of energy development may be obstructed by economic, legal, sociological, and environmental barriers.

The capital intensive nature of solar technology is an economic barrier which may be overcome by federal allocation of funds to government agencies and private utilitice. Technological development will reduce market pricec of solar devices. Consideration of life-cycle costs may make solar cnergy sompetitively priced.

Incentives to solar development include federal and state tax credits for homeowners and businesses, as well as investment capital made available to small businesses and other solar users by lending institutions. Government agencies may implement mortgage procedures which encourage installation of solar units.

Feldman, Stephen L.; Anderson, Bruce. "Financial Incentives for the Adoption of Solar Energy Design: Peak-Load Pricing of Back-Up Systems." Solar Energy. Vol. 17 (No. 6) pp. 339-343; 1975.

Soo UTILITIES

Hirshberg, Alan S. "Public Policy for Solar Heating and Cooling." Bulletin of the Atomic Scientists. Vol. 32 (No. 8) pp. 37-45; October, 1976.

Available from: Loca1 library,

Numerous barriers to the widespread adoption of residential solar energy systems exist in the building industry. The craft-based, traditional culture of the construction industry resists innovation. Specification- 


\section{FINANCING/INSURANCE (Continued)}

oriented building codes discourage new construction materials and methods. Mortgage money for the higher initial cost of solar energy construction is scarce.

Certain public policies may speed the implementation of residential solar energy. Several economic policies could hasten the adoption of solar energy, such as deregulation of gas, marginal cost pricing by utilities, mandatory life-cycle cost analysis comparison between conventional and solar systems, and utility ownership and maintenance of solar equipment. Direct cost-reducing policies, such as tax incentives and low interest loans, are other alternatives. None of these alternatives is without some disadvantage or political opposition.

Financial inducements must be tested to determine (1) the appropriate incentive level and (2) the resulting impact. A politically acceptable incentive package must effectively reduce both system cost and fossil fuel consumption.

Hyatt, Sherry V. "Thermal Efficiency and Taxes: The Residential Energy Conservation Tax Credit." Harvard Journal of Legislation. Vol. 14 pp. 281-326; 1977 .

Available from: Local 11brary.

Governmental energy conservation incentives should focus on direct assistance programs rather than on subsidies or indirect tax credits.

Subsidies encouraging homeowners to retrofit their residences face several barriers. Insufficient knowledge of retrofit options, as we11 as consumer apathy and inertia, will result in a low level of participation. High threshold costs must be lowered before subsidies will appear attractive. 


\section{FINANCING/INSURANCE (Continued)}

Studies of large-scale energy-saving conversions are inconclusive as to cost-effectiveness, rendering expensive subsidy programs a questionable inves tment.

Tax credits are equally unacceptable incentives to homeowner retrofit. Tax credits cannot be considered different from other government expenditures; their cost-effectiveness is yet to be proven. Tax credits would result in inequitable and inefficient distribution. The middle classes, who least " need incentives, would receive a windfall, while the poor and nontaxpaying classes would be excluded. Administration of tax credit incentives would create a supervisory burden for the Internal Revenue Service.

A direct expenditure program to encourage homeowner retrofit would allow for flexible administration and more equitable case-by-case decision making. A direct expenditure program would avoid problems of tax inequity and would be less burdensome to adminster than either subsidies or tax credits.

Kraemer, Sandy F. Solar Law: Present and Future, with Proposed Forms. Colorado Springs, CO: Shepard's Inc.; 1978, $364 \mathrm{p}$.

SEe SOLAR ACCESS RICHTS

Moore, J. Glen. "Solar Energy Legislation in the 95th Congress: January through August 1977." U.S. Library of Congress, Congressional Research Service; Washington, DC: September 6, 1977. (Updated through November 1977.)

See FEDERAL LEGISLATION AND PROGRAMS

Nadler, Arnold D. "Planning Aspects of Direct Sular Energy Generation." AIP Journa1. PP. 339-351; October, 1977.

See SOLAR ACCESS RIGHTS 


\section{FINANCING/INSURANCE (Continued)}

Reismeyer, Frederick H.; Solomon, Lewis D. "The Development of Alternative Energy Sources: A Legal and Policy Analysis." Oklahoma Law Review. Vo1. 30: pp. 319-33; Spring, 1977.

Available from: Local library.

The U.S. goal of energy independence will not be achieved unless the federal government helps finance the private sector's efforts to meet the large capital requirements of developing alternative energy sources.

Several federal approaches are available: (1) free market approach, which relies on tax incentives to support research and development, and (2) government financing through grants and seed money, 1oans, and loan guarantees.

A preliminary assessment of alternative energy sources in terms of (1) cost, (2) practicality of implementation, (3) environmental and safety factors, and (4) social considerations suggest that solar and wind power are the most promising. However, the absence of a federally centralized planning and coordinating body for energy policy will impede energy development.

Riggs, John H. "Legal Aspects of Financing Ocean Thermal Energy Plants," in Occan Thermal Energy Conversion: Legal, Political, and Institutional Aspects. Edited by H. Gary Knight, J.D. Nyhart, and Robet E. Ste1n. Lexington, MA: Lexington Books, 1977. 243 p.

See OCEAN ENERGY

Smith, A.E. "Snlar Energy Application Considerations for Housing in Depressed Communities," in vol. 9 of Sharing the Sun! Solar Technology in the Seventies (pp. 137-154). Proceedings of the Joint Conference of the American Section, International Solar Energy Society and Solar Energy Society of Canada, Inc., August 15-20, 1976, Winnipeg. 10 vols. Cape Canaveral, FL: American Section of the International Solar Energy Society; 1976. 


\section{FINANCING/INSURANCE (Continued)}

Available from: Local library; ISES members; Publishing office, 205B McDowell Hall, University of Delaware, Newark, DE 19711, $\$ 50.00$ (set); Nonmembers: Pergamon Press, Maxwe11 House, Fairview Park, E1msford, NY $10523, \$ 250.00$ (set).

Accelerated implementation of solar home heating is needed immediately in economically depressed communities. A study of energy consumption patterns of the poor reveals that rising energy costs have a disproportionately high and severe impact on the poor.

The paper concludes with nine recommendations designed ton rhannel the benetits and cost savings of solar home heating to the poorer sector of the economy.

U.S. Congress. House. Committee on Banking, Currency, and Housing. Low-Interest Loans for Residential Solar Heating and Cooling Equipment. Hearings before the Subcommittee on Housing and Community Development on H.R, 3849, H.R. 8524, 94th Congrece, lot Ecssion, 1975.

Available from: Local library; GPO, Class No. Y4.B22/1:504, Item 1013.

Testinony by various representatives of government, industry, and acadenia was given on H.R. 3849 and H.R. 8524. These two bills were designed primarily to institute financial incentivec for the installation or solar heating and conling equipment in residentinl buildings.

A research project undertaken to study lending institution behavior and attitudes regarding solar homes concludes that financiers generally respnnd positively to lending requests for solar-equipped homes.

U.S. Congress. House. Committee on Science and Technology. Solar Energy Legislation Through the $94 \mathrm{th}$ Congress. U.S. Library of Congress, Congressional Research Service, Science Policy Research Division, Washington, DC: Government Printing office; 1976.

See FEDERAL LEGISLATION AND PROGRAMS 


\section{FINANCING/INSURANCE (Continued)}

U.S. Congress. House. Subcommittee on Energy Research, Development, and Demonstration of the Committee on Science and Technology. A Guide to Federal Programs of Possible Assistance to the Solar Energy Community. U.S. Library of Congress, Congressional Research Service, Science Policy Research Division, Washington, DC: Government Printing office; 1977.

See FEDERAL LEGISLATION AND PROGRAMS 
THIS PAGE INTENTIONALLY LEFT BLANK 
Section 8.0

INTERNATIONAL LAW

Bury v. Pope, 1 Cro. Eliz. 118, 78 Eng. Rep. 375 (Exc. 1586).

Available from: Local Law 1ibrary.

An action by plaintiff houseowner against an adjoining houseowner for obstruction of light. Plaintiff had enjoyed an unobstructed view for over 30 years before defendant's erection of a house on defendant's land blocked the light going to plaintiff's windows. Held: A landowner gains no cause of action against an adjoining landowner who, building upon his own land, obstructs the light that naturally falls upon the adjoining landowner's house. For defendant.

Caruso, Lawrence R.; Caruso, Linda. "International Cooperation in the Production of Solar Energy through the Use of Satellites." Lawyer of the Americas (University of Miami Journal of International Law). Vol. 9 (No. 3) Pp. 540-544; Fall, 1977.

Available from: Local libraries.

Solar energy may be collected on satellites in synchronous orbit and relayed back to earth where it can be allocated under treaties, United Nations resolutions, and international law. In the developmental states of solar space technology, bilateral arrangemetns will suffice; as the technology advances, international treaties may be necessary.

Charles Semon and Co. Ltd. v. Bradford Corp., 2 Ch. 737 (1922).

Available from: Local law library.

Plaintiffs sought an injunction to restrain the erection of defendant's proposed huilding, alleging that the building would obstruct direct light to their windows and negatively affect the beneficial use of their business 


\section{INTERNATIONAL LAW (Continued)}

premises. Prior to the lawsuit, plaintiffs had enjoyed nearly 20 years of uninterrupted light. HELD: Although construction of defendant's building would cause a significant reduction of direct light to plaintiffs' windows, sufficient light would remain for the benefical use and occupation of the business premises. Because plaintiffs could not show that the reduction in light would bring the remaining light below a judicially recognizable standard, no actionable nuisance was proved. Tnjuction denied.

Chatel, Bertrand. "Some Solar Energy Programmes of the United Nations System," in vol. 1 of Sharing the Sun! Solar Technology in the Seventies (pp. 30-36). Proceedings of the Joint Conference of the American Section, International Solar Energy Society and Solar Energy Society of Canada, Inr., August 15-20, 1976, Winnipeg. 10 vols. Cape Canaveral, -FL: American Section of the International Solar Energy Society; 1976.

Available from: Loca1 library; ISES members: Publishing office, 205B McDowell Hall, University of Delaware, Newark, DE $19711, \$ 50.00$ (set); Nonmembers: Yergamon Press, Maxwe 11 Honse, Fairview Park, Elmıford, NY 10523 , $\$ 250.00$ (set).

Recognizing that solar energy development has particular relevance to the needs and resources of developing countries, numerous United Nations agencies have instituted programs and activities to promote worldwite snlar energy development. The various regional and global programs include educational and advisory services, surveys of solar applications, sponsorship of symposia and conferences, creation of energy centers, studies of financial problems, and encouragement of developing nations to rnnsider alternative energy sources.

Colls v. Home and Colonial Stores Ltd., H.L(E) 179 (1904).

Available from: Local law library. 


\section{INTERNATIONAL LAW (Continued)}

Plaintiffs brought an action for an injunction against the proposed construction of a building that would reduce plaintiffs' access to light. HELD: To constitute an infringement of the right to light there must be what amounts to a nuisance, a real injury. Such injury must be enough to make the house uncomfortable and to prevent the business from being carried on as beneficially as before.

Foster, Harold D.; Sewe11, W.R. Derrick. "Daedalophobia: Diagnosis and Prognosis," in vol. 9 of Sharing the Sun! Solar Technology in the Seventies (pp. 83-90). Proceedings of the Joint Conference of the American Section, International Solar Energy Society and Solar Energy Society of Canada, Inc., August 15-20, 1976, Winnipeg. 10 vols. Cape Canaveral, FL: American Section of the International Solar Energy Society, 1976.

Available from: Local library; ISES members: Publishing office, 205B McDowe11 Ha11, University of Delaware, Newark, DE 19711, $\$ 50.00$ (set); Nonmembers: Pergamon Press, Maxwell House, Fairview Park, Elmsford, NY $10523 \$ 250.00$ (set).

Despite its obvious advantages, solar space heating has not achieved widespread adoption in Canada. Fear of the sun's energy (Daedalophobia) is the major cause. Daedalophobia results in the following: (1) unrealistically low solar research and development budgets, (2) a maze of codes and regulations, (3) undercapitalization of manufacturing efforts, and (4) unwillingness of lle building industry to takc ncccocary rikks.

Great Britain. Laws, Statutes, etc. Rights of Light Act. $7 \& 8$ Eliz. 2, C.56, S 3 .

Available from: Local law library.

The English Rights of Light Act provides for adjudication of access to light rights prior to erection of light-obstructing structures. The Act (1) 


\section{INTERNATIONAL LAW (Continued)}

temporarily extends the period by which uninterrupted access to light matures into a protected right from 20 to 27 years and (2) provides that in order to prevent the running of this access period, a landowner may give notice by application to the local authority stating that the notice is intended to be the equivalent of an obstruction of the access of light.

A2

Greene, W.A. "Easement of Light." New Law Journal, pp. 143-145; February 5,1976 .

Available from: Local library.

A discussion of the articles "Rights of Light" and "Right to Light" by this author.

A2a

Greene, W. A. "Rights of Light." The Law Journal. Vol. 110: pp. 362-363; June $3,1976$.

Available from: Local library.

The English Rights of Light Act (1959) increased the time required for prescription from 20 to 27 years and allowed for registration in lieu of the erection of a screen to prevent the prescriptive acquisition of an easement of 1ight. Purchasers of land should have dominant and servient estates searched for easements to light. Written agreements may be made between the dominant and servient owners to prevent the acquisition of prescriptive rights.

$\mathrm{A} 2 \mathrm{~b}$

Greene, W.A. "Right to Light." The Solicitor's Journal. Vo1. 112 pp. 576-578; Ju1y 19, 1968.

Available from: Local library. 


\section{INTERNATIONAL LAW (Continued)}

The English right to light is determined "according to the ordinary notions of mankind." These notions change over time. To be actionable, an infringement of light must have caused a substantial diminution of light, measured in terms of the quantum of light which is left, not the quantum taken away.

Hallberg, C.R., "International Regulatory Authority Concerning Ocean Thermal Energy Conversion Devices." in Ocean Thermal Energy Conversion: Legal, Political, and Institutional Aspects. Edited by H. Gary Knight, J.D. Nyhart, and Robert E. Stein. Lexington, MA: Lexington Books; 1977. 243 p.

See OCEAN ENERGY

Herwig, Lloyd 0.; Yim, Herbert C. "Report on United States Internationa1 Cooperation in Solar Energy Technology Development," in vol. 9 of Sharing the Sun! Solar Technology in the Seventies (pp. 212-228). Proceedings of the Joint Conference of the American Section, International Solar Energy Society and Solar Energy Society of Canada, Inc., August 15-20, 1976, Winnipeg. 10 vols. Cape Canaveral, FL: American Section of the International Solar Energy Society; 1976.

Available from: Local library; ISES members: Publishing office, 205B McDowe11 Hall, University of Delaware, Newark, DE 19711, \$50.00 (set); Nonmembers: Pergamon Press, Maxwell House, Fairview Park, Elmsford, NY 10523 , $\$ 250.00$ (set).

United States participation in international cooperation in the solar energy field enhances the solar energy effort by inceasing our technology base and expertise, reducing research and development financial burdens, and accelerating technical progress. The United States participates in two multilateral solar energy pacts, the International Energy Agency (IEA) and the NATO Committee on the Challenges of Modern Society (CCMS). The United States also maintains bilateral solar energy exchange agreements with five countries (the U.S.S.R., Japan, France, Spain, and India).

The multilateral agreements allow preliminary visit and information exchanges for purposes of evaluating potential mutual gains from cooperative 


\section{INTERNATIONAL LAW (Continued)}

efforts. Projected research under the IEA include U.S.-1ed "working parties" on development of an Insolation Instrumentation Package and research on Ocean Thermal Gradients. The CCMS work concentrates on exchange of information on solar heating and cooling of buildings. The bilateral agreements have included exchanges of written reports, visits to solar energy facilities, and joint seminars.

Hollick, Ann L. "International Political Implications of Ocean Thermal Energy Conversion Sygtems," in Oeean Thermal Energy Conversion: Legal, Political, and Institutional Aspects. Edited by H. Gary Knight, J.D. Nyhart, and Robert E. Stein. Lexington, MA: Lexington Books; 1977. 243 p.

See OCEAN ENERGY

Knight, H. Gary. "International Jurisdictional Issues Involving OTEC Installations," in Ocean Thermal Energy Conversion: Legal, Political, and Institutional Aspects. Edited by H. Gary Knight, J.D. Nyhart, and Robert E. Stcin. Lexington, MA: Lexington Books; 1977. 243 p.

See OCEAN ENERGY

Mayo, Louis H. Legal-Institutional Arrangements Facilitating Offshore Wind Energy Conversion Systems (WECS) Utilization (Final Report). Washington, DC: George Washington University; September, 1977; DOE/NSF/19137-77/3. 93 p.

See WIND RESOURCES

Moorc, J. Clcn. "Solar Energy Legislation in the 95 th Congress: January through August 1977." U.S. Library of Congress. Congressional Research Service; Washington, DC: September 6, 1977. (Updated through November 1977.)

See FEDERAL LEGISLATION AND PROGRAMS 


\section{INTERNATIONAL LAW (Continued)}

"Urban Problems: Right to Sunlight." The Japan Economic Journal. p. 20; March 5, 1974.

Available from: Local library.

Japan has seen a dramatic increase in the number of complaints filed with local governments concerning citizens' rights to sunlight. These complaints arise in the context of existing regulations and include (1) maximum permissible height restrictions, (2) division of cities into specified categories for planning purposes, and (3) rules defining construction agreements negotiated between landowners and users.

Local governments and the Construction Council have been active in establishing guidelines and providing recommendations för the protection of residential areas from sunlight deprivation.

Washom, Byron. "Spatial and Emerging Use Conflicts of Ocean Space," in Ocean Therma1 Energy Conversion: Legal, Political and Institutiona1 Aspects. Edited by H. Gary Knight, J.D. Nyhart, and Robert E. Stein. Lexington, MA: Lexington Books; 1977.

See OCEAN ENERGY

Wilkinson, H.W. "Let There Be More Light." The New Law Journal. Vol. 118 pp. 7-8; January 4, 1978.

Available from: Local law 1ibrary.

The right to receive a sufficient amount of light is well established in English law.

Courts use various tests to determine what constitutes a sufficient amount of light, including (1) the $45^{\circ}$ rule (where light cannot enter a window at less than $45^{\circ}$, an objection can be made to the offending obstruction), (2) 


\section{INTERNATIONAL LAW (Continued)}

the "grumble line" (the point at which insufficient light would cause ordinary people to begin to grumble), (3) the 50-50 test (a room which is lighted $50 \%$ of the time is deemed acceptable), and (4) the "hypothetical observer" (onc who, when passing from onc room to the next, would notice or not notice the changed lighting).

Still needed, however, are clarification of the weight to bc given considerations involving local conditions and determination of the effect changing standards of sufficient amounts of 1 ight will ha:e on right-to-light litigation. 
Section 9.0

LABOR

Bezdek, Roger. "Marketing, Manpower, Consumer, and Environmental Issues," Chapter VII in Analysis of Policy Options for Accelerating Commercialization of Solar Heating and Cooling Systems. Washington, DC: The George Washington University, 1977. $467 \mathrm{p}$.

Available from: Local library; NTIS, Report No. TID-27597, PC \$14.50, MF $\$ 3.00$.

Marketing issues are discussed within the context of the Technology Delivery System. Manpower education and training aspects of solar energy technology are examined, and consumer affairs and environmental issues relating to solar heating and cooling are analyzed.

Burke, Kenneth J. "Energy and the Law: Problems and Challenges of the Late '70s," Study Materials, Copyright 1978, The American Law Institute.

SEe GENERAL SOLAR LAW

Environmetal Law Institute. Legal Barriers to Solar Heating and Cooling Buildings, Springfield, VA: National Technical Information Service; 1978.

SPP. SOLAR HEATING AND COOLING

Reitze, Arnold W., Jr.; Prezyna, Ann E. "Utilizing Solar Power - The Institutional Challenges." Environmental Comment. pp. 1-5; April, 1976.

SE CONSUMER PROTFCTIION

Thomas, William A. Proceedings of the Workshop on Solar Energy and the Law, Fehruary 10, 1975, Arlington, VA. An Interim Report Submitted to the National Science Foundation. Chicago, IL: American Bar Foundation; March, 1975. 28 p.

SEe GENERAL SOLAR LAW 
Section 10.0

LAND USE

AIA Research Corporation. Ear1y Use of Solar Energy in Buildings: A Study of Barriers and Incentives to the Widespread Use of Solar Heating and Cooling Systems. Washington, DC: August, 1976.

See BUILDING CODES

Becker, Ralph E., Jr. "Common Law Sun Rights: An Obstacle to Solar Heating and Cooling?" Journal of Contemporary Law. Vol. 3 pp. 19-36; Winter, 1976.

Available from : Local library.

It is unlikely that the following traditional common law doctrines will prove useful to solar energy development: (1) the Doctrine of Ancicnt Lights of England, rejected in the United States, which does not allow a landowner to block his neighbor's light; (2) implied easements for light and air, which have been upheld only in cases where property abutted a public street; and (3) the private nuisance action for obstruction of light and air, which has been upheld only in cases of spite fences where malice is the sole motive.

Uther common law device may become techniques for protecting solar rights; (1) cujus est solum ejus est usque ad coelum et ad infernos ("he who owns the soil owns also to the sky and to the depths") which recognizes usable airspace as a severable conveyable propcrty right; (2) express easements for solar energy which would be useful in established neighborhoods; (3) restrictive convenants which would allow land developere to include acoess tu solar energy in their declaration of convenants, conditions, and restrictions; (4) private nuisance actions where the utility of the defendant's conduct (e.g., cultivating a shade tree) is balanced against the gravity of the plaintiff's harm (e.g., loss of investment in solar heating units).

Beyond the common law, state and local legislation can provide protection through zoning ordinances or prior appropriation systems for solar energy. 


\section{LAND USE (Continued)}

Bersohn, David L. "Securing Solar Energy Rights: Easements, Nuisance or Zoning." Columbia Journal of Environmental Law. Vo1. 3 pp. 112-152; 1977.

Available from: Local 1ibrary.

Traditional legal doctrines available for securing solar access rights include easements, nuisance, and zoning. Easements for solar energy may be held to be easements in gross rather than the more valuable easements appurtenant, and the cost of obtaining a solar easement could be prohibitive. Solar easements could be analogized to public utility easements if solar energy was considered necessary to the public welfare. Solar energy claims must be distinguished from common law nuisance claims of obstruction of light and air because the common law claims have met consistent judicial rejection. An effective statutory nuisance could be created by state legislatures.

Zoning for insolation would overcome the obstacles inherent in other theories of rights to sunlight. New York City attempts to establish simple controls to achieve desirable standards for light by ordinance but does not mandate access to direct sunlight. Oregon requires that zoning and land use regulations consider solar energy development and utilization. Zoning appears to be the most effertive approach to establishing solar rights.

Bezdek, Roger. "Legal and Regulatory Issues." Chapter IV in Analysis of Policy Options for Accelerating Commercialization of Solar Heating and Cooling Systems. Washington, DC: The George Washington University; 1977. 467 p.

Available from: Local library; NTIS, Report No. TID-27597, PC \$14.50, MF $\$ 3.00$.

This chapter provides a comprehensive discussion of four legal approaches of limited usefulness for protecting property owners' sunrights: (1) doctrine 


\section{LAND USE (Continued)}

of ancient lights, (2) analogies to radio and television transmissions, (3) nuisance law, and (4) prescriptive easements. Equal consideration is given to the following widely used devices: (1) express easements, (2) restrictive convenants, and (3) land use planning. The transferable developmental rights concept is discussed as an innovative but complex approach of untested value.

Governments can promote solar access by updating old laws and developing new ones. Criteria for evaluating proposed laws are outlined, and twelve cooperative federal-state actions are listed.

Seven other problem areas are examined: (1) antitrust objectives in the solar market might be frustrated unless the government uses procurement policies and aids small businesses; (2) property tax assessors may discriminate against solar homeowners because of the added value concept, and bills attempting to remedy this situation contain serious legal deficiencies; (3) solar home financing is made difficult by federal regulatory and secondary market constraints, as well as conservative lender policies; (4) labor law issues arise through union resistance to new technologies, jurisdictional d1sputes, and conflicts over work assignments; (5) high costs of solar mobile homes presents a major market obstacle; (6) mandatory solar installation requirements might constitute a "taking" under the Constitution which entails compensatory payments; and (7) significant uncertainty exists over the appropriate regulatory policies and the impact of public utility law in service and rate administration, regulatory jurisdiction, and utility participation in the solar market.

Booz-Allen and Hamilton, Inc. The Effectiveness of Solar Energy Incentives at the State and Local Level. Washington, DC: U.S. Federal Energy Administration; March, 1976 .

See FINANCING/INSURANCE

D'Aurio v. Board of Zoning Appeals, 401 N.Y.S. 2d 425 (1978). 
LAND USE (Continued)

Available from: Local law library.

Plaintiffs sought a zoning variance to permit installation of a solar heating unit on their front lawn. Defendant Board of Zoning Appeals denied the variance application because there were no unusual circumstances peculiar to plaintiffs' property. Plaintiffs sought to reverse the Board's determination. HELD: Plaintiffs failed to demonstrate practical difficulties or significant economic injury warranting a zoning variance, and defendant's denial of the variance was not arbitrary and unreasonable. For defendant.

Eisenstadt, Melvin M•; Long, Stephen C. M•; Utton, Albert E. "A Proposed Solar Zoning Ordinance," The New Mexico Energy Institute, University of New Mexico, Albuquerque, New Mexico, Report No. NMEI 76-103. November, 1977.

Available from: Solar Energy Information Center, Solar Energy Research Institute, 1536 Cole Boulevard, Golden, CO 80401.

Zoning is the most desirable and legally appropriate tool for creating a solar right. If a solar zoning ordinance is to be effective, it must result in maximum protection for solar users with minimum inconvenience to neighbors.

The paper includes a Model Municipal Solar Zoning Ordinance, with extensive comments on the purpose and rationale for each section. The proposed ordinance does not grant an absolute right to sunlight, but rather attempts to balance the competing interests in the context of public policy to meet reasonableness requirements.

Eisenstadt, Melvin M.; Utton, Albert E. "Solar Rights and Their Effect on Solar Heating and Cooling," Proceedings of the Consumer Conference on Solar Energy Development: Consumer Conference on Solar Energy Development; October 2-5, 1976; Albuquerque, NM; Albuquerque, NM: New Mexico Solar Energy Association; 1976. Pp. 302-309. 


\section{LAND USE (Continued)}

Available from: Local library; New Mexico Solar Energy Association, P. 0. Box 2004, Santa Fe, NM 87501, $\$ 10.64$ (inc1. postage).

Legal analysis shows that the creation of solar rights is within the zoning power of municipalities. Access to solar energy can be obtained by mearis of easements and mutual convenants; however, zoning provides the most practical method, particularly in established neighborhoods.

Solar rights are property rights and may be bought, suld, lcased, and generally treated in the same manner as other incidents of real property ownership. They are subject to both zoning and eminent domain. Creation of this new property right may be problematic, since creating a solar right for individuals places a burden upon their neighborc. In order lu blake the concept more acceptable to the public, complicated tradeoffs must be made. Adjudicating these tradeoffs will require a person knowledgeable in solar energy matters to administer the solar zoning ordinances.

If extensive solar energy use for heating and cooling is to hernme a reality, one problem that must be solved is that nf nne party chading a neigh bor's collector. Without adequate legal protection for the collector, solar energy use wuld come to a standstill. Zoning ordinanccs which treat the problem before a lawsuit arises would be instrumental in encouraging solar use and would also eliminate the relay of solar dcvclopment.

Eisenstadt, Melvin M.; Utton, Albert E. "Solar Rights and Their Effect on Solar Heating and Cooling." Natural Resources Inmrnal. Vol. 16 (No. 2) pp. 363-410; April, 1976.

Available from: Local library.

What are the solar property rights of a landowner? Certain implied easements for light and air have been upheld as a form of property with value which may be sold or conveyed. Express easements may be created by grant, 


\section{LAND USE (Continued)}

reservation, or convenant. In new development tracts, easements created by convenant are more efficient than mutual grant arrangements for light and air. Property rights to airspace may be treated between landowners to create reciprocal solar rights. If easements are defined in terms of solar energy instead of visible light, the property right protected by the easement is considerably broadened and strengthened.

Solar rights may be created by zoning as long as the regulations do not violate the 5 th and 14 th Amendments to the Constitution. Balancing social gains effected by solar systems against social losses will support the validity of zoning principles. Additional legal difficulties with solar rights include reasonableness requirements, unsuitability of downtown areas, pre-existing structures, and compensation for zoning variances.

To facilitate acceptance of solar rights, certain tradeoffs must be made, such as giving up part of a solar right to gain public approval. A solar administrator or master familiar with the values associated with such tradeoffs would be one means of settling disputes.

"Express Easement of Light, Air, and View." 142 AlR 467 (1943).

SEe SOLAR ACCESS RICHTS

Fontainebleau Hotel Corp. v. Forty-Five Twenty-Five, Inc., 114 So. 2d 357 (F1a. 1959)

SEe SOLAR ACCESS RIGHTS

Gevurtz, Franklin. "Obstruction of Sunlight as a Private Nuisance." California Law Review. Vo1. 65: pp. 94-119; January, 1977.

Available from: Local library.

In adjudicating rights between landowners, courts in both England and America have not proterted direct access to sunlight because land develop- 


\section{$\underline{\text { LAND USE (Continued) }}$}

ment has been deemed more important. Easements to light and air have traditionally been defeated on the same theory. Although a right to light might not prevent development, it might require courts to award compensatory damages to injured landowners.

Where express easements or zoning schemes prove inadequate, nuisance law could protect the solar user. In a nuisance cause of action for solar rights, a plaintiff seeking damages would have to prove intent to harm, substantiality of harm, and unreasonableness of the obstruction. Plaintiffs seeking an injunction must show that their harm outweights the utility of the detendant's action, the damages suffered, and the relative ability of the parties to avoid the harm.

Great Britain. Laws, Statutes, etc. Rights of Light Act. 7 \& 8 Eliz. 2, C. $56, \mathrm{~s}^{3}$.

SEe INTERNATIONAL IAAW

Harris, Willlam R. Is the Right to Light a California Necessity? Santa Monica, CA: Rand Corporation. December, 1975.

See STATE LEGISLATION AND PROGRAMS

Hillhouse, Karin H.; Kohler, E. E.; Ltroff, R. A.; Miller, A. S. Legal and Insticutional Yerspectives on Solar Energy in Colorado: A Case Study of Land Use and Energy Decision-Making. (Final Report) Environmental Law Institute; Washington, DC; November, 1977.

See STATE LEGISLATION AND PROGRAMS

Jones, Nancy Lee. "Solar Rights: The Present Status of Legal Access to Light and Possible Constitutional objections to Federal Legislation." U.S. Library of Congress, Congressional Research Service; Washington, DC: June, 1977. 


\section{LAND USE (Continued)}

See FEDERAL LEGISLATION AND PROGRAMS

Kraemer, Sandy F. Solar Law: Present and Future, with Proposed Forms.

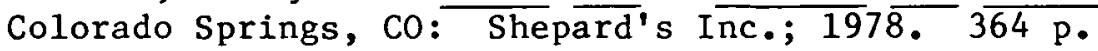

See SOLAR ACCESS RIGHTS

Kraemer, Sandy F.; Felt, James G. "Solar Shade Control." Energy Communications. Vol. 3 (No. 3) pp. 213-220; 1977.

Available from: Local library.

Laws enacted to promote solar development should reach certain goals:

protecting solar users from shadow, (2) complementing private easements and covenants, and ( 3 ) avoiding unnecessary litigation. Historically, the United States does not recognize a right to light; however, definition of solar rights will encourage solar development.

The simplest, most direct approach would be to declare shading a solar collector a public nuisance. Given the current broad definition of public nuisance, such a declaration would be considered constitutional as serving the public intcrest within the boundaries of the state police power.

The text of a model solar shade control law is given. The law would affect only trees and shrubs and would resolve about two-thirds of solar shading problems.

Maioriello v. Arlotta, $364 \mathrm{~Pa} 557,73$ A2d 374 (1950).

SE SOLAR ACCESS RIGHTS

Miller, Alan S. "Solar Energy and Land Use in Colorado." Environmental Law Repuiter. Vol. 6 pp. 50039=50046; July, 1976 . 


\section{LAND USE (Continued)}

Available from: Local library.

Solar energy development will depend on the resolution of legal issues. including the establishment of a legal right to sunshine. Nuisance law, easements, zoning schemes, and variance procedures may be used to establish a solar right. As an alternative to zoning, condemnation procedures may be used if solar energy is deemed a public benefit. Conversely, zoning regulations may restrict solar development with height restrictions, sideyard and setback provisions, use classifications, and aesthetic controls.

Public utility commissions will play a major role in solar development. Utility rate structures will determine the amount of money a solar user can save on utility bills. In Colorado, the PUC recently authorized a demand energy rate structure which discriminates against solar users. However, regulations may encourage solar use by increasing minimum insulation standards, requiring utility participation in solar energy projects, and liberally interpreting the entry requirements to the energy market. Utility commissions' authority to regulate the end-use of energy and to interpret monopoly franchise restrictions may be used to encourage or discourage solar development.

The report concludes with a review of proposed federal legislation to provide incentives for the development of solar heating and cooling.

Miller, Alan S. "Solar Energy and Public Lands." Journal of Contemporary Law. Vo1. 4 (No. 1): pp. 78-93; Winter, 1977. Available from: Local library.

What are the possibilities for locating solar power energy plants on public lands?

Physical needs of the solar power plant include a sunny climate, water for steam-driven turbines, level terrain, stable soil conditions, and vegetation 


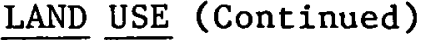

to prevent erosion. Because of the difficulty of storing large amounts of energy, solar plants will be most efficient where the time of energy production coincides with peak demand. Access to transmission lines must be considered in siting solar plants. Any use of public lands will require approval of an environmental impact analysis.

Procedural barriers to the use of public lands for solar power plants include requirements for comprehensive land use plans and restrictions regarding sales, withdrawals, and rights-of-way. State and local land use controls may also pose administrative barriers to solar plant construction.

Moskowitz, Daniel P. "Legal Access to Light: The Solar Imperative." Natural Resources Lawyer. Vol. 9 (No. 2) pp. 177-208; 1976.

Seé SOLAR ACCESS RIGHTS

Myers, Barry Lee. "Solar Access Rights in Residential Developments." The Practical Lawyer. Vo1. 24 (No. 2) pp. 13-20; March 1, 1978.

See SOLAR ACCESS RIGHTS

Note. "Taxation of Easement in Airspace." Maryland Law Review. Vo1. 3 (No. 2) pp, 159-190; 1973.

Available from: Local library.

In Macht v. Department of Assessments (266 Md.602, 296 A.2d 162, 1972) the court held that "we see no reason why land, improvements and airspace could not be separately valued for assessment purposes, so long as the sum of the elements did not exceed the value of the whole."

Morton Macht leased a block of airspace above the Macht Building to the Charles Street Development Corporation to provide light and air to the 


\section{LAND USE (Continued)}

Corporation's Blaustein Building. The court affirmed an assessment and taxation of airspace separately from all other interests in fee in a case where the entire fee interest, including the airspace, is held by one owner.

Phelps, Dennis L.; Yoxal1, Richard R. "Solar Energy: An Analysis of the Implementation of Solar Zoning." Washburn Law Journa1. Vo1. 17 (No. 1) pp. $146-162 ; 1977$.

Available from: Local 11brary.

Conventional zoning, specifically tallored to the needs of solar energy, is the most feasible and effective legal method of ensuring rights to uninterrupted direct access to sunlight.

Successful solar zoning schemes must be carefully drawn to fit within a constitutional framework. Zoning must not be so restrictive as to constitute a "taking" requiring compensation, and it must impact equally on all affected groups to satisfy requirements of equal protection.

Zoning generally enjoys a presumption of constitutionality, and it is most easily accepted in newer, less-developed communities, where most solar energy residences are being constructed. However, creation of new zoning ordinances requires investments of municipal time and funds, and solar zoning may be difficult to adapt to existing neighborhoods.

Plıillips, J. D. Aoocasment of a single Tramily Residence Sular Healiug System in a Suburban Development Setting. Project Phoenix. Colorado Springs, $\mathrm{C} 0$ : Colorado Springs Department of Public Utilities; July, 1976.

SEe LOCAL LEGISLATION AND PROGRAMS 
LAND USE (Continued)

Reitze, Arnold W., Jr.; Reitze, Glenn L. "Protecting a Place in the Sun." Environment Vol. 18 (No. 5) pp. 2-4; June, 1976 and Vol. 18 (No. 6) p. 44; July/August, 1976.

Available from: Local library.

This is a summary of Glenn Reitze's article "A Solar Rights Zoning Guarantee: Seeking New Law in Old Concepts."

Reitze, Glenn L. "A Solar Rights Zoning Guarantee: Seeking New Law in 01d Concepts." Washington University Law Quarterly. Vol. 1976 (No. 3) pp. 376-402; Summer, 1976.

Available from: Loca1 library.

Solar energy may be analogized to water or oil and gas as a natural resource subject to property law and administrative regulation. Traditional real property law, including affirmative and negative easements (both express and implied), the British doctrine of ancient lights (rejected in the United States); and common law nuisance and trespass law may be extended to cover solar energy disputes. Building codes and zoning regulations guaranteeing solar access may be based on the government's police power or its promotion of the general welfare.

A statewide program guaranteeing solar access could be developed using the 11-point proposal given in the last section of the article.

Uniled States v. Causby, 328 U.S. 256 (1946).

Available. from: Local law library.

Plaintiffs owned a farm over which military aircraft flew when landing and taking off. Plaintiffs claimed that the noise and nuisance caused by low 


\section{LAND USE (Continued)}

altitude overflights disrupted their poultry business and, in so doing, constituted a "taking" of their property in violation of the Fifth Amendment to the Constitution. The Court of Claims held that the Government had taken an easement over plaintiffs' property in the value of $\$ 2,000$. HELD: The common law doctrine that ownership of property extends indefinitely above and below the land has no place in the modern world. However, aircraft flying out of prescribed Civil Aeronautics Authority navigable airspare can be so direct and immediate an intcrference with the enjoyment of land as to constitute a taking of the land. Reversed and remanded.

U.S. Energy Research and Development Administration. Division of Solar Energy. Solar Access and Land Use: State of the Law, 1977. Rockville, MD: National Solar Heating and Cooling Information Center; 1977.

Avallable from: Solar Energy Information Center, Solar Energy Rescarch Institute, 1536 Cole Boulevard, Golden, C0 80401.

No right of access to sunlight exists in America, hut. 1egal experts agree that some sort of access should be guaranteed. Public and private nuisance suits and implicd and prcacriptive edsentuls lave been of $11 \mathrm{~m} 1 \mathrm{red}$ usefulness. Uther approaches, such as transferable development rights, are uncescod.

Express easements to sunlight (i.e., rights that have been mutually agreed upon between landowners) are renngnized hy state law and may be cnforccd in the courts. Express easement purchase, however, may be expensive and the enforcement procedure long and costly. Restrictive covenants are viable only in new, singly developed plans.

Most promising are state and local laws enacted to promote energy-conserving land use plans which are backed by the "pursestring persuasion" of the federal government. The potentially most effective laws are: require new developments to include provisions for sun rights, confirm the rights of private property owners to negotiate easements for light and air, restrict 


\section{LAND USE (Continued)}

new vegetation that would block light to solar collectors, add solar energy impact consideration before issuance of a building permit, and urge legislative declarations that solar energy serves a public purpose, thereby benefitting the solar user in litigation against a less beneficial user.

Williams, John Eddie, Jr. "The Dawning of Solar Law." Baylor Law Review. Vo1. 29 (No. 4) pp. 1013-31; Fal1, 1.977.

Available from: Local library.

A system for granting solar rights may be modeled on any of several existing legal devices, each with advantages and disadvantages.

The doctrine of ancient lights has been consistently rejected by courts in this country. Easements would be flexible and effective, but they are expensive and their acquisition cannot be assured. Restrictive covenants are of little value in established neighborhoods. Zoning is vulnerable to political changes and constitutional challenge. Transferable development rights have achieved only limited acceptance. Protection of solar rights through the law of nuisance would require frequent litigation. Analogies to allocation systems for other natural resources are not particularly useful.

Legislation specifically designed to encourage solar uses should be passed. Various property, sales, and income tax mechanisms will promote solar energy development. Building codes must be modified to promote solar equipment utilization. Financial institutions must be stimulated to lend generously for solar uses. Public utilities must be assured a compatible role in the fulure energy sccnario. Potential labor disputes and antitrust problems might be overcome by anticipatory legislation.

Zillman, Donald N.; Deeny, Raymond. "Legal Aspects of Solar Energy Development." Arizona State University Law Journal. Vol. 1976 (No. 1): pp. $25-58 ; 1976$. 


\section{LAND USE (Continued)}

Available from: Local law school library.

Existing property law will have an impact on solar encrgy development. Expless, Implied, prescriptive, necessary, or statutory easements might be obtained by the homeowner to guarantee light. Restrictive covenants may prevent homeowners from installing solar equipment. However, a developer might use restrictive covenants to encourage solar use. The law of nuisance is likely to apply to solar energy development.

The market will play a significant role in solar energy development. Anticompetitive practices may emerge, and government may intrude upon the free market system.

Land use planning doctrine will also affect the marketability of solar devices. The carefully drafted solar zoning ordinance might stimulate solar development, and building codes may be enacted which impact residential use of solar energy.

Leylslation has been enacted which affects solar commercialization. State statutes provide tax incentives for installing oolar energy devlees and create state agencies with responsihility over colar encrgy mattexs aud laud use. A series of model ordinances addressing solar easements and land use planning matters has been prepared by the American Bar Foundation. 
Section 11.0

LOCAL LEGISLATION AND PROGRAMS

Booz-Allen and Hamilton, Inc. The Effectiveness of Solar Energy Incentives at the State and Local Level. Washington, DC: U.S. Federal Energy Administration; March, 1976.

See FINANCING/INSURANCE

Kraemer, Sandy F. Solar Law: Present and Future, with Proposed Forms. Colorado Springs, Co: Shepard's Inc.; 1978. 364 p.

See SOLAR ACCESS RIGHTS

Lior, Noam; Lepore, John A.; Shore, Sidney. "Residential Solar Heating Retrofit in the Urban Environment," in Vol. 4 of Sharing the Sun! Solar Technology in the Seventies (pp. 36-52). Proceedings of the Joint Conference of the American Section, International Solar Energy Society and Solar Energy Society of Canada, Inc., August 15-20, 1976, Winnipeg. 10 vols. Cape Canaveral, FL: American Section of the International Solar Energy Society; 1976.

See ENVIRONMENTAL ASPECTS

Phillips, J. D. Assessment of a Single Family Residence Solar Heating System in a Suburban Development Setting. Project Phoenix, Colorado Springs, $\mathrm{co}:$ Colorado Springs Department of Public Utilities; July, 1976.

Available from: Local 1ihrary; NTIS, Report No. PB $263192, \$ 9.00$.

The Project Phoenix solar heated home is a demonstration project designed to provide an alternative to conventional heating systems for residential application. Chapter 10 identifies potential legal causes of action by solar systems owners, including public or private nuisance sults, private condemnation, and transferable development rights. The legal research committee drafted two solar zoning ordinances. Existing building codes covered most solar installations; however, a new chapter was proposed for 


\section{LOCAL LEGISLATION AND PROGRAMS (continued)}

the Uniform Mechanical Code of Colorado Springs. The proposed zoning ordinances and building code chapter are included in the appendices of the report.

Schifflett, Mary; Zuckerman, John V. "Solar Heating and Cooling: State and Municipal Legal Impediments and Incentives." Natural Resources Journal Vol. 24 pp. 313-336; April, 1978.

See GENERAL SOLAR LAW

U.S. Energy Research and Development Administration. Division of Solar Energy. Solar Access and Land Use: State of the Law, 1977. Rockville, MD: National Solar Heating and Cooling Information Center, $\overline{1977}$.

See LAND USE

White, Sharon. Santa Clara, California, Community Center: Commercial Solar Demonstration, Legal A1ternatives, Implications, and Financing of Solar Heating and Cooling by a Municipal Corporation. (Final Report) Washington, DC: U.S. Energy Research and Development Administration; 1976.

Available from: Local library; NTIS, Report No. SAN/1083-76-1, PC \$7.25, MF $\$ 3.00$.

Many legal issues confront a municipal corporation planning to promote solar energy utilization within its jurisdiction. Privately owned public utilities may challenge the municipal action as ( 1 ) an impairment of contract, (2) a "taking" without compensation, (3) unfair competition, (4) an antitrust violation, and (5) an improper expenditure of public funds; however, none of these challenges is likely to be successful.

Actions of municipal corporations are circumscribed by the "public purpose" doctrine: funds cannot be spent for other than some benefit to the commu- 


\section{LOCAL LEGISLATION AND PROGRAMS (continued)}

nity. The broad interpretations recently given the term "public purpose" suggest that municipal efforts toward solar utilization are within the doctrine.

Municipalities can employ various techniques to hasten solar energy utilization. Compulsory private solar use would be unconstitutional, but municipalities can legally "encourage" solar utilization through tax incentives, utility rate structure modifications, zoning, various land use planning techniques, easements, building codes, conversion of municipal facilities to solar heating and cooling, and financing of solar utilization efforts. 
THIS FAGE INTEINTIONALLY IHFI RLANK. 
Section 12.0

OCEAN ENERGY

Hallberg, C. R., "International Regulatory Authority Concerning Ocean Thermal Energy Conversion Devices." in Ocean Thermal Energy Conversion: Legal, Political, and Institutional Aspects. Edited by H. Gary Knight, J. D. Nyhart, and Robert E. Stein. Lexington, MA: Lexington Books; 1977. 243 p.

Available from: Local library; Lexington Books, 125 Spring St., Lexington, MA $02173, \$ 16.00$.

A number of international agencies regulate maritime activities. Although OTEC devices have not been considered by any of these agencies, the Intergovernmental Maritime Consultative Organization appears to offer the best mechanism for establishing adequate standards and regulations to govern OTEC systems.

Higgins, James C. "Ocean Thermal Energy Conversion Plants: Federal and State Regulatory Aspects," in Ocean Thermal Energy Conversion: Legal, Political, and Institutional Aspects. Edited by $\mathrm{H}$. Gary Knight, J. D. Nyhart, and Robert E. Stein. Lexington, MA: Lexington Books; 1977. 234 p.

Available from: Local library; Lexington Books, 125 Spring Street, Lexington, MA 02173, $\$ 16.00$.

Federal regulatory structures now exist for the regulation of Ocean Thermal Energy Conversion plants in commercial development; but because other interests might be involved (as in cable laid under state territorial waters), the States should be given a role in siting, operation, and product distribution.

No power currently exists providing authorization and licensing for operation of OTEC facilities beyond U.S. territorial waters. Once established, OTEC facilities are covered by a large body of statutes administered by the U.S. Coast. Guard, the Army Corps of Engineers, and several agencies, includ- 


\section{OCEAN ENERGY (Continued)}

ing the Environmental Protection Agency, which monitors pollution, and the Department of Interior.

Congress should specify that the licensing powers shnuld he assumad by onc of these agencies, and the licensing decision should incorporate the desires of the coastal states and their regulatory laws concerning coastal areas.

Hollick, Ann L. "International Political Implications of Ocean Thermal Energy Conversion Syatems," in Ocuan Thermal Energy Cunverslun: Legal, Political, and Institutional Aspects. Edited by H. Gary Knight, J. D. Nyhart, and Robert E. Stein. Lexington, MA: Lexington Books; 1977. p. 243.

Available from: Local library; Lexington books, 125 Spring St., Lexington, MA $02173, \$ 16.00$.

Legal jurisdiction over OTEC plants will be based on the Informal Single Negotiating Test (ISNT) of the 1975 United Nations Law of the Sea Conference. Although the ISNT is not a formal treaty, it provides a basis for defining jurisdictional boundaries.

The international system includes national, subnational, and supernational entities aligned in East-West and North-South political divisions. These complex relationships will affect the scientific, economic, and military functions of OTEC plants. National jurisdiction extends to OTEC plants within 200 miles of the rnast; beyond that, various interlidiond agencics, such as the Intergovernmental Maritime Consultative Organization, the International Energy Agency, SEATO, and NATO, will claim regulatory control.

Knight, H. Gary. "International Jurisdictional Issues Involving OTEC Installations," in 0cean Thermal Energy Conversion: Legal, Polltical, and Institutional Aspects. Edited by $\mathrm{H}$. Gary Knight, J. D. Nyhart, and Robert E. Stein. Lexington, MA: Lexington Books; 1977. 243 p.

Available from: Local library; Lexington Books, 125 Spring St., Lexington, MA $02173, \$ 16.00$. 


\section{OCEAN ENERGY (Continued)}

The siting of OTEC devices presents international legal problems concerning jurisdiction. Applicable law is determined by the location of the surface and water column in internal waters, territorial sea, special continuous zones, or high seas. The OTEC anchor in the seabed will be governed by its location under a territorial sea, on the continental shelf, or deep ocean floor. Currently developing law considers economic resource zones, the "common heritage" notion for deep seabed minerals, the possible regulation of scientific research throughout the world ocean, and the archipelagic concept.

Mayo, Louis. H. Legal-Institutional Arrangements Facilitating offshore Wind Energy Conversion Systems (WECS) Utilization. Washington, DC: George Washington University; September, 1.977 ; DOE/NSF $/ 19137-77 / 3.93$ p.

SEe WIND RESOURCES

Naef, Frederick E. "Economic Aspects of Ocean Thermal Energy Conversion," in vol. 5 of Sharing the Sun! Solar Technology in the Seventies (p. 392411). Proceedings of the Joint Conference of the American Section, International Solar Energy Society and Solar Energy Society of Canada, Inc., August 15-20, 1976, Winnipeg. 10 vols. Cape Canaveral, FL: American Section of the International Solar Energy Suciety, 1976.

Available from: Local library; ISES members: Publishing Office, 205B McDowell Hall, University of Delaware, Newark, DE 19711, $\$ 50.00$ (Eet); Nonmembers: Pergamon Press, Maxwell House, Fairview Park, Elmsford, NY $10523, \$ 250.00$ (set).

Ocean Thermal Energy Conversion (OTEC) can be implemented now with existing technology, but various engineering refinements and legislative actions are needed to improve economic competitiveness and reduce investment risk.

Several unique characterist1cs assure OTEC a significant role in the energy future. OTEC units can be mass-built at existing shipyards and then towed to their sites. Plants can be relocated to satisfy shifting markets. OTEC 


\section{OCEAN ENERGY (Continued)}

units would operate 24 hours a day with zero fuel costs and would have only minimal environmental impact. Products from OTEC could include not only direct electrical power but also ammonia (for fertilizer) and liquid hydrogen.

Several legal, policy, technical, and financial constraints impede largescale OTEC implementation. An OTEC plant's legal status as either a moored ship or an artificial island is uncertain. Location of plants beyond the 200-mile territorial limit may spawn international difiputrri. Mrplnyment of a large number of OTEC units could lead lo a clalm system for desirable sites. Failure of the government to declare OTEC development a national priority and the lack of a viable demonstration program have left investment uncertainty unmitigated.

Two governmental actions would stimulate OTEC development by making investment more predictable. First, OTEC plants should be designated as factory ships to reduce legal uncertainties by bringing tethered plants within the existing body of maritime law. Second, the government should designate a lead agency to coordinate postdemonstration implementation of OTEC.

Nyhart, J. D. "Problems of Legal Responsibility and Liability to be Anticipated in OTEC Operations," in Ocean Thermal Energy Conversion: Legal, Political, and Institutional Aspects. Edited by H. Gary Knight, J. D. Nyhart, and Robert E. Stein. Lexington, MA: Lexington Books; 1977. 243 p.

Available from: Local library; Lexington Books, 125 Spring Street, Lexington, MA $02173, \$ 16.00$.

The development of Ocean Thermal Energy Conversion (OTEC) structures, which may become a significant source of offshore energy, raises several complex legal issues and demands some policy decisions.

The principal source of anticipated problems is in deciding what choice of forum (i.e., court) would inherit litigation involving OTEC operations. 


\section{OCEAN ENERGY (Continued)}

Certainly federal regulatory law has a role, but U.S. civil and criminal law will be applicable where there is a federal question or diversity of litigants. Common tort and contract law is also applied by states to their coastal.possessions. Maritime law would be applicable in circumstances where the OTEC structure was defined as a vessel.

Areas of financing and ownership patterns must be better defined so as to determine liability in personal injury and death claims. Other liabilities might arise with navigational operations, in design and construction of OTEC structures, and in environmental law.

Probably no existing body of law adequately covers potential problems in the OTEC area. Congress should note trouble spots or inconsistencies in the present laws (i.e., the Outer Continental Shelf Lands Act and the Deep Water Port Act of 1974) and improve on the present law in anticipation of the new offshore technology.

Riggs, John H. "Legal Aspects of Financing Ocean Thermal Energy Plants," in Ocean Thermal Energy Conversion: Legal, Political, and Institutional Aspects. Edited by H. Gary Knight, J. D. Nyhart, and Robert E. Stein. Lexington, MA: Lexington Books; 197\%. 243 p.

Available from: Local library; Lexington Books, 125 Spring Street, Lexington, MA 02173, $\$ 16.00$.

Ocean Thermal Energy Conversion (OTEC) devices will be massive in size and technology, requiring equally massive amounts of financing. It is probable that financing methods will be similar to those presently used to underwrite oil drilling and production platforms and supertankers.

Three principal types of financing are available: (1) use of unsecured debentures or preferred or common stock; (2) ship mortgage financing with the possibility of federally assisted ship mortgage bond financing under Title XI of the Merchant Marine Act (1936); and (3) lease financing, which 


\section{OCEAN ENERGY (Continued)}

operates in such a fashion that owners will trade their tax benefits (accelerated depreciation and investment tax credit) on the OTEC equipment to a bank in return for a low financing charge.

New legislation would be required to implement ship mortgaging and lease financing for OTEC devices. In this area it is critically important that Congress or the Executive Branch clarify the availability of preferred financing for OTEC devices; for despite the ecological and operational advantages of U'l'LC operations, under presently available financing methods OTEC devices will be at a disadvantage in competition for capital funds.

U.S. Energy Research and Development Administration. A National Plan for Encrgy Research, Development, and Demonstration: Creating Energy Choices for the Future. June, 1977.

See BIOMASS

U.S. Federal Energy Administration. Project Independence Blueprint: Final Task Force Report, Solar Energy. Washington, DC: Government Printing Office; 1974 .

See FEDERAL LEGISLATION AND PROGRAMS

Washom, Byron. "Spatial and Emerging Use Conflicts nf Orean Space," in Ocean Thermal Energy Conversion: Legal, Political and Institutional Aspects. Edited by H. Gary Knight, J. D. Nyhart, and Robert E. Stein. Lexington, MA: Lexington Books; 1977. 243 p.

Available from: Local library; Lexington Books, 125 Spring St., Lexington, MA $02173, \$ 16.00$.

Ocean Thermal Energy Conversion (OTEC) power generation plante present potential conflicts with navigation, fishing, offshore mining and explora- 


\section{OCEAN ENERGY (Continued)}

tion, liquified natural gas (LNG) conversion plants, municipal waste disposal, and military operations. Resolution of conflicts will depend on location of the OTEC device and the definition of oceanic jurisdictional boundaries. Existing legislation, international agreements, and customary international law do not address the OTEC concept. Domestic and international regulatory agencies might be two means of resolving conflicts relevant to OTEC systems. 
THIS PAGE INTENTIONALLY LEFT BLANK 
Section 13.0

PATENTS AND LICENSES

Bezdek, Roger. "Energy Research and Development Administration (ERDA) Patent Policy," Chapter $V$ in Analysis of Policy options for Accelerating Commercialization of Solar Heating and Cooling Systems. Washington, DC: The George Washington University; 1977. 467 p.

Available from: Local library; NTIS, Report No. TID-27597, PC \$14.50, MF $\$ 3.00$.

ERDA has no separate patent policy for its Solar Heating and Cooling SHAC program. Development of a separate policy is not recommended because (1) the patent principles are generic to the entire federal agency research and development efforts, and (2) ERDA's statutory authority was adequate. However, regulations and statutes that dictate patent policy require the following modifications: (1) inventors-contractors should receive title to patents, or at least exclusive rights to develop them; (2) the contractor should receive irrevocable licenses; (3) federal government patent policy regulations should be more specific to avoid administrative confusion; (4) the contractor or other licensee should receive exclusive licenses as protection from infringement; and (5) the contractor's background patent policy should be expanded to permit assignment or exclusive licensing of patents.

Burke, Kenneth J. "Energy and the Law: Problems and Challenges of the Late '70s," Study Materials, Copyright 1978, The American Law Institute.

SEe GENERAL SOLAR LAW

Ezra, Arthur A. "Technology Utilization: Incentives and Solar Energy." Science. Vol. 187 (No. 4178) pp. 707-713; February 18, 1975.

See FEDERAL LEGISLATION AND PROGRAMS 


\section{PATENTS AND LICENSES (Continued)}

Kraemer, Sandy F. Solar Law: Present and Future, with Proposed Forms. Colorado Springs, Co: Shepard's Inc.; 1978. 364 p.

See SOLAR ACCESS RIGHTS

Sperber, Phillip. "Government Contracting: Perpetuating the Energy Crisis." American Bar Association Journal. Vo1. 62 pp. 1301-1304; October, 1976.

Available from: Local library.

Current policy requiring grants of nonexclusive licenses to government contractors hinders energy research and development. Advocates of socialized research argue that nonexclusive licensing precludes monopoly status in those companies that perform government contract research for profit. Such licensing arrangments ensure competition in the development of energy-saving innovations trom prototypes to the market-ready stage.

Conversion of prototypes into market-ready products requires investment of private industry personnel and resources beyond proportions justified by the slim profit on contract research. Small research companies would be most reluctant to risk substantial investments without assurance of exclusive licensing. Thus, the corporate giants would dominate a socialized research market.

Exclusive licensing is the strongest inducement to make the benefits of energy research widely available in the shortest time. The government should grant exclusive rights for a limited period during which the contractor must expend diligent effort toward commercialization of its innovation. At the end of a fixed period a review would result in (1) termination of the exclusive rights, (2) renewal of the exclusive period, or (3) grant of irrevocable exclusive rights, depending on the contractor's performance and success during the initial exclusive period. 
Section 14.0

PHOTOVOLTAICS

Bradley, Jerry 0.; Costello, Dennis R. "Techno-Economic Aspects of a Photovoltaic Electric Power System Interfaced with Electric Power Utilities," in vol. 6 of Sharing the Sun! Solar Technology in the Seventies (pp. 159-161). Proceedings of the Joint Conference of the American Section, International Solar Energy Society and Solar Energy Society of Canada, Inc., August 15-20, 1976, Winnipeg. 10 vols. Cape Canaveral, FL: American Section of the International Solar Energy Society; 1976.

Available from: Local library; ISES members: Publishing office, 205B McDowe11 Ha11, University of Delaware, Newark, DE 19711, $\$ 50.00$ (set); nonmembers: Pergamon Press, Maxwe11 House, Fairview Park, Elmsford, NY 10523 , $\$ 250.00$ (set).

Photovoltaic Electric Power Systems (PEPS) must be accepted and integrated into the electric utility industry if they are to provide a significant portion of future energy needs.

The maximum justifiable investment by a utility in PEPS is equal to or less than the value of the cost savings that would result from displaced fuel costs and displaced generating capacity costs. However, the government can act to increase this value and the corresponding level of investment to reflect the external social benefits of PEPS by adopting policies such as tax incentives and low-interest loans for PF.PS develnpment.

U.S. Energy Research and Development Administration. A National Plan for Energy Research, Development, and Demonstration: Creating Energy Choices for the Future. June, 1977:-

See BIOMASS

U.S. Federal Energy Administration. Project Independence Blueprint: Final Task Force Report, Solar Energy. Washington, DC: Government Printing Office; 1974 . 
TIIIS FAGE INTENTIONALL' ' LEFT BLANK 
Section 15.0

SOLAR ACCESS RIGHTS

Becker, Ralph E., Jr. "Common Law Sun Rights: An Obstacle to Solar Heating and Cooling?" Journal of Contemporary Law. Vol. 3 (No. 1) pp. 19-36; Winter, 1976.

Seę LAND USE

Bersohn, David L. "Securing Solar Energy Rights: Easements, Nuisance or Zoning." Columbia Journal of Environmental Law. Vol. 3 (No. 1) pp. 112$152 ; 1977$.

See LAND USE

Bezdek, Roger. "Legal and Regulatory Issues." Chapter IV in Analysis of Policy Options for Accelerating Commercialization of Solar Heating and Cooling Systems. Washington, DC: The George Washington University; 1977. 467 p.

See LAND USE

Bliamptis, E. E. "Rights to Sunshine." Applied Optics. V.ol. 8 pp. 1890-2; August, 1976.

Available from: Local library.

A formula is proposed whereby the shadow cast by a building at noon on the day of the summer solstice determines where a building could be located on a plot of land. It would offer assurance to neighboring landowners that their access to sunlight would not be impaired by any new buildings on adjacent land. 
SOLAR ACCESS RIGHTS (Continued)

Bury v. Pope, 1 Cro. Eliz. 118, 78 Eng. Rep. 375 (Exc. 1586).

SEe INIE RINATIUINAL LAW

Charles Semon and Co. Ltd. v. Bradford Corp., 2 Ch. 737 (1922).

SEe INTERNATIONAL LAW

Cohen v. Perrino, 355 Pa. 455, 50 A.2d 348.

Available from: Local law library.

An action in equity for the removal of a wall. Defendant built a wall, for spite, which completely blocked the flow of light and air to plaintiffs' windows. plaintitis contended the blocking of light and air impaired their health, lowered the value of their property, and created a nuisance. HELD: A landowner may build a structure on the landowner's land which obstructs the light, air, and view of an adjoining owner, regardless of the purpose or the malicious intent behind the construction of the structure. For defendant.

Colls v. Home and Colonial Stores Ltd., H. L.(E)179 (1904).

SEe INTERNATIONAL LAW

D'Aurio v. Board of Zoning Appeals, 401 N.Y.S. 2d 425 (1978).

See LAND USE

Eisenstadt, Melvin M•; Utton, Albert E. "Solar Rights and Their Effect on Solar Heating and Cooling." Natural Resources Journal. Vol. 16 (No. 2) pp. 363-410; Apri1, 1976. 


\section{SOLAR ACCESS RIGHTS (Continued)}

See LAND USE

"Express Easement of Light, Air, and View." 142 AlR 467 (1943).

Available from: Local law library.

Annotated case law on the creation, construction, and effect of deeds and contracts containing provisions concerning light, air, and view.

Fontainebleau Hotel Corp. v.Forty-Five Twenty-Five, Inc., 114 So. 2d 357 (Fla. 1959).

Available from: Loca1 law library.

An action in equity to enjoin defendant. Fontainebleau Hotel from further construction on a 14-story addition to its hotel. Plaintiff, an adjoining landowner, maintained that the addition would shadow the swimming pool and sunbathing area of the plaintiff's hotel, that construction would render plaintiff's beach unsuitable for guest use, and that defendant's acts were intentionally malicious. On the basis that there is no right to use one's property to injure another, the lower court granted a temporary injunction. HELD: Only the lawful rights of another are protected from acts of an adjoining landowner. American law recognizes no legal property right to the access of light from adjoining lands. Therefore, a structure which obstructs the light to another's land is not subject to an action by the injured party, regardless of whether it was erected for spite. Temporary injunction reversed.

Goble, Dale D. "Solar Rights: Guaranteeing a Place in the Sun." Oregon Law Review. Vol. 57 (No. 1) p. 94134; 1977.

Available from: Local library. 


\section{SOLAR ACCESS RIGHTS (Continued)}

The fundamental legal impediment to widespread adoption of residential solar energy systems is the lack of guaranteed access to direct sunlight. This impediment could be eliminated by creation of a solar right which provides (1) a definition compatible with solar energy system requirements, (2) an equitable method of solar rights assignment, and (3) a method of enforcement of solar rights.

Current property policy, which favors land development, hinders the creation of a solar right. Legislative responses to solar needs have produced tax incentives and zoning modifications conducive to solar energy but have not created the necessary vested property interest to ensure the solar right.

Suggested models for solar rights legislation are as follows: (1) prescriptive rights to sunlight as an incident to land ownership, (2) prescriptive rights to light, (3) a vesting of the right in the first person filing notice of intent to install a solar collector, and (4) a prior appropriation system analogous to the water law of western states.

Great Britain. Laws, Statutes, etc. Rights of Light Act. $7 \& 8$ E1iz. 2, C56, \$3.

SEe TNTE.RNATIONAL LAW

Harris, William R. Is the Right to Light a California Necessity? Santa Monica, CA: Rand Corporation. December, $197 \overline{5}$.

See STATE LEGISLATION AND PROGRAMS

Jones, Nancy Lee. "Solar Rights: The Present Status of Legal Access to Light and Possible Constitutional objections to Federal Legislation." U.S. Library of Congress, Congressional Research Service. Washington, DC: June, 1977.

See FEDERAL LEGISLATION AND PROGRAMS 


\section{SOLAR ACCESS RIGHTS (Continued)}

Kraemer, Sandy F. Solar Law: Present and Future, with Proposed Forms. Colorado Springs, Co: Shepard's Inc., 1978. $364 \mathrm{p}$.

Available from: Local 1ibrary; Shepard/McGraw Hill Book Company, 400 North Cascade, Colorado Springs, CO 80903, $\$ 35.00$.

Solar systems require a direct source of sunlight for operation, but U.S. law provides little precedent for a "right to light." New legal concepts must be explored to guarantee an access to light and to assure expansion of solar energy use. The author reviews existing law concerning solar easements, covenants, solar zoning and planning, public and private nuisance law, eminent domain, appropriation doctrine, transferable development rights, air pollution, and building codes.

Model proposals and model state legislation concerning easements, planning, and shade control are set forth. Forms for private easement and covenant agreements are included.

Appendices introdure a solar glossary, summarize legal impediment 1ssues in solar use, and examine the role of public utilities, tax incentives, financing solar systems, mobile homes, tort liability, insurance and warranties, and mandatory installation. Also provided is a social acceptance survey with resulting data and a residential market estimate. An annotated bibliography of books and periodicals is included.

Kraemer, Sandy F.; Felt, James G. "Solar Shade Control." Energy CommunicaLiuns. Vol. 3 (No. 3) pp. 213-220; 1977.

See LAND USE

Maioriello v. Arlotta, 364 Pa. 557, 73 A.2d 374 (1950). 


\section{SOLAR ACCESS RICHTS (Continued)}

Available from: Local law library.

Defendant erected a ten foot wall on her own property which obstructed the light, air, and view of plaintiff, an adjoining owner. Plaintiff brought an action in equity to compel removal of the wall. HELD: (1) an owner has the privilege of building, on his own land, a structure which obstructs the light, air, and view of an adjoining owner, and (2) no implied easement exists for light and air in the absence of a shnwing nf ahanlyte necossity.

Miller, Alan S. "Solar Energy and Land Use in Colorado." Environmental Law Reporter. Vol. 6 p.p. 50039-50046; July, 1976.

See LAND USE

Moskowitz, Daniel P. "Legal Access to Light: The Solar Imperative." Natural Resources Lawyer. Vol. 9 (No. 2) pp. 177-208; 1976.

Available from: Local library.

The law of real property, as it presently exists, provides insufficient legal protection for access to sunlight necessary for heating and cooling buildings with solar energy.

The English doctrine of "ancient lights," through which a prescriptive easement to receive light may he arquired after 20 years, has been rejected in every American jurisdiction. However, the imperative to develop solar. energy may yield a judicial reappraisal of "ancient lights," and some American jurisdictions have accepted an implied easement of light theory.

Express grants of easements to sunlight are generally upheld by American courts. To enforce express easements, courts must resolve two issues: (1) what degree of interference is actionable, and (2) under what circumstances the easement is abandoned. 


\section{SOLAR ACCESS RIGHTS (Continued)}

Mere nuisance actions for the obstruction of sunlight are ineffective, since there is no right to receive light.

Zoning, through techniques such as setback requirements and height restrictions, is a logical, effective, and probably constitutional method of ensuring access to direct sunlight.

Myers, Barry Lee. "Solar Access Rights in Residential Developments." The Practical Lawyer. Vo1. 24 (No. 2) pp. 13-20; March 1, 1978.

Available from: Local 1ibrary.

Solar access rights must be carefully created, taking into account both the technical consideration of the legal devices used and the unique natural considerations affecting solar energy use.

To determine whether a legally protected interest in sunlight is created through easements, covenants, equitable servitudes, or zoning, the lawyer must consider the precision of the language of the grant, the term of the right, statutory requirements, and consistency with preexisting covenants.

The many natural considerations which affect a solar right include ( 1 ) topography, (2) seasonal variations, (3) angle of the sun, (4) direction of the collectors, (5) size of the building, and (6) the height of the collectors.

Since solar rights can severely restrict other rights and land uses, they must be drawn as narrowly as possible.

Nadler, Arnold D. "Planning Aspects of Direct Solar Energy Generation." AIP Journa1. pp. 339-351; October, 1977. 
SOLAR ACCESS RIGHTS (Continued)

Available from: Local library.

Several public policies will play important roles in promoting tho application of solar energy. Furemost among these policies is creation of an efficient and equitable system for protecting property interests in incident sunlight.

Other important public policies to promote solar energy inrlürei (1) property and other tax incentives, (2) life-cycle costing, (3) building code and subdivision regulation reform, and (4) electric utility rate structure modifications.

Parker and Edgarton v. Foote, 19 Wend. 309 (N.Y. Sup. Ct. 1838).

Available from: Local law 1ibrary.

An action by plaintiff houseowner against an adjoining houseowner whose newly constructed house blocked the light to plaintiff's windows. Plaintiff had enjoyed unobstructed sunlight for 24 years prior to the erection of defendant's house. HELD: Twenty years of uninterrupted enjoyment of unobstructed light does not give a landowner a legal right against a neighbor obstructing the light to his windows, nor may an owncr presume a grant of this right from his prior uninterrupted use. For defendants.

Reitze, Arnold W., Jr.; Reitze, Glenn L. "Protecting a Place in the Sun." Environment. Vol. 10 (No. 5) pp. 2-4; June, 1976 and Vol. 18 (No. 6) p. 44; July/August, 1976.

See LAND USE

Reitze, Glenn L. "A Solar Rights Zoning Guarantee: Seeking New Law in 01d Concepts." Washington University Law Quarterly. Vol. 1976 (No. 3) pp. 376-402; Summer, 1976. 
SOLAR ACCESS RIGHTS (Continued)

See LAND USE

U.S. Energy Research and Development Administration. Division of Solar Energy. Solar Access and Land Use: State of the Law, 1977. Rockville, MD: National Solar Heating and Cooling Information Center, 1977.

See LAND USE

White, Mary D. "The Allocation of Sunlight: Solar Rights and the Prior Appropriation Doctrine." University of Colorado Law Review. Vo1. 47 pp. 421-447; Spring, 1976.

Available from: Local library.

Creation of a legal right to sunlight raises two important issues: (1) who will allocate the rights, and (2) on what legal principles will the allication be based?

An analysis of two pertinent constitutional doctrines (the power to regulate interstate commerre and the dortrine of federal preemption) indicates that Congress is the most appropriate body to resolve the allocation issue. In the absence of federal legislation, however, other governmental bodies will assume the role of allocator.

New fields of law usually develop by analogy to existing areas of law. The allocation of sunlight presents problems similar to the allocation of other natural resources, particularly water. The doctrine of prior appropriation provides the most suitable model for adaptation to solar rights. A system of allocation of sunlight patterned on the appropriation of water doctrine would provide efficient processes for the use and protection of one's sunlight, and for the transferability of solar access rights. 


\section{SOLAR ACCESS RIGHTS (Continued)}

Wilkinson, H. W. "Let There Be More Light." The New Law Journal. Vol. 18 pp. 7-8; January. 4, 1978.

SEe INTERNATIONAL LAW

Williams, John Eddie, Jr. "The Dawning of Solar Law." Baylor Law Review. Vol. 29 (No. 4) pp. 1013-31; Fall, 1977.

8LU LAND U\&E 
Section 16.0

SOLAR HEATING AND COOLING

Arthur D. Little, Inc. Residential Solar Heating and Cooling Constraints and Incentives. A Review of the Literature. Washington, DC: U.S. Departmen - of Housing and Urban Development; May, 1976.

Available from: Local 1ibrary; NTIS, Report No. PB 258238 , PC $\$ 9.50$, MF $\$ 3.00$.

This report provides a review and assessment of the literature on market constraints on solar heating and cooling, and possible governmental-incentives to overcome them. Five categories of constraints are analyzed: (1) economic/financial, (2) technical, (3) social/political, (4) institutional/ industrial, and (5) regulatory/legal. Incentives are examined in terms of their potential usefulness in overcoming constraints in three categories: (1) economic/financial, (2) promotional, and (3) regulatory/legal. A cost-benefit analysis is used to evaluate alternative economic incentives.

The report contains matrices which show constraints and impacted groups, constraints and incentives in research studies, recently enacted state incentives, and proposed state and federal incentive legislation. Abstracts are provided of completed studies and studies in progress dealing with constraint.s and incentives.

Bezdek, Roger. "Building Codes, Standards, and Warranties." Chapter VI in Analysis of Policy Options for Accelerating Commercialization of Solar Heating and Cooling (SHAC) Systems." Washington, DC: The George washington University; 1977. $467 \mathrm{p}$.

See BUILDTNG CODES 


\section{SOTAR HEATING AND COOLING (Continued)}

Dikkers, Robert D. "Development and Implementation of Standards for Solar Heating and Cooling Applications," in vol. 1 of Sharing the Sun! Solar Technology in the Seventies (Pp. 83-90). Procecdings of the Joint Conference of the American Section, International Solar Energy Society and Solar Energy Society of Canada, Inc., August 15-20, 1976, Winnipeg. 10 vols. Cape Canaveral, FL: American Section of the International Solar Energy Society, 1976.

Available from: Local library; T.SFS memhers: Publishing officc, 205B McDowe11 Hal1, University of Delaware, Newark, DE 19711, \$50.00 (set); Nonmembers: Pergamon Press, Maxwell House, Fairvipw Park, Elmsford, NY $10523,3250.00(\mathrm{sel})$.

Solar programs at the National Bureau of Standards (NBS) focus on the development and implementation of standards and performance criteria for solar heating and cooling. The NBS has prepared interim performancc criteria and procedures for testing the thermal performance of solar collectors and storage devices in support of the programs of other governmental agenclés (HUD and EREA)

Currenlly, the NBS' is working on the following: (1) intcrim performance criteria for commercial solar energy systems, (2) intermediate standards, (3) draft standards for materials, (4) a solar collector testing laboratory accreditation program, and (5) identification and development of other needed standards.

Eisenstadt, Melvin M.; Utton, Albert E. "Solar Rights and Their Effect on Solar Heating and Cooling," Proceedings of the Consumer Conference on Solar Energy Development: October 2-5, $1976 ; \Lambda 1$ buquerque, NM; Consume Conference on Solar Energy Development; Albuquerque, NM: New Mexico Solar Energy Association; 1976. pp. 302-309.

See LAND USE 
SOLAR HEATING AND COOLING (Continued)

Environmental Law Institute. Legal Barriers to Solar Heating and Cooling of Buildings. Springfield, VA: National Technical Information Service; 1978.

Available from: Local library; NTIS, Report No. HCP/M2528-01, PC $\$ 9.50$, MF $\$ 3.00$.

The substance of this publication can be found in chapters IV-VI of "Analysis of Policy Options for Accelerating Commercialization of Solar Heating and Cooling Systems."

Feldman, S. L.; Anderson, B. Utility Pricing and Solar Energy Design. Worchester, MA: Clark University; September 30, 1976.

Available from: Local library; NTIS, Report No. PB 263798 , PC $\$ 9.00$, MF $\$ 3.00$.

This report attempts to develop a methodology to assess the impact of solar heating and cooling on electric utilities. The first section states the research methods in a general manner. The second section reports the results and implications of the methodology as applied in various regional settings.

The authors address both the impact of solar energy on the electric utility industry and, conversely, the impact of utility rate structure on the adoption of solar energy systems.

General Electric Company. Space Division. General Electric Company Survey to Define Impact of Statewide Building Codes on Solar HVAC Systems: Commercial Buildings. National Technical Information Service, 1976. 
SOLAR HEATING AND COOLING (Continued)

Available from: Local library; NTIS, Report No. C00/2683-76/11, PC $\$ 8.00$, MF $\$ 3.00$.

This document reports the results of a statewide survey to identify the potential impact of building codes and solar energy laws on the solar heating and cooling of buildings (SHACOB).

Since no two states are alike with respect to building codes or solar energy laws policy, it is difficult to predict the exact effect that existing codes have on SHACOB. The report recommends that ERDA encourage the various national model code associations to establish special solar energy regulations separate from existing building codes so as to reduce uncertainty about solar installations.

The report includes cxtensive tables on the codes of each state and items in each of the standard codes affecting SHACOB.

Johnson, Augustue C. "Commercialiration of Solar Hualing and Coollng of Bulldings," in vol. 10 of Sharing the Sun! Solar Technology in the SevenLles (pp. 35-39). proceedings of the Joint Conference of the American Section, International Solar Energy Society and Solar Energy Society of Canada, Inc., August 15-20, 1976, Winnipeg. 1, vols. Cape Canaveral, FL: American Section of the International Solar Energy Society; 1976.

Available from: Local library; ISES members: Publishing Office, 205B McDowell Hal1, University of Delaware, Newark, DE 19711, $\$ 50.00$ (set); Nonmembers: Pergamon Press, Maxwell House, Fairview Park, Elmsford, NY $10523, \$ 250.00$ (set).

Present national programs for energy conservation and solar heating and cooling in buildings could be aided by a federally integrated program that would (1) remove barriers to the introduction of energy-saving technologies into new and existing buildings and (2) improve state programs for regulating, encouraging, and enforcing the use of such technology. 
Lorsch, Harold G. "Effect of Solar Home Heating on Electric Utilities," in vol. 9 of Sharing the Sun! Solar Technology in the Seventies (pp. 97-112). Proceedings of the Joint Conference of the American Section, International Solar Energy Society and Solar Energy Society of Canada, Inc., August 15-20, 1976, Winnipeg. 10 vols. Cape Canavera1, FL: American Section of the International Solar Energy Society; 1976.

Available from: Local library; ISES members: Publishing office, 205B McDowe11 Hal1, University of Delaware, Newark, DE 19711, $\$ 50.00$ (set); Nonmembers: Pergamon Press, Maxwell House, Fairview Park, Elmsford, NY 10523 , $\$ 250.00$ (set).

This paper compares what effects the following have on electric utilities: (1) conventional electric resistance heating, (2) direct solar heating, and (3) solar-assisted heating.

Although peak demands for solar and conventional homes are identical, the annual load factor for solar homes is $40 \%$ to $50 \%$ lower. Therefore, under rate structures that recover costs through an energy charge alone, electric utilities will experience a revenue deficiency from those customers with solar heating unless solar customers are charged at a different rate. However, if solar users are charged at rates which recover the actual costs to serve, their anticipated monetary savings from solar conversion will be negated.

U.S. Congress. House. Committee on Banking, Currency, and Housing. Low-Interest Loans for Residential Solar Heating and Cooling Equipment. Hearings before the Subcommittee on Housing and Community Development on H.R. 3849, H.R. 8524, 94 th Congress, 1st Session, 1975.

See FINANCING/INSURANCE 
SOLAR HEATING AND COOLING (Continued)

U.S. Department of Housing and Urban Development (HUD), National Bureau of Standards, and U.S. Department of Commerce. Interim Performance Criteria for Solar Heating and Combined Heating/Cooling Systems and Dwellings. Washington, DC: Government Printing Office, 1975.

Available from: Local library; GPO, Stock No. 003-003-01389-9, \$1.90.

Under the provisions of the 1974 Solar Heating and Cooling (SLIAC) Demonstration Act, this document was developed to provide interim performance criteria for the design and evaluation of SHAC systems to be demonstrated by HUD in residential construction. The document is divided into two parts: (1) Systems and Components (Chapter 1 through 6) deals with interim performance criteria for heating, cooling, and domestic hot water systems and their subassemblies; and (2) Dwellings and Sites (Chapters 7 through 13) presents performance criteria dealing with the interactions between, the solar energy system and its surrounding environment, the dwelling and the site. Both parts are organized on the basis of the first tax performance attributes listed as follows: (1) functional, (2) mechanica1, (3) structural, (4) safety, (5) durab1liț/reliability, and (6) maintainahility. An additional acrribuce, visual characteristics, is considered under Dwe11ings and Sites.

U.S. Energy Research and Development Administration. A National Plan for Energy Research, Development, and Demonstration: Creating Energy Choices for the liuture. June, 1977.

See BIOMASS

U.S. Federal Energy Administration. Project Independence Blueprint: Final Task Force Report, Solar Energy. Washington, DC: Government Printing Office, 1974 .

See FEDERAL LEGISLATION AND PROGRAMS 
SOLAR HEATING AND COOLING (Continued)

U.S. Federal Energy Administration. Energy Rate Initiatives: Study of the Interface Between Solar and Wind Energy Systems and Electric Utilities. McLean, VA: MITRE Corporation; 1977 .

See UTILITIES

U.S. Federal Energy Administration. Solar Heating and Cooling of Buildings (SHACOB) Commercialization Report. Final Report (Part A: Options and

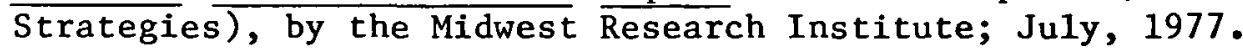

Available from: Local library; NTIS, Report No. HCP/M70065-01/1 (Vo1. 1), PC $\$ 4.50, \mathrm{MF} \$ 3.00 ; \mathrm{HCP} / \mathrm{M70065-01/2}$ (Vo1. 2), PC $\$ 9.00, \mathrm{MF} \$ 3.00 ; \mathrm{HCP} / \mathrm{M} 70065$ $-01 / 3\left(V_{01} .3\right), \mathrm{PC} \$ 8.00, \mathrm{MF} \$ 3.00$.

A small cömmercial market for solar heating and cooling of buildings (SHACOB) currently exists in the United States, but this energy source may. not reach its full potential without incentives. This report recommends government-sponsored economic incentives, including reduction of economic barriers by the creation of codes and standards, reduction of legal and institutional barriers, and a SHACOB incentive strategy coordinating the interface between solar systems and electric utilities.

Thrce volumes: Vol. 1 (Fxesutive Summary), Vol. 2 (Technical Report), Vol. 3 (Appendices). 
THIS PAGE INTENTIONALLY LEFT BLANK 
Section 17.0

SOLAR THERMAL POWER SYSTEMS

Burke, Kenneth J. "Alternative Forms of Energy." Lecture, Environmental Law for the Colorado Practitioner. Reprinted by Continuing Legal Education in Colorado, Inc., Denver, 1975.

See GENERAL SOLAR LAW

Lorsch, Harold G. "Effect of Solar Home Heating on Electric Utilities," in vol. 9 of Sharing the Sun! Solar Technology in the Seventies (pp. 97-112). Proceedings of the Joint Conference of the American Section, International Solar Energy Society and Solar Energy Society of Canada, Inc., August 15-20, - 1976, Winnipeg. 10 vols. Cape Canaveral, FL: American Section of the International Solar Energy Society, 1976.

See SOLAR HEATING AND COOLING

U.S. Energy Research and Development Administration. A National Plan for Energy Research, Development, and Demonstration: Creating Energy Choices for the Future. June, 1977.

See BIOMASS

U.S. Federal Energy Administration. Project Independence Blueprint: Final Task Force Report, Solar Energy. Washington, DC: Government Printing Office; 1974 .

See FEDERAL LEGISLATION AND PROGRAMS 
THTS PAGE INTENTIONALLY LEFT BLANIK. 
Section 18.0

STANDARDS

Arthur D. Little, Inc. Residentia1 Solar Heating and Cooling Constraints and Incentives. A Review of the Literature. Washington, DC: U.S. Department of Housing and Urban Development; May, 1976.

See SOLAR HEATING AND COOLING

Eisenhard, Robert. State Solar Energy Legislation of 1976: A Review of Statutes Relating to Buildings. Washington, DC: U.S. Energy Research and Development Administration, Division of Solar Energy, and U.S. Department of Housing and Urban Development, Office of Policy Development and Research; September, 1977.

See STATE LEGISLATION AND PROCRAMS

Hirshberg, Alan; Schoen, Richard. "Barriers to the Widespread Utilization of Residential Solar Energy: The Prospects for Solar Energy in the U.S. Housing Industry." Policy Sciences. Vol. 5 (No. 4): pp. 453-468; December, 1974.

See BUILDING CODES

Moore, Elizabeth C. "For Potential Customers for Solar Equipment: No News is Bad News." Solar Age. Vo1. 2 pp. 10-16; December, 1976.

Avai1able from: Local library.

The U.S. government has been slow to provide information regarding standards for solar energy equipment. Consequently, architects or builders interested. in designing or building solar houses must either wait until approved standards have been developed or proceed with the preliminary standards established by HUD. 


\section{STANDARDS (Continued)}

In the private sector, the American National Standards Institute (ANSI) is directing a major national voluntary standard effort in solar energy and cooling. The American Society of Heating, Refrigerating, and Air Conditioning Engineers (ASHRAE) has assigned committees to develop standards on thermal properties of collectors and storage facilities. If these standards are subsequently accepted by ASHRAE and ANSI, many states might adopt them.

Scott, Ronald D. "The United States National Program for the Demonstration of Solar lleating and Cooling in Buildings: Progress Report," in vol. 1 of Sharing the Sun! Solar Technology in the Seventies (pp. 126-141). Proceedings of the Joint Conference of the American Section, International Solar Energy Society and Solar Energy Society of Canada, Inc., August 15-20, 1976, Winnipeg. 10 vols. Cape Canaveral, FL: American Section of the International Solar Energy Society; 1976.

See BUILDING CODES

U.S. Federal Trade Commission. Bureau of Competition. The Solar Market: Proceedings of the Symposium on Competition in the Solar Energy Industry. Washington, $\overline{\mathrm{DC}}$ : Government Printing Ufifice; June, $19 \overline{78 .}$

Available from: Local library; GPO, Stock No. U18-UUU-UU216-1, \$b.2b.

A transcript of papers presented and panelists' remarks and comments at the December 1977 FTC Bureau of Competition symposium, a four-part examination of the competitive aspects of the developing solar energy industry.

Part I examines solar energy standards and the standards development process and includes tables of equipment types with their developmental priority rating, the organization responsible for the development of the standard, and a timetable for development. The related antitrust issues in setting and enforcing standards are given detailed analysis. Federal government and 


\section{STANDARDS (Continued)}

major oil company involvement in the solar industry is examined in Part II. Part III covers barriers and incentives to the commercialization of solar energy, and Part IV consists of descriptions by government representatives of the solar programs of their agencies.

AIA Research Corporation. Early Use of Solar Energy in Buildings: A Study of Barriers and Incentives to the Widespread Use of Solar Heating and Cooling Systems. Washington, DC: August, 1976.

See ANTITRUST

Waksman, D. Plan for the Development and Implementation of Standards for Solar Heating and Cooling Applications. Washington, DC: U.S. Department of Commerce; August, 1976.

Available from: Local library; NTIS, Report No. PB 257-769, PC $\$ 5.25$, MF $\$ 3.00$.

This report provides an overview of existing solar equipment standards and standards societies. Recommendations are made for development and implementation of standards for solar equipment and building materials in the areas of health and safety, testing, and minimum levels of technical performance. Standards are divided into three groups--methods of test standard, recommended practice standards, and specification standards--arranged in tables according to the type of equipment or material, its developmental priority and status, the schedule for development, and the organization, responsible for development. 
THIS PAGE INTENTIONALLY LEFT BLANK 
Section 19.0

STATE LEGISLATION AND PROGRAMS

Bezdek, Roger. "Regional Aspects of the Incentive Program," Chapter VIII in Analysis of Policy Options for Accelerating Commercialization of Solar Heating and Cooling systems. Washington, DC: The George Washington University; 1977. 467 p.

See FEDERAL LEGISLATION AND PROGRAMS

Binns, W. Patrick. "State Legislative Initiatives for Solar Energy Implementation." Industrialization Forum 7, (No. 2-3) 1976. pp. 3-9.

Available from: Local lịbrary.

States can employ various institutional tools to reduce the energy impact of buildings. One such tool is to enact codes that require conformance to energy efficiency levels prior to the granting of construction permits. Measures which encourage retrofitting of existing buildings with energy-conserving equipment can also be used. Utility rates can be revised to require charges that reflect the real cost of producing power. Mandatory life-cycle costing methods would extend budgetary concern beyond the traditional lowest first cost criterion.

States can lower the overall energy demand by fostering solar heating and cooling of buildings ( $S H A C O B$ ). SHACOB would be promoted by tax incentives for residential conversion; retrofitting of state-owned buildings; enforceable solar access rights; solar research, development, and demonstration programs; solar information and education projects, and encouragement of local and regional participation in solar energy planning.

California Energy Resources. Conservation and Development Commission. "Solar Energy in California: Residential Thermal Applications." Unpublished draft report. Sacramento, CA: February, 1978. 
Available from: California Energy Resources, Conservation and Development Commission, 111 Howe Avenue, Sacramento, CA 95825, \$4.68 (incl. postage).

This report contains sections dealing with the state of the solar industry, consumer issues, utility roles, impacts of widespread solar use, solar economics, and legal and building code issues related to solar use. Each section includes recommendations for California actions which may be appropriate for other states.

The appendices contain lists of solar manufacturers, distributors, architects, engineers, builders and developers, contractors, environmental and c1cizen action groups, lobbyists, unions, and financial institutions that are likely to have roles in statewide solar energy development. other appendices summarize existing solar codes and statewide solar legislation.

A28

Eisenhard, Robert M. Building Energy Authority and Regulations: State Activity. National Bureau of Standards. NBSIR 76-986. Springfield, VA: National Techniçal Information Service, January, 1976.

Available from: Local library; NTIS, Report No. PB $250858, \$ 4.50$.

State legislation relating to solar energy, retrofitting, insulation, and other building energy matters is listed by state. Enacted legislation and bills pending in the 1975 legislative session are included.

A28.89

Eisenhard, Robert. State Solar Energy Legislation of 1976: A Review of Statutes Relating to Buildings. Washington, DC: U. S. Energy Research and Development Administration, Division of Solar Energy, and U.S. Department of Housing and Urban Development, Office of Policy Development and Research; September, 1977.

Available from: Local library; NTIS, Report No. PB 273899. 


\section{STATE LEGISLATION AND PROGRAMS (Continued)}

Forty-four acts and resolutions relating to solar energy were enacted by state legislatures during 1976. Most of this state activity deals with the following: (1) tax incentives, (2) proposals for the location of the Solar Energy Research Institute, (3) creation of state energy offices, and (4) development of solar standards.

This report provides detailed information on the state legislation enacted in 1976, including bill number, date, abstract, citation, and name and address of the state agency and official responsible for administering the state act.

Appendix A is a collection of all forms developed by the states for their solar programs. Appendix B contains copies of all bills and resolutions enacted by the states in 1976 .

General Electric Company. Space Division. General Electric Company Survey to Define Impact of Statewide Building Codes on Solar HVAC Systems: Commercial Buildings. National Solar Demonstration Program. National Technical Information Service, 1976.

See SOLAR HEATING AND COOLING

Harris, William R. Is the Right to Light a California Necessity? Santa Monica, CA: Rand Corporation; December, 1975.

Available from: Local library; NTIS, Report No. AD-A026 660/1st, PC \$4.00, MF $\$ 2.25$.

The impediments to a legally protected interest in sunlight may be overcome by zoning for solar system districts, high-rise development districts, transferable solar energy rights, and other land use planning schemes. A property interest ensuring access to sunlight would protect and encourage investments in solar energy property. Arbitration or condemnation proce- 
STATE LEGISLATION AND PROGRAMS (Continued)

dures would similarly encourage development of solar properties and allow for high-rise building.

Solar access rights could be created by federal, state, or local legislation; judicial decisions; or private agreement. Models for solar rights are found in Japanese legislation, the English "right to light," race-notice recordation systems, and nuisance concepts of liability for interference with solar access.

Higgins, James C. "Ocean Thermal Energy Conversion Plants: Federal and State Regulatory Aspects," in ocean Thermal Energy Conversion: Legal, Political, and Institutional Aspects. Edited by $\mathrm{H}$. Gary Knight, J. D. Nyhart, and Robert E. Stein. Lexington, MA: Lexington Books; 1977.

SEe OCEAN ENERGY

Hillhouse, Karin H.; Kohler, E. E.; Liroff, R. A.; Miller, A. S. Legal and Institutional Perspectives on Solar Energy in Colorado: A Case study of Land Use and Energy Decision-Making. (Fina1 Report). Environmental Law Institute; Washington, DC: 1977 November.

Available from: Local library; N'l'S, Report No. PB 279994 , PC \$9.50, MF $\$ 3.00$.

Colorado is the subject of an intensive case study which evaluates aspects of the state's institutional and regulatory structure which might present impediments to an emerging energy technology.

The report first analyzes federal jurisdiction over solar matters through agencies involved with land use, building, and energy planning. The report concludes that a federal solar loan program modeled after financing arrangements of the Rural Electrification Administration (REA) would stimulate the private utility sector in solar construction projects. 


\section{STATE LEGISLATION AND PROGRAMS (Continued)}

The existing Colorado regulatory structure is resistant to solar energy technologies. This structure can be changed if the Public Utilities Commission (PUC) assumes responsibility for energy mapping on a statewide basis. Because the PUC-regulated monopoly structure obstructs new energy development, the legislature should consider regulated competition among utilities and the PUC should establish regulations to promote solar energy service.

Land development must be planned for solar use. The report proposes a Colorado Solar Land Use Planning Act which would provide for comprehensive authority at the local government level to plan and to regulate for solar use.

Johnson, Milan; Tiedemann, Thomas F. Solar Energy Commercialization at the State Level: The Florida Solar Energy Water Heater Program. Cape Canavera1, FL: F1orida Solar Energy Center; March, 1977; FSEC-76-3. $132 \mathrm{p}$.

Available from: Local library; NTIS, Report No. PB 270158 , PC $\$ 7.25$, MF $\$ 3.00$.

This report presents a detailed study of current problems associated with the introduction and commercialization of solar energy, particularly solar domestic water heating, focusing on those aspects which impact on state legislation. Proposed or enacted state solar energy leglslation is critiqued in terms of its effectiveness in removing economic, legal, and technical barriers.

Interim criteria for Florida's solar energy testing and standards program are discussed, including certification of test facilities, collector performance test procedures, minimum performance standards, installation guidelines, solar water heater certification programs, and state procurement specifications for solar water heaters. 


\section{STATE LEGISLATION AND PROGRAMS (Continued)}

The four appendices contain (1) instructions for constructing a model solar water heater, (2) climatological data, (3) a recommended protective covenant against inharmonious land use and (4) a review of the status of utility-conducted research on Ocean Thermal Energy Conversion.

A2

Jones, R. G.; Stranck, Helen M.; Pelster, Joette M. Analysis of State Solar Energy Policy Options. Washington, DC: U.S. Federal Energy Administration. National Conference of State Legislatures; June, 1976.

Available from: Local library; NTIS Report No. PB 254730 , PC \$5.25, MF $\$ 3.00$.

The one state policy which will most significantly affect the rate of market penetration of solar energy systems is the reform of electric utility rates to achieve a close relationship between unit price and unit cost. Time-ofday pricing or peak-load pricing would accomplish this goal.

States should install solar thermal systems in state-owned buildings, both to reduce fuel costs and to increase public awareness of solar feasibility. States should also participate in available federal programs designed to provide assistance in the commercialization of solar products.

Mills, Jon; Woodson, R. D, "Energy Policy: A Test for Federalism," Arizona Law Review. Vol. 18 (No. 2) pp. 405-451; 1976.

See FEDERAL LEGISLATION AND PROGRAMS

A2a

A Forum on Solar Access (Proceedings of a forum held by the New York State Legislative Commission on Energy Systems). Reprinted by the National Solar Heating and Cooling Information Center, July 18, 1977.

Available from: National Solar Heating and Cooling Information Center, P. 0. Box 1607, Rockville, MD 20850, (800) 523-2929; in Pennsyvania (800) 462-4983. 
STATE LEGISLATION AND PROGRAMS (Continued)

This is a transcript of a meeting between solar energy legal experts and New York State legislators to analyze various approaches to protecting access to sunlight prior to the drafting of a solar access bill.

Testimony given covers a gèneral overview of types of solar systems and the history of solar access legislation in such areas as restrictions on height, size, location, and vegetation, with criticisms of each. Also covered are zoning variances and the constitutional constraints on land use controls, with a particular emphasis on New York case law.

Nyhart, J. D. "Problems of Legal Responsibility and Liability to be Anticipated in OTEC 0perations," in Ocean Thermal Energy Conversion: Legal, Political, and Institutional Aspects. Edited by $\mathrm{H}$. Gary Knight, J. D. Nyhart, and Robert E. Stein. Lexington, MA: Lexington Books; 1977 . 243 p.

See OCEAN ENERGY

Robbins, Richard L. "Building Codes, Land Use Controls, and Other Regulations to Encourage Solar Energy Use." Proceedings of the Consumer Conference on Solar Energy Development. Consumer Conference on Solar Energy Development; 0ctober 2-5, 1976; Albuquerque, NM. Albuquerque, NM: New Mexico Solar Energy Association; 1976. pp. 283-300.

Available from: Local library; New Mexico Solar Energy Association, P. 0. Box 2004, Santa Fe, NM 87501, $\$ 10.64$ (inc1. postage).

State and local governments can encourage solar energy use by updating existing building codes, land use controls, and other regulations to eliminate harriers that are remnants of past regulatory objectives. Furthermore, governments can protect solar skyspace either by legislation or eminent domain.

A state agency, established specifically to promote solar energy planning and use, could perform several function: (1) plan for statewide use of 


\section{STATE LEGISLATION AND PROGRAMS (Continued)}

solar energy systems, (2) generate model laws and regulations, (3) administer government financing programs, (4) oversee community planning activities, and (5) maintain a solar energy central clearinghouse.

Robertson, Bob J. "The Utility Role in Solar Commercialization." Proceedings of the Consumer Conference on Solar Energy Development: Consumer Conference on Solar Energy Development; October 2-5, 1976; Albuquerque, NM; Albuquerque, NM: New Mexico Solar Energy Association; 1976. pp. 490-502.

Available from: Local library; New Mexico Solar Energy Association, P. 0. Box 2004, Santa Fe, NM 87501, \$10.64 (inc1. postage).

The utility industry holds "a variety of views regarding the solar/utility interface. Utility interest in the successful commercialization of solar technology is based on the following reasons: (1) growing pressure for energy conservation makes solar energy a viable alternative; (2) the utility industry will require assistance in manaing load growth; and (3) utilities face environmental challenges in gaining approval for ncw sites and transmission and distribution lines. Discussion focuses on California's activities.

Although solar commercialization is not presently progressing rapidly, the following outside influence will accelerate its market development: (1) the Residential Energy Conservation Bond, which provides for a \$15 million bond issue to finance both residential solar heating and cooling systems; (2) Senate Bill 218, which authorizes a solar tax credit; and (3) Assembly Bill \#4032, which provides an incentive to public utilities to invest in facilities that use renewable energy sources. Moreover, a joint order from regulatory commissions to the public utilities requesting information about present and proposed solar projects could act as a data base upon which California regulatory policy will be formed regarding the solar/utility interface. 


\section{STATE LEGISLATION AND PROGRAMS (Continued)}

U.S. National Solar Heating and Cooling Information Center. State Solar Legislation (as of January 1978). Rockville, MD: NSHCIC; 1978.

Available from: National Solar Heating and Cooling Information Center, P. 0 . Box 1607, Rockville, MD 20850, (800) 523-2929; in Pennsylvania (800) 462-4983.

This document lists the existing state solar-related legislation (as of January 1, 1978) in four areas: (1) financial incentives, such as tax deductions for installation of solar units; (2) solar access, including the creation of voluntary solar easements; (3) standards for solar systems, both in performance criteria and testing procedures; and (4) building code provisions, providing that new construction facilitates future installation of solar devices. Addresses of relevant state agencies are provided.

Zillman, Donald N.; Deeny, Raymond. "Legal Aspects of Solar Energy Development." Arizona State University Law Journal. Vol. 1976 (No. 1); pp. 25-58; 1976.

SeE LAND USE 
THIS PACE INTENTIONALLY LEFT BLANK

116 
Section 20.0

TAX LAW

Bezdek, Roger. "Economic and Financial Incentives," Chapter II in Analysis of Policy Options for Accelerating Commercialization of Solar Heating and Cooling Systems. Washington, DC: The George Washington University; 1977. 467 p.

See FINANCING/INSURANCE

Booz-Allen and Hamilton, Inc. The Effectiveness of Solar Energy Incentives at the State and Local Level. Washington, DC: U. S. Federal Energy Administration; March, $\overline{1976 .}$

See FINANCING/INSURANCE

Ezra, Arthur A. "Technology Utilization: Incentives and Solar Energy," Science. Vol. 187 (No. 4178) pp. 707-713; February 18, 1975.

See FEDERAL LEGISLATION AND PROGRAMS

Hirshberg, Alan S. "Public Policy for Solar Heating and Cooling." Bulletin of the Atomic Scientists. Vol. 32 (No. 8) pp. 37-45; October, 1976.

See FINANCING/INSURANCE

Hyatt, Sherry V. "Thermal Efficiency and Taxes: The Residential Energy Conservation Tax Credit." Harvard Journal of Leglslation. Vol. 14 pp. $281-326 ; 1977$.

See FINANCING/INSURANCE 


\section{TAX LAW (Continued)}

Kraemer, Sandy F. Solar Law: Present and Future, with Proposed Forms.

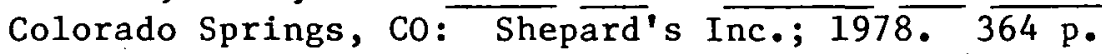

SEe SOLAR ACCF.SS RIGHTS

Moore, J. Glen. "Solar Energy Legislation in the 95th Congress: January through August 1977." U.S. Library of Congress, Congressional Research Service; Washington, DC: September 6, 1977. (Updated through November 1977.)

See FLDËRĀ LEGISLATION AND PROGRAMS

Note. "Taxation of Easement in Airspace." Maryland Law Review. Vol. 3 (No. 2) pp. 159-190; 1973.

See LAND USE

Petersen, H. Craig. The Impact of Tax Incentives and Auxiliary Fuel Prices on the Utilization Rate of Solar Energy Space Conditioning. Washington, DC: U. S. National Science Foundation; January, 1976.

Available from: Local library; NTIS, Report No. PB-252 538, PC \$6.50, MF $\$ 3.00$.

In this paper a market simulation inode1 (SEMS) is used to estimate the effects of alternative tax incentives on the market impact of solar energy for heating, cooling, and water heating. Five specific tax incentives are considered: (1) sales, (2) property tax exemptions for solar energy equipment, (3) rapid amortization of solar capital equipment, (4) tax deductions, and (5) tax credits. The possibilities of subsidized loans for solar energy equipment financing and utility surcharges and discounts for conventional energy used as solar auxiliary are also investigated. 
TAX LAW (Continued)

Roach, Fred; Noll, Scott; Ben-David; Shaul; Bickle, Larry; Schulze, William. Prospects for Solar Energy: The Impact of the National Energy Plan. (Informal Report) Los Alamos, NM: Los Alamos Scientific Laboratory; December, 1977.

Available from: Local library; NTIS, Report No. LA-7064-MS, PC \$4.50, MF $\$ 3.00$.

This report analyzes the potential for solar energy applications to residential space heating and hot water heating in single family residences with and without economic incentives. Prices of natural gas, heating oil, and electricity are projected for the period 1977 to 1985 and then compared with the costs of solar heating systems under three incentive plans: the National Energy-Plan (NEP) tax credit structure, a similar House of Representatives version, and a no-incentive situation. The projections for the solar systems are based on 20- and 30-year life-cycle costs and envision both continued regulation and deregulation of price controls on natural gas and oil production.

The competitiveness of solar systems will be greatly enchanced by incentives, although deregulation of conventional energy sources would produce substantially the same results without incentives. Domestic water heating systems would be highly competitive with electric resistance systems and competitive in some states with natural gas and oil over the 20-year projected period. Residential space heating systems would be economically feasible in many states over the 30-year period but competitive only with electric resistance systems.

U..S. Congress. House. Committee on Science and Technology. Solar Energy Legislation Through the 94 th Congress. U.S. Library of Congress. Congressional Research Service, Science Policy Research Division. Washington, DC: Government Printing Office; 1976.

See FEDERAL LEGISLATION AND PROGRAMS 
TAX LAW (Continued)

U.S. National Solar Heating and Cooling Information Center. State Solar Legislation (as of January 1978). Rockville, MD: NSHCIC; 1978.

See STATE LEGISLATION AND PROGRAMS

Zillman, Donald N.; Deeny, Raymond. "Legal Aspects of Solar Energy Development." Arizona State University Law Journal. Vol. 1976 (No. 1); pp. 25-58; 1976.

See LAND USE 
Section 21.0

TORT LIABILITY

Bezdek, Roger, "Building Codes, Standards, and Warranties." Chapter VI in Analysis of Policy Options for Accelerating Commercialization of Solar Heating and Cooling systems. Washington, DC: The George Washington Univer-

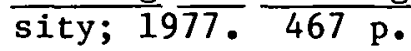

See BUILDING CODES

Dawsou, Richard. "Consumer Protection." Proceedings of the Consumer Conference on Solar Energy Development: Consumer Conference on Solar Energy Development; October 2-5, 1976; Albuquerque, NM. Albuquerque, NM: New Mexico Solar Energy Association; 1976. pp. 30-37.

SE CONSUMER PROTECTION

Environmenta1 Law Institute. Lega1 Barriers to Solar Heating and Cooling of Buildings. Springfield, VA: National Technical Information Service; 1978.

See SOLAR HEATING AND COOLING

Gevurtz, Frantolin. "nhstruction of Sunlight as a Private Nuisance." California Law Review. Vol. 65: pp. 94-119; January, 1977.

SEe LAND USE

Kraemer, Sandy F. Solar Law: Present and Future, with Proposed Forms. Colorado Springs, Co: Shepard's Inc.; 1978. 364 p.

SEe SOLAR ACCESS RIGHTS 


\section{TORT LIABILITY (Continued)}

Nyhart, J. D. "Problems of Legal Responsibilty and Liability to be Anticipated in OTEC Operations," in Ocean Thermal Energy Conversion: Legal, Political, and Institutional Aspects. Edited by H. Gary Knight, J. D. Nyhart, and Robert E. Stein. Lexington, MA: Lexington Books; 1977. 243 p.

See OCEAN ENERGY

Reitze, Glenn L. "A Solar Rights Zoning Guarantee: Seeking New Law in Old Concepts." Washington University Law Quarterly. Vol. 1976 (No. 3) pp. 376-402; Summer, 1976 .

See LAND USE 
Section 22.0

UTILITIES

AIA Research Corporation. Early Use of Solar Energy in Buildings: A Study of Barriers and Incentives to the Widespread Use of Solar Heating and

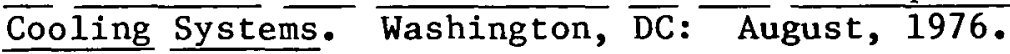

See BUILDING CODES.

Bezdek, Roger. "Legal and Regulatory Issues." Chapter IV in Analysis of Policy Options for Accelerating Commercialization of Solar Heating and Cooling Systems. Washington, DC: The George Washington University; 1977. 467 p.

See LAND USE

Bezdek, Roger. "The Solar Energy/Public Utility Interface," Chapter III in Analysis of Policy Options for Accelerating Commercialization of Solar Heating and Cooling (SHAC) Systems. Washington, DC: The George Washington University; $1977.467 \mathrm{p}$.

Available from: Local 1ibrary; NTIS, Report No. TID-27597, PC \$14.50, MF $\$ 3.00$.

SHAC systems represent an emerging technology which must compete with and, to some extent, complement an existing government-regulated utility industry. Previous research, however, has generally failed to consider the interaction of solar energy heating/cooling/service hot water systems with auxiliary systems provisions. This chapter reviews, assesses, and critiques existing research and ongoing activity in the solar/utility interface and discusses the potential impact of policy options. Specifically, the chapter does the following: (1) identifies and assesses the range of technology options that are commercially feasible with respect to the solar/utility 


\section{UTILITIES (Continued)}

interface; (2) identifies current trends in the solar energy market, with a regional assessment of the critical factors in solar energy system adoption with regard to the solar/utility interface; (3) identifies problem areas and respective remedial options associated with the solar/utility interface, with particular emphasis on legal, ratemaking, statutory, and attitude-conveyance vehicles; and (4) determines the range of impacts of policy options in the construction types of solar buildings.

Booz-Allen and Hamilton, Inc. The Effectiveness of Solar Energy. Incentives at the statc and Local Level. Washington, DC: U. S. Federal Energy Administration; March, $\overline{1976 .}$

See FINANCING/INSURANCE

Bossong, Ken. "The Case Against Private Utility Involvement in Solar/Insulation Programs." Washington, DC: Center for Science in the Public Interest, 1977.

See ANITTRUST

Davitian, Harry. The Role of Wind Power in Electric Utilities, Upton, NY: Brookhaven National Laboratory; September, 1977 .

See WIND RESOURCES

Dean, Norman L.; Miller, Alan S. "Plugging Solar Energy into the Utility Grid." Environmental Law Reporter. Vo1. 7 pp. 50069-50082; 1977.

See ANTITRUST 


\section{UTILITIES (Continued)}

Feldman, Stephen L.; Anderson, Bruce. "Financial Incentives for the Adoption of Solar Energy Design: Peak-Load Pricing of Back-Up Systeus." Solar Energy. Vol. 17 (No. 6) pp. 339-343; 1975.

Available from: Local library.

Most solar heating and cooling systems require backup energy sytems for use during prolonged periods of cloudy weather. Juxtaposing the supply and demand of solar energy against the supply and demand characteristics of electricity and natural gas demonstrates the need for peak-load pricing of standby systems. A responsive pricing system, rate variation, and time-ofday metering may be used to avoid price discrimination against solar users.

Feldman, Steven L.; Anderson, Bruce. The Public Utility and Solar Energy Interface: An Assessment of Policy Options. (Final Report) Washington, DC: U. S. Energy Research and Development Administration; December, 1976.

Available from: Local library; NTIS, Report No. DSE/2523-1, PC \$14.50, MF $\$ 3.00$.

This study reviews and critiques existing research and ongoing activity in the interface between the public utility industry and solar energy systems for buildings.

Part I examines the present state of solar/utility law and research. Part II presents the technology of solar building design, telemetry, and utility storage. Pollcy implications of utility owership and pricing are discussed in Part III. Parts IV and $\dot{V}$ examine the attitudes of decision makers in utilities and solar energy professions through interviews. A final analysis of publir policy options is also outlined. 


\section{UTILITIES (Continued)}

Feldman, S. L.; Anderson, B. Utility Pricing and Solar Energy Design. Worcester, MA: Clark University; September 30, 1976.

SEe SOLAR HEATING AND COOLING

Hillhouse, Karin H.; Kohler, E. E.; Liroff, R. A.; Miller, A. S. Legal and Institutional Perspectives on Solar Energy in Colorado: A Case Study of Land Use and Energy Decision-Making. (Final Report) Washington, DC: Environmental Law Institute; November, 1977.

See STATE LEGT.SLATTON ANO PBOGB.AMS

Kraemer, Sandy F. Solar Law: Present and Future, with Proposed Forms. Colorado Springs, $\mathrm{CO}$ : Shepard's Inc.; 1978. 364 p.

See SOLAR ACCESS RIGHTS

Lorsch, Harold G. "Effect of Solar Home Heating on Electric Utilities," in vol. 9 of Sharing the Sun! Solar Technology in the Seventies (pp. 97-112). Proceedings of the Joint Conference of the American Section, International Solar Energy Society and Solar Energy Society of Canada, Tne,, Auguet 15-20, 19yj6, Winnipeg. 10 vols. Cape Canaveral, FL: American Section of the International Solar Energy Society; 1976

See SOLAR HEATING AND COOLING

Lorsch, Harold G. Implications of Residential Solar Space Conditioning on Electric Utilities. Philadelphia, PA: Franklin Institute Research Laboratories; December, 1976.

Available from: Local library, NTIS, Report No. PB 263628 , PC \$9.25, MF $\$ 3.00$. 


\section{UTILITIES (Continued)}

This paper compares the effects on electric utilities of (1) conventional electric resistance heating, (2) direct solar heating, and (3) solar assisted heating.

While peak demand for solar and conventional homes are identical, the annual load factor for solar homes is $40 \%$ to $50 \%$ lower. Therefore, under rate structures that recover the cost to serve through an energy change alone, electric utilities will experience a revenue deficiency from those customers with solar heating, unless solar customers are charged at a different rate. However, if solar users are charged at rates which recover the actual costs to serve, their anticipated monetary savings from solar conversion will be negated.

(A summary of this article appears in Sharing The Sun, vol. 9, p. 97.)

Dean, Norman L.; Miller, Alan S. "Plugging Solar Energy into the Utility Grid." Environmental Law Reporter. Vol. 7 pp. 50069-50082; 1977

Available from: T.nçal lihrary.

Integration of solar technology with the utilities services may result in rate and service discrimination as found in variable demand pricing, regulatory burdens on multi-user solar systems, and the possible direct involvement of utilities in the solar energy market.

State statutes prohibit the state public utilities commissions (PUC) from discrimination against power users but allow for preferential treatment of certain types of users. Federal antitrust laws might provide a remedy tor solar users against utility discrimination. Service discrimination would violate the utilities' common law and statutory duty to provide utility service. Judicial review of state PUC decisions is also available, but only after all. arlministrative remedies are exhausted. 


\section{UTILITIES (Continued)}

Miller, Alan S. "Solar Energy and Land Use in Colorado." Environmental Law Reporter. Vo1. 6 pp. 50039-50046; July, 1976.

See LAND USE

Nadler, Arnold D. "Planning Aspects of Direct Solar Energy Generation." AIP Journal. pp. 339-351; October, 1977.

ECC EOLAR ACCEEE RIGHTE

Northcross, Mark. "Who Will Own the Sun?" The Progressive. Vo1. 40 (No. 4) pp. 4-16; April, 1976.

Available from: Local library.

The community-controlled. solar utility is the hest vehir.le for massive public investment in solar energy. Publicly owned solar utilities have several advantages. Utilities have large-scale borrowing and buying power that individual homeowners lack. Utility ownership and installation of solar equipment would benefit all income groups equally. Utilities are better geared for the 10 to 20-year payback pcriod for investments in solar conversion. The advantages of private utility ownership of solar equipment thus seem to be outweighed by the evils of monopoly status and the profit motive.

The major impediment facing large-scale public solar utilities is the lack of investment capital. This barrier may be overcome by a strong congressional policy mandating that implementation of solar conversion be accomplished by publicly controlled agencies operating in the public interest. 


\section{UTILITIES (Continued)}

Robertson, Bob J. "The Utility Role in Solar Commercialization." Proceedings of the Consumer Conference on Solar Energy Development: Consumer Conference on Solar Energy Development; October 2-5, 1976; Albuquerque, NM. Albuquerque, NM: New Mexico Solar Energy Association; 1976. pp. 490-502.

SEe STATE LEGISLATION AND PROGRAMS

U.S. Federal Energy Administration. Energy Rate Initiatives: Study of the Interface Between Solar and Wind Energy Systems and Electric Utilities. McLean, VA: MITRE Corporation; 1977.

Available from: Local library; NTIS, Report No. PB $265607, \$ 6.50$.

Implementation of alternative utility rate structures could impact the economics of future solar heating and cooling (SHAC) systems for buildings. Such variations in SHAC economics may affect the (1) optimum system design, (2) market penetration rate, and (3) backup energy load ultimately placed on utilities. This report discusses the problem in terms of seven key issues: (1) suitability of present approaches to ratemaking, (2) influence of load factor and peak demand on rate structures, (3) nature of the solar heating backup demand, (4) distributed energy collection, (5) backup systems, (6) utility ownership of solar heating systems, and (7) potential for oil savings. Possible govertuent actions are also suggeoted.

U.S. National Science Foundation. Legal-Institutional Implications of Wind Energy Conversion Systems (WECS). Executive Summary, by the Program of Policy Studies in Science and Technology. Washington, DC: The George Washington University; September, 1977.

See WINL RESOURCES 
THIS PAGE INTENTIMNAILLY LEFT BLANK. 
Section 23.0

WARRANTIES

Bezdek, Roger. "Building Codes, Standards, and Warranties." Chapter VI in Analysis of Policy Options for Accelerating Commerclalization of Solar Heating and Cooling Systems. Washington, DC: The George Washington University; $1977.467 \mathrm{p}$.

See BUILDING CODES

Dawson, Richard. "Consumer Protection." Proceedings of the Consumer Conference in Solar Energy Development: Consumer Conference on Solar Energy Development; October 2-5, 1976; Albuquerque, NM. Albuquerque, NM: New Mexico Solar Energy Association; 1976. pp. 30-37.

SEe CONSUMER PROTECTION

Environmental Law Institute. Legal Barriers to Solar Heating and Cooling of Buildings. Springfield, VA: National Technical Information Service; 1978.

See SOLAR HEATING AND COOLING

Kraemer, Sandy F. Solar Law: Present and Future, with Proposed Forms. Colorado Springs, CO: Shepard's Inc.; 1978. 364 p.

See SOLAR ACCESS RIGHTS

Wysocki, Bernard. "Solar Energy Devices Abound, but Many Are Useless or Inefficient." The Wall Street Journal. April 27, 1977.

Avallable from: Local library.

President Carter's plan for tax credits to homeowners and businessmen who install solar equipment opens the possibility of consumer fraud. Because 


\section{WARRANTIES (Continued)}

solar technology is in its infancy, consumers are confronted with three difficult problems: (1) identifying solar devices that work, (2) finding companies knowledgeable in installing and repairing solar equipment, and (3) avoiding opportunistic exploiters of the developing solar energy market.

Individuals investing money to become solar equipment distributors have expericnced losses because solar energy companies either have gone bankrupt or have failed to provide equipment. Snme distributore have f1led civil suits to recover their investment. 
Section 24.0

WIND RESOURCES

Davitian, Harry. The Role of Wind Power in Electric Utilities, Upton, NY: Brookhaven National Laboratory; September, 1977.

Available from: Local library; NTIS, Report No. BNL 50736, PC $\$ 4.00$, MF $\$ 3.00$.

Using current estimates, the cost of wind generated power will be competitive with conventionally generated power in the near future in those regions of the United States experiencing favorable winds and high costs of conventionally generated electricity. This assessment includes the effects of reduced reliability of wind power compared to conventional sources. Utilities employing wind power are likely to purchase more peaking capacity and less baseload capacity to provide the lower cost reserve power needed when wind outages coincide with peak loads. The monetary savings associated with this shift contribute substantially to the value of wind energy to a utility. Traditional utility analysis tools (e.g., "capacity credit," load duration curves) must be modified to provide an accurate description of wind energy's potential contribution to electricity generation.

Mayo, Louis H. Legal-Institutional Arrangements Facilitating Offshore Wind Energy Conversion Systems (WECS) Utilization. (Final Report) Washington, DC: The George Washington University; September, 1977; DOE/NSF/19137-77/3. $93 \mathrm{p}$.

Available from: Local 1ibrary; NTIS, Report No. DOE/NSF/10137-77/3, PC $\$ 6.50, \mathrm{MF} \$ 3.00$.

Establishment of offshore WECS present several legal problems relating to (1) federal-state authority and cooperation over the use of the territorial sea area and (2) national-international jurisdiction over the sea and exploitation of the ocean's resources. 


\section{WIND RESOURCES (Continued)}

The existing legal-institutional structure affecting development of alternative energy sources is adequate for the promotion of offshore WECS. The Solar Energy Act and the non-Nuclear Energy Art, fnr examplo, provide ample authority for maintaining a policy of intensive research, development, and demonstration. Similarly, existing legislation provides adequate authority for ERDA to maintain the lead agency role in a more ambitious program calling for establishment of a full-scale WECS project.

To the extent that substantially complete commercial applications nf WECS are sought, new legislation is needed to clarify incons'stencies in present law and to provide incentives.

Taubenfeld, Rita F.; Taubenfeld, Howard J. "Wind Energy: Legal Issues and Legal Barriers." Southwestern Law Journal. Vol. 31 (No. 5) pp. 1053-1093; Winter, 1977.

Available from: Local library.

The tuture development of Wind Eitugy conversion systems (WECS) w11l face legal barriers and problems dependent on their geographical location. Although problems will be minimal in sparsely populated regions, WECS in urban settings will have problems with height restrictions, zoning, aesthetics, building codes, restrictions on building design and materials, and other land use regulations. Coactal land lise is" dlso scringently regulated. Sea installation problems will depend on whether the WF.s.S are toworc or anchored floats, and on their location in internal wabur, the ceritorial sea, contiguous zone, or high seas. International agreements will affect WECS installation on the continental shelf and the seabed.

Legal problems arising from WECS development include inverse condemnation, nuisance, wind-robbing, negligence liability, interference with electronic transmissions, birds and aircraft, and energy storage. WECS will be subject 


\section{WIND RESOURCES (Continued)}

to federal regulations concerning the climate and environment, and NEPA and oSHA requirements. Interfacing WECS units with public utilities will require new rate structures, safety and interstate regulations, storage facilities, and an overall governmental regulatory strategy.

U.S. National Science Foundation. Lega1-Institutional Implications of Wind Energy Conversion Systems (WECS). Executive Summary, by the Program of Policy Studies in Science and Technology. Washington, DC: The George Washington University; September, 1977.

Available from: GPO, Stock No. 038-000-00339-9, \$4.75.

Wind energy conversion systems (WECS) can provide a benign source of power production either on land or offshore. Certain impediments, however, presently prohibit the large-scale use of WECS, including the following: difficulties in obtaining alternate power during windless periods; restrictive zoning; the preclusive effect of "regulated monopoly" structures in the electric power industry; a lack of legal basis for preventing upwind obstructions; a lack of federal solar tax and loan incentive programs applicable to WECS; state and local building, safety, and housing codes; and aesthetic objections.

Strategies can be developed to circumvent these impediments. Investor-owned and municipal utilities could provide the necessary size and capital to promote WECS ventures within or outside the existing utility regulatory structure. Such a connection could provide power during windless periods. Powers of eminent domain available to public bodies could allow for acquisition of land and upwind rights. Expansion of federal and state tax incentives to cover WECS ventures would also demonstate the necessary social and political will to overcome present restraints on WECS utilization. 


\section{WIND RESOURCES (Continued)}

Advances in WECS technology and increasing problems with conventional electrical generation may enhance the legal viability of wind systems in the future.

U.S. Energy Research and Development Administration. A National Plan for Energy Research, Development, and Demonstration: Creating Energy Choices for the Future. June, 1977.

SEe BIOMASS

U.S. Federal Energy Administration. Project Independence Blueprint: Final Task Force Report, Solar Energy. Washington, DC: Government Printing Office, 1974 .

See FEDERAL LEGISLATION AND PROGRAMS

U.S. Federal Energy Administration. Energy Rate Initiatives: Study of the Interface Between Solar and Wind Energy Systems and Electric Utilities. McLean, VA: MITRE Corporation; 1977.

S̄ee UTILITIES 
Section 25.0

GENERAL SOLAR LAW

Barnes, Peter. "Who'll Control Sun Power? The Solar Derby." The New Republic. pp. 17-19; February 1, 1975.

Available from: Local library.

Wider use of solar energy should be promoted by government, particularly through technological improvements, demonstration prograns, reform of building codes and zoning laws, and economic incentives.

Solar energy research addresses the cooling and heating of buildings through development of solar thermal conversion, photovoltaic cells, and solar panels. Conversion to solar power is being accelerated by state legislation providing production and use incentives, citizens' groups lobbying for government subsidies, and increased federal use of solar-heated buildings.

The next decade should determine whether large energy corporations, electric utilities, or the public, operating as private owners or in nonprofit groups, will control the development of the burgeoning solar industry.

Bezdek, Roger. Interim Policy Options for Commercialization of Solar Heating and Cooling Systems. Washington, DC: U.S. Energy Research and Developulent Administration; 1977; ERDA 77-62.

Available from: GPO, Stock No. 060-000-00066-2, \$2.20.

This interim report reviews the major incentive policy options to accelerate market penetration of solar heating and cooling (SHAC) systems. Feasible policy options designed to overcome existing barriers to commercíal acceptance are identified and evaluated. 


\section{GENERAL SOLAR LAW (Continued)}

The report is divided into seven sections: (1) economic and financial incentives, such as government loans, subsidies, tax inducements, and fossil fuel price deregulation; (2) public utility interface, including rate structure modification and utility ownership of solar equipment; (3) legal and regulatory issues, such as solar access, land use, antitrust, tax laws, labor law, and mortgage law; (4) patent policy; (5) building codes, standards, and warranties; (6) marketing, manpower, consumer, and environmental issues; and (7) regional aspects of the incentives program.

In each section, the most serious constraints to the widespread use of SHAC systems are isolated, and the most effective incentives to overcome these constraints are evaluated. Every major incentive likely to be considered is discussed.

Bezdek, Roger H.; Maycock, Paul D. "Incentives and Barriers to the Development of Solar Energy," in vol. 9 of Sharing the Sun! Solar Technology in the Seventies (pp. 64-73). Proceedings of the Joint Conference of the American Section, International Solar Energy Society and Solar Energy Society of Canada, Inc., August 15-20, 1976, Winnipeg. 10 vols. Cape Canaveral, FL: American Section of the International Solar Energy Soctety, 1976.

Available from: Local library; ISES members: Publishing office, 205B McDowe11 Hal1, University of Delaware, Newark, DE 19711, $\$ 50.00$ (set); Nonimembers: Pergamon Press; Maxwell House, Fairview Park, Elmsford, NY $10523, \$ 250.00$ (set).

The government must identify and rank the barriers to solar space and water heating, and develop incentives to overcome these barriers if solar energy is to achieve widespread adoption. 


\section{GENERAL SOLAR LAW (Continued)}

The barriers facing solar energy are. (ranked in order): (1) high initial cost, (2) uncertain interface with power utilities, (3) legal and regulatory problems, (4) public acceptance, and (5) building industry and labor union resistance to innovation.

Incentives lowering the high initial cost would have the most impact on solar energy adoption. Research indicates that solar energy systems can be compatibly integrated with utility companies.

The solar barriers and incentives problem is very complex. The problem must be addressed within a framework that recognizes the interdependent technological, economic, political, and social issues involved.

Burke, Kenneth J. "Alternative Forms of Energy." Lecture, Environmental Law for the Colorado Practitioner. Reprinted by Continuing Legal Education in Colorado, Inc., Denver, 1975.

Available from: Solar Energy Information Center, Solar Energy Research Institute, 1536 Cole Boulevard, Golden, C0 80401.

This article is an abbreviated version of "Legal Impediments to the Widespread Introduction of Solar Energy." It does contain, however, more information on the 1974 Solar Heating and Demonstration Act and includes additional information about the objectives of the following Energy Research and Development subprograms: (1) Solar Thermal Conversion, (2) Wind Energy Conversion, (3) Bioconversion to Fuels, and (4) Ocean Thermal Energy Conversion.

Burke, Kenneth J. "Energy and the Law: Problems and Challenges of the Late '70s," Study Materials, Copyright 1978, The American Law Institute. 
GENERAL SOLAR LAW (Continued)

Available from: Solar Energy Information Center, Solar Energy Research Institute, 1536 Cole Boulevard, Golden, CO 80401.

This presentation outlines 10 general categories of legal inquiry involved in the development of solar energy technology and suggests various means for resolving the differing and sometimes conflicting interests of solar users, designers, manufacturers, and energy suppliers. Emphasis is on Colorado law.

The following items are the 10 categories presented. (1) Because the comparatively high initial cost of equipment is a significant barrier to the widespread use of solar energy, tax and nontax incentives are suggested for consumers, producers, and the central market. (2) Although solar rights can be protected by covenants and easements, both mechanisms are of 1 imited usefulness. Zoning and other land use methods for protecting solar rights are discussed. (3) The consumer must be protected by establishing standardization and certification programs within the building industry, Warranties, track licensing, and industry self-regulation are also important. (4) Utilities might oppose solar technology as an intrusion into their established service area. (5) The institutional responses of governments, financial institutions, and insurance companies play a vital role in promoting or impeding solar growth. (6) Legal theories concerning the potential liabilities of users, architects, and engineers are examined. (7) Federal statutes covering environmental concerns are outlined, (8) Government contracting procedures can constitute barriers to the private development of technology where no patent or other proprietary rights are provided. (9) A number of federal antitrust issues are of particular importance to the energy industry-utility monopoly power, price fixing agreements, and combinations in restraint of trade. (10) Labor problems generally accompany a new technology's introduction into the construction industry. Conflicts over work assignments have occurred already. 


\section{GENERAL SOLAR LAW (Continued)}

Edelhart, Mike. "A Place in the Sun." Juris Doctor. Vol. 6 (No. 9) pp. 19-20; October, 1976.

Available from: Local library.

Solar legal issues are found in four areas: development of sun rights, marketing, public utilities, and legislation and taxation.

A solution to the problem of sun rights will be found only after the latter three problem areas have been solved, using such devices as national standards for solar hardware, load leveling to reduce utility strain, zoning laws, and tax incentives.

Harwin, Melvin; Katz, Lawrence K. "The Right To Sunshine." Solar Age. pp. 8-10; June, 1976.

Available from: Local library.

Present U.S. laws do not protect the rights of a property owner to sunlight. The vast majority of states has failed to adopt the English common law doctrine of "ancient lights," which generally prohibits an abutting landowner from interfering with the access and use of sunlight. Moreover, state legislatures have been reluctant to protect access to light because full development of the real estate industry might be hampered. Unless city planners, architects, and engineers join with lawmakers in modifying real property laws and designing new zoning ordinances, congressional efforts to promote a solar industry will be frustrated.

The author gives a hypothetical illustration of the legal difficulties involved when a property owner attempts to protect his investment in a solar energy system. The property owner generally cannot obtain an injunction to 
GENERAL SOLAR LAW (Continued)

restrain building construction that interferes with his use of sunlight. Also, cities and towns might not have developed zoning laws which establish height restrietinns.

Hundemann, Audrey S. Energy Policy and Research Planning. Vol. 1, 19641975 (A Bibliography with Abstracts). Springfield, VA: National Technical Information Service; 0ctober, 1977.

Available from: Local library; NTIS, Report No. NTIS/PS-77/0838, \$28.00.

This is a published search prepared by the National Technical Information Service from its on-line interactive bibliographic retrieval system. Citations relative to planning for future U.S. energy needs on both federal and state government levels are presented. The history and development of federal and state legislation and regulations, Project Independence studies, and assessment of the effects of deregulation are included. Technical, economic, and environmental considerations in energy planning are also covered. (This updated bibliography contains 123 abstracts, none of which is a new entry to the previous edition.)

Hundemann, Audrey S. Energy Policy and Research Planning. Vol. 2, 1976September 1977. (A Bibliography with Abstracts). Springfield, VA: National lechnical Information Service; October, 1977.

Available from: Local library; NTIS, Report No. NTIS/PS-771/0839, \$28.00.

This updated bibliography contains 235 abstracts, 141 of which are new entries to the previous edition. (See abstract for Volume 1.)

$\mathrm{A} 30 \mathrm{~b}$

Kraemer, Sandy F. "Solar Rights." Colorado Lawyer. Vol. 3 (No. 12) pp. 665-667; October, 1974.

Ava1lable from: Local library. 
GENERAL SOLAR LAW (Continued)

No established legal right to receive direct solar radiation presently exists. However, several principles and devices may be applied directly or by analogy to protect an interest in sunlight.

Sunlight received from directly overhead may be protected by injunction against encroachments. If air pollution is the source of obstruction, a lawsuit may be brought either to enforce antipollution laws or for nuisance.

Protection of sunlight from obstructions on adjoining lands may be accomplished by various uses of the following: (1) the law of nuisance, (2) acquisition of easements, (3) restrictive covenants, and (4) zoning.

Law and Solar Energy. Meeting of the Solar Energy Research Institute (SERI) and the American Bar Association (ABA). Special Committee on Energy Law. Golden, CO: Solar Energy Research Institute; February, 1978.

Avallable from: Law and Government Section, Solar Energy Research Institute, 1536 Cole Boulevard, Golden, CO 80401.

This document provides a transcript of presentations given at an inftial meeting between members of the ABA's Speical Committee on Energy, SERI staff members, and Department of Energy (DOE) representatives.

The presentations outline existing state legislation in diverse areas, including tax incentives, building codes and solar systems standards, and solar access 1aw. The ABA and the American Bar Foundation (ABF) representatives discussed ongolng research regarding solar technology compatibility with the legal system and drafting of prototype statutes for state and local governments. The DOE representative summarized (1) studies on legal barriers to solar heating and cooling, (2) cooperative efforts with the DOE's General Counsel in drafting model state legislation on energy issues, and (3) plans for establishing the Solar Law Reporter, a periodical that will contain the most recent updates on solar energy legislation. 
GENERAL SOLAR TAW (Continued)

SERI staff discussed ongoing work in technology commercialization, analysis and assessment (including creation of a solar energy data base), the visiting law professor program, the international program, the establishment of a solar/legal bibliography, and the Solar Law keporter.

Robbins, Richard L. "Law and Solar Energy Systems: Legal Impediments and Inducements to Solar Energy Systems." Solar Énergy. Vol. 18 (No. 5) pp. $371-391 ; 1976$.

Available from: Local library.

The use of solar energy in individual buildings presents eight major legal issues: (1) improving access to solar insolation, (2) optimizing the location of solar energy collectors, (3) improving the public economics of solar energy systems, (4) improving the operation and design of systems through feasible energy backup and utility involvement with solar energy, (5) removing potential construction and maintenance problems, (6) improving the climate for financing solar energy systems, (7) increasing the number of solar energy systems, and (8) allocating rights to solar insolation.

These issues may be resolved by developing solar easements, enacting favorable zoning ordinances, revising building codes, resolving labor law disputes, cooperating with public utilities, and establishing special patenting procedures.

Inducements to solar energy development include government fiscal incentives (such as special property tax rates), tax deductions, sales tax rebates, direct subsidies, consideration of life-cycle costs in financing construction, and state and local laws requiring solar equipment in new buildings. 
GENERAL SOLAR LAW (Continued)

Schifflett, Mary; Zuckerman, John V. "Solar Heating and Cooling: State and Municipal Legal Impediments and Incentives." Natura1 Resources Journal yol. 24 pp. 313-336; April, 1978.

Available from: Local library.

Solar rights must be assured by some combination of the doctrine of anclent lights, easements, zoning, eminent domain, and other legal measures. Financing for solar systems must overcome lending institution conservatism. Consumers' and manufacturers' resistance to solar conversion would be reduced by government-induced financial stimulants, such as tax incentives, favorable depreciation allowances, outright grants, low-cost loans, and development of warranty standards.

The multiplicity of building industry standards and codes must be adapted to the unique nature of solar construction. The intermittent availability of sunlight will require that utilities be integrated into solar system designs, yet several conflicts must be resolved before this integration will be successful. The high cost or unavailability of insurance for solar equipment will deter consumers who are reluctant to assume such risks themselves.

Sparrow, F. T. Incentives for and Barriers to Solar Energy: A Design for a Demonstration and Research Workshop. A.Summary Report covering the Proceedings of the Workshop under Contract No. E (29-2) 3750. Houston, TX: University of Houston; September, 1976.

Available from: Solar Energy Information Center, Solar Energy Research Institute, 1536 Cole Boulevard, Golden, CO 80401.

This report summarizes the workshop proceedings of solar research investigators, environmental lawyers, and sociologists regarding the political, 
GENERAL SOLAR L

legal, technological, institutional, economic, and social barriers to solar energy development. Research findings indicate the need for additional research in diverse areas: (1) industry-w1de standards and technical performance warranties, (2) status of state and local programs to encourage solar energy, and (3) regional federal policies to promote solar energy use. The Environmental Research Institute identified the following three areas for highest research priority: (1) solar/utility interface, (2) land use planning, and (3) solar access. Research rnnrlusinns and rocommondationo to develop incentives for and remove barriers to solar energy are also discussed.

Thomas, William A. Proceedings of the Workshop on Solar Energy and the Law, February 10, 1975, Arlington, Va, An Interim Report Submitted to the National Science Foundation. Chicago, IL: American Bar Foundation; March, 1975.

Available from: Loca1 library; NTIS, Report No. PB 241051 , PC \$4.50, MF $\$ 3.00$.

Workshop participants discuss the elimination of impediments to and the creation of incentives for the development of solar energy technology under four broad subjects: building codes, access to light, fiscal incentives, and land use planning.

A multiplicity of building codes discourages solar technological innovation. Moreover, innovation is impeded by insufficient effort to refine building regulation standards.

The English common law doctrine of ancient lights could be modified to accommodate increased use of solar energy for heating and cooling; but because this doctrine has been rejected in the United States, a property owner must protect his right to lateral light by purchasing negative easements from adjacent nelghbors. Given the appropriate conditions, nuisance law might be an alternative. 


\section{GENERAL SOLAR LAW (Continued)}

Four fiscal impediments discourage the use of solar devices: (1) solar devices cause property assessment increases due to the added value of the property; (2) banks might refuse mortgages on solar-heated houses because tax laws inadequately assess their value; (3) public utility costs would tend to be higher for solar energy used because of infrequent use; and (4) contractors might avoid working with solar collectors because the uncertain characterizations of solar devices could lead to labor disputes.

Innovative land use laws and regulations are necessary to facilitate solar energy development. Attention must be paid to the coordination of private and public interests, intergovernmental relationships, and private sources of capital.

U.S. Department of Energy. Assistant Secretary for Conservation and Solar Applications. Solar Energy Incentives Analysis: Psycho-economic Factors Affecting the Decision Making of Consumers and the Technical Delivery System. January, 1978 .

Available from: Local library; NTIS, Report No. HCP/M 2534-01, PC \$5.25, MF $\$ 3.00$.

Several psycho-economic factors help explain why favorable attitudes toward solar energy have not been converted into significant levels of investment or buying. Both consumers and manufacturers are deterred by the perceived risks associated with the uncertain future of solar technology and reliability. Approximately 10 years of system use at lower operational costs is required to overcome the higher initial system cost and result in a payoff of the investment; and a time span runs counter to the psychological need for immediate gratitication. Solar energy has not been adopted by the significant "peer" or "authority" group necessary to stimulate widespread "follow-the-leader" behavior. 


\section{GENERAL SOLAR LAW (Continued)}

Federal, state, and local governments may adopt several policies to reduce perceived risks, provide immediate payoffs, and achieve widespread consensus about the value of solar energy. Such programs might include tax incentives, low-cost loans, subsidies, further research and development efforts, information and educational programs, building code modification, development of standards, and promotion of utility company involvement. 


\section{AUTHOR/TITLE INDEX}

AIA Research Corporation, Early Use of Solar Energy in Buildings: A Study of Barriers and Incentives to the Widespread Use of Solar Heating and Cooling Systems. See BIILDING CoDES, p. 7 .

AMERICAN Law Reports, "Express Easement of Light, Air, and View." See SOLAR ACCESS RIGHTS, p. 85.

ANDERSON, Bruce, "Financial Incentives for the Adoption of Solar Energy Design: Peak-Load Pricing of Back-Up Systems." See UTILITIES, p. 125.

ANDERSON, Brice, The Public Utility and Solar Energy Interface: An Assessment of Policy Options. See UTILITIES, p. 125 .

ANDERSON, Bruce, "The Sun in a Drawer." See BUILDING CODES, p. 7.

ANDERSON, Bruce, Utility Pricing and Solar Energy Design. See SOLAR HEATING AND COOLING, p. 95 .

ARTHUR D. Little, Inc., Residential Solar Heating and Cooling Constraints and Incentives. A Review of the Literature. See SOLAR HEATING AND COOLING, p 93 .

BARNES, Peter, "Who'11 Control Sun Power? The Solar Derby." See GENERAL SOLAR LAW, p. 137.

BARRET, DAVID, Financing the Solar Home. See FINANCING/INSURANCE, p 31. BECKER, Ralph E., Jr., "Common Law Sun Rights:. An Obstacle to Solar Heating and Cooling?" . See LAND USE, p. 52.

BEN-DAVID, Shaul, "Near-Term Prospects for Solar Energy: An Economic Analysis." See FINANCING/INSURANCE, p. 31 .

BERSOHN, David L., "Securing Solar Energy Rights: Easements, Nuisance or Zoning." See LAND USE, p. 53.

BEZDEK, Roger, "Building Codes, Standards, and Warranties." See BUILDING CODES, p. 8 .

BEZDEK, Roger, "Economic and Financial Incentives." See FINANCING/INSURANCE, p. 32 .

BEZDEK, Roger, "Energy Research and Development Administration (ERDA) Patent Policy." See PATENTS AND LICENSES, p. 79.

BEZDEK, Roger, "Incentives and Barriers to the Development of Solar Energy." See GENERAL SOLAR LAW, p. 138.

BEZDEK, Roger, Interim Policy options for Commercialization of Solar Heating and Cooling Systems. See GENERAL SOLAR LAW, p. 137. 
AUTHOR/TITLE INDEX (continued)

BEZDEK, Roger, "Legal and Regulatory Issues." See LAND USE, p. 53. BEZDEK, Roger, "Marketing, Manpower, Consumer, and Environmental Issues." See LABOR, p. 51.

BEZDEK, Roger, "Regional Aspects of the Incentive Program." See FEDERAL LEGISLATION AND PROGRAMS, p. 19.

BEZDEK, Roger, "The Solar Energy/Public Utility Interface." See UTILITIES, p. 123 .

BINNS, W. Patrick, "State Legislative Initiatives for Solar Energy Implementation." See STATE LEGISLATION AND PROGRAMS, p. 107.

BLAIR, John F., Jr., "Some Institutional Problems of Residential Solar Heating." See FINANCING/INSURANCE, p. 22.

BLIAMPTIS, E. E., "Rights to Sunshine." See SOLAR ACCESS RIGHTS, p. 82. BOOZ-ALLEN and Hamilton, Inc., The Effectiveness of Solar Energy Incentives at the State and Local Level. See FINANCING/INSURANCE, p. 34 .

BOSSONG, Ken, "The Case Against Private Utility Involvement in Solar/Insulation Programs." see AN'll'kUS'l, p. 1 .

BRADLEY, Jerry U., "'lechno-Économic Aspects of a Photovoltaic Electric Power System Interfaced with Electric Power Utilities." See PHOTOVOLTAICS, p. 81 .

BURKE, Kenneth J., "Alternative Forms of Energy." See GENERAL SOLAR LAW, $P$ : 134 :

BURKE, Kenneth J., "Energy and the Law: Problems and Challenges of the Late '70s." See GENERAL SOLAR LAW, p. 139.

$\underline{B U R Y}$ v. Pope. See INTERNATIONAL LAW, p. 43.

CALIFORNIA Energy Resources Conservation and Development Commission, "Solar Energy in California: Residential Thermal Application." See STATE LEGISLATION AND PROGRAMS, p. 107.

CARLSON, R. C., "Solar Energy: Has the Time Come?" See FINANCING/INSURANCE, P. 35.

CARUSO, Lawrence R.; Caruso, Linda, "International Cooperation in the Production of Solar Energy Through the Use of Satellites." See INTERNATIONAL LAW, p. 43.

CHARLES Semon and Co. Ltd. v. Bradford Corp. See INTERNATIONAL LAW, p. 43. 


\section{AUTHOR/TITLE INDEX (continued)}

CHATEL, BERTRAND, "Some Solar Energy Programmes of the United Nations System." See INTERNATIONAL LAW, p. 44.

COHEN v. Perrino. See SOLAR ACCESS RIGHTS, p. 84.

COLLS v. Home and Colonia1 Stores Ltd. See INTERNATIONAL LAW, p. 44. CONE, B. W., An analysis of Federal Incentives Used to Stimulate Energy Production. See FEDERAL LEGISLATION AND PROGRAMS, p. 19.

COSTELLO, Dennis R., "Techno-Economic Aspects of a Photovoltaic Electric Power System Interfaced with Electric Power Utilities." See PHOTOVOLTAICS, p. 81 .

DAMON, Peter S., "Financing Solar Systems Costs." See FINANCING/INSURANCE, P. 35 .

$\underline{\text { D'AURIO }}$ v. Board of Zoning Appeals. See LAND USE, p. 84.

DAVITIAN, Harry, The Role of Wind Power in Electric Utilities. See WIND RESOURCES, p. 133.

DAWSON, Richard, "Consumer Protection." See CONSUMER PROTECTION, p. 13. DEAN, Norman L., "Plugging Solar Energy into the Utility Grid." See ANTITRUST, p. 2 .

DEENY, Raymond, "Legal Aspects of Solar Energy Development." See LAND USE, p. 65 .

DICKSON, Edward M., Control of Environmental Impacts from Advanced Energy Sources. See ENVIRONMENTAL ASPECTS, p. 16 .

DIKKERS, Robert D., "Development and Implementation of Standards for Solar Heating and Cooling Applications." See SOLAR HEATING AND COOLING, p. 94.

EDELHART, Mike, "A Place in the Sun." See GENERAL SOLAR LAW, p. 141.

EISENHARD, Robert M., Building Energy Authority and Regulations: State Activity. See STATE LEGISLATION AND PROGRAMS, p. 108.

EISENHARD, Robert "M., State Solar Energy Legislation of 1976: A Review of Statutes Relating to Buildings. See STATE LEGISLATION AND PROGRAMS, p. $10 \overline{8}$.

EISENSTADT, Melvin M., "A Proposed Solar Zoning Ordiance." See LAND USE, p. 55 . 
AUTHOR/TITLE INDEX (continued)

EISENSTADT, Melvin M., "Solar Rights and Their Effect on Solar Heating and Cooling." See LAND USE, p. 55.

EISENSTADT, Melvin M., "Solar Rights and Their Effect on Solar Heating and Cooling." See LAND USE, p. 56.

ENVIRONMENTAL Law Institute, Legal Barriers to Solar Heating and Cooling of Buildings. See SOLAR HEATING AND COOLING, p. 95 .

EPSTEIN, Peter, Financing the Solar Home. See FINANCING/INSURANCE, p. 31. EZRA, Arthur A., "Technology Utilization: Incentives and Solar Energy." SEe FEDERAL LEGISLATION AND PROGRAMS, p. 20.

FANNIN, Paul, "Solar Energy: Overcoming the Barriers." See FINANCING/ IPSURANCE,

FELDMAN, Stephen L., "Financial Incentives for the Adoption of Solar Energy Design: Peak-Load Pricing of Back-Up Systems." See UTILITIES, p. 125.

FELDMAN, Stephen L., The Public Utility and Solar Energy Interface: An Assessment of Policy options. See UTILITIES, p. 125.

FELDMAN, Stephen L., Utility Pricing and Solar Energy Design. See SOIAR HEATING AND COOLING, p. 95 .

FELT, James G.," "Solar Shade Control." See LAND USE, p. 59.

FUN'ALNEBLEAU Hotel Corp. v. Forty-Five Twenty-Five, Inc. See SOLAR ACCFSS RIGHTS, $p, 85$.

FOSTER, Harold D., "Daedalophobia: Diagnosis and Prognosis." See INTERNATTONAI. I,AW, p. 45 .

GENERAL Electric Company, General Electric Company Survey to Define Impact of Statewide Building Codes on Solar HVAC Systems: Commercial Buildings.

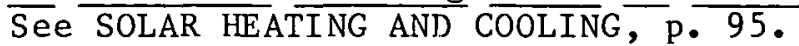

GEVURTZ, Franklin, "Obstruction of Sunlight as a Private Nuisance." See LAND USE, p. 57.

GOBLE, Dale D., "Solar Rights: Guaranteeing a Place in the Sun." See SOLAR ACCESS RIGHTS, p. 85. 
AUTHOR/TITLE INDEX (continued)

GREAT Britain, Rights of Light Act. See INTERNATIONAL LAW, p. 45. GREENE, W. A., "Easement of Light." See INTERNATIONAL LAW, p. 46. GREENE, W. A., "Rights of Light." See INTERNATIONAL LAW, p. 46. GREENE, W. A., "Right to Light." See INTERNATIONAL LAW, p. 46.

HAAR, Charles M., Financing the Solar Home. See FINANCING/INSURANCE, p. 31. HALACY, Dan, "Federal Solar Legislation." See FEDERAL LEGISLATION AND YKUGKAMS, p. 21.

HALLBERG, C. R., "International Regulatory Authority Concerning Ocean Thermal Energy Conversion Devices." See OCEAN ENERGY, p. 71.

HARRIS, William R., Is the Right to Light a California Necessity? See STATE LEGISLATION AND PROGRAMS, p. 109 .

.HARWIN, Melvin, "The Right to Sunshine." See GENERAL SOLAR LAW, p. 141.

HERWIG, Lloyd O., "Report on United States International Cooperation in Solar Energy Technology Development." See INTERNATIONAL LAW, p. 47.

HIGGINS, James C., "Ocean Thermal Energy Conversion Plants: Federal and State Regulatory Aspects." See OCEAN ENERGY, p. 71.

HILLHOUSE, Karin II., Legal and Institutional Perspectives on Solar Energy in Colorado: A Case study of Land Use and Energy Decision-Making. See $\overline{\text { STATE LEGISLATION AND PROGRAMS, }} \overline{\text { P. } 110}$.

HILlHOUSE, Karin H., "Solar Energy--Its Environmental Dimensions." See ENVIRONMENTAL ASPEC"I'S, p. 15.

HIRSHBERG, Alan S., "Barriers to the Widespread Utilization of Residential Solar Energy: The Prospects for Solar Energy in the U.S. Housing Industry." See BUILDING CODES, p. 9.

HIRSHBERG, Alan S., "Public Policy for Solar Heating and Cooling." See FINANCING/INSURANCE, p. 36 .

HOLLICK, Ann L., "International Politica1 Implications of Ocean Thermal Energy Conversion Systems." See OCEAN ENERGY, p. 72.

HUGHES, Evan E., Control of Environmental Impacts from Advanced Energy Sources. See ENVIROMENTAL ASPECTS, p. 16 .

HUNDEMANN, Audrey $S_{.,}$Energy Policy and Research Planning. Vo1. 1, 19641975 (A Bibliography with Abstracts.) See GENERAL SOLAR LAW, p. 142. 
AUTHOR/TITLE INDEX (continued)

HUNDEMANN, Audrey S., Vol. 2 1976-September 1977. See GENERAL SOLAR LAW, p. 142 .

HYATT, Sherry V., "Thermal Efficiency and Taxes: The Residential Energy Conservation Tax Credit." See FINANCING/INSURANCE, p. 37.

INDUSTRY Week, "Fast Growing Solar Industry has 'Clouds'." See FEDERAL LEGISLATION AND PROGRAMS, p. 21 .

The JAPAN Economic Journal, "Urban Problems: Right to Sunlight." See IN'I'E'RNA'I'LUNAL LAW, p. $4 \dot{y}$.

JOHNSON, Augustus C., "Cotille rcialization of S̉olar Heating and Cooling of Buildings." See SOLAR HEATING AND COOLING, p. 96.

JOHNSON, Milan, Solar Energy Commercialization at the State Level: The Florida Solar Energy Water Heater Program. See STATE LEG ISLATION AND PROGRAMS, P. 111 .

JONES, Nancy Lee, Solar Rights: The Present Status of Legal Access to Light and Possible Constitutional objections to Federal Legislation. See FEDERAL LEGISLATION AND PROGRAMS, $\mathrm{p} .22$.

JONES, R. G., Analysis of State Solar Energy Policy Options. See STATE LEGISLATION AND PROGRAMS, $, \overline{\mathrm{p}}, 112$.

KATZ, Lawrence K., "The Right to Sunshine." See GEÑERAL ŚȮÄ̉ LAW̆, p. 141.

KNIGHT, H. Gary, "International Jurisdictional Issues Involving OTEC Installation." See OCEAN ENERGY, p. 72.

KÓHLER, E. E., Legal and Institutional Perspectives on Solar Energy in Colorado: A Case Study of Land Use and Energy Decision-Making. See STATF. LEGISLATION AND PROGRAMS, p. 110 .

KRAEMER, Sandy F., Solar Law: Present and Future, with Proposed Forms. See SOLAR ACCESS RIGHTS, p.

KRAEMER, Sandy F., "Solar Rights." See GENERAL SOLÀr LAW, p. 142.

KRAEMER, Sandy F., "Solar Shade Control." See LAND USE, p. 59.

LEPORE, John A., "Residential Solar Heating Retrofit in the Urban Environment." See ENVIRONMENTAL ASPECTS, p. 16. 
AUTHOR/TITLE INDEX (continued)

LIOR, Noam, "Residential Solar Heating Retrofit in the Urban Environment." See ENVIRONMENTAL ASPECTS, p. 16.

LIROFF, R. A., Legal and Institutional Perspectives on Solar Energy in Colorado: A Case Study of Land Use and Energy Decision-Making. See STATE LEGISLATION AND PROGRAMS, $\mathrm{p}$. 110.

LONG, Stephen, "A Proposed Solar Zoning Ordinance." See LAND USE, p. 55.

LORSCH, Harold G., "Effect of Solar Heating on Electric Utilities." See SOLAR HEATING AND COOLING, p. 97.

LORSCH, Harold G., Implications of Residential Solar Space Conditioning on Electric Utilities. See UTILITIES, p. 126 .

MAGNAS, Howard L., Solar Energy Projects of the Federal Government. See HEDERAL LEGISLATION AND PROGRAMS, p. 23.

MAIORIELLO v v Arlotta. See SOLAR ACCESS RIGHTS, p. 87.

MAIZE, Kennedy P., "A Look at the Sunny Side: Government R \& D Programs." See FEDERAL LEGISLATION AND PROGRAMS, p. 23.

MAYCOCK, Paul D., "Incentives and Barriers to the Development of Solar Energy." See GENERAL SOLAR LAW, p. 138.

MAYO, Louis H., Legal-Institutional Arrangements Facilitating Offshore Wind Energy Conversion Systems (WECS) Utilization. See WIND RESOURCES, p. 133.

MILLER, A. S., Legal and Institutional Perspectives on Solar Energy in Colorado: A Case Study of Land Use and Energy Decision-Making. See STATE LEGISLATION AND PROGRAMS, $\mathrm{p}$. 110 .

MILLER, $\Lambda$ lan S., "Plugging Solar Energy into the Utility Grid." See ANTITRUST, p. 2 .

MILLER, Alan S., "Solar Energy and Land Use in Colorado." See LAND USE, p. 59 .

MILLER, Alan S., "Solar Energy and Public Lands." See LAND USE, p. 60.

MILLS, Jon, "Energy Policy: A Test for Federalism." See FEDERAL LEgISLATION AND PROGRAMS, p.24.

MOORE, Elizabeth C., "For Potential Customers for Solar Equipment: No News is Bad News." See STANDARDS, p. 103.

MOORE, J. Glenn, Solar Energy Legislation in the 95th Congress: January through August 1977 (Updated through November 1977.) See FEDERAL LEGISLATION AND , PROGRAMS, p. 25 . 


\section{AUTHOR/TITLE INDEX (continued)}

MOSKOWITZ, Daniel P., "Legal Access to Light: The Solar. Imperative." See SOLAR ACCESS RIGHTS, p. 88.

MYERS, Barry Lee, "Solar Access Rights in Residential Developments." See SOLAR ACCESS RIGHTS, p. 89.

NADLER, Arnold D., "Planning Aspects of Direct Solar Energy Generation." See SOLAR ACCESS RIGHTS, p. 89.

NAEF, Frederick E., "Economic Aspects of Ocean Thermal Energy Conversion." See OCEAN ENERGY, p. 73.

NEW YORK State Legislative Commission on Energy Systems, A Forum nn Solar Access. See STATE LEGISLATION AND PROGRAMS, p. 112.

NORTHCROSS, Mark, "Who will Own the Sun?" See UTILITIES, p. 128.

NOTE, "Taxation of Easement in Airspace. See LAND USE, p. 61.

NYHART, J. D., "Problems of Legal Responsibility and Liability to be Anticipated in OTEC Operations." See OCEAN ENERGY, p. 74.

O'BRIEN, Josephine, "Some Institutional Problems of Residential Solar Heating." See FINANCING/INSURANCE, p. 33.

PARKER and Edgarton v. Foote. See SULAR ACCESS RIGHTS, p. 90.

PELSTER, Joette M., Analysis of State Solar Energy Policy Options. See STATE LEGISLATION AND PROGRAMS, p. 112 .

PETERSEN, H. Craig, 'lhe Impact of Tax Incentives and Auxiliary Fuel Prices on the Utilization Rate of Solar Energy Space Conditioning. See TAX LAW, p. $\overline{118}$.

PHELPS, Dennis L., "Solar Energy: An Analysi.s of the Implementation of Solar Zoning." See LAND USE, p. 62.

PHILLIPS, J. D., Assessment of a Single Family Residence Solar Heating System in a Suburban Development Setting. See LOCAL LEGISLATION AND PROGRAMS, $\overline{\text { p. }}$ 67.

PREZYNA, Ann E., "Utilizing Solar Power--The Institutional Challenges." See CONSUMER PROTECTION, P. 14 . 


\section{AUTHOR/TITLE INDEX (continued)}

REISMEYER, Frederick H., "The Development of Alternative Energy Sources: A Legal and Policy Analysis." See FINANCING/INSURANCE, p. 39.

REITZE, Arnold W., Jr., "Utilizing Solar Power--The Institutional Challenges." See CONSUMER PROTECTION, p. 14.

REITZE, Arnold W., Jr., "Protecting a Place in the Sun." See LAND USE, p. 63 .

REITZE, Glenn L., "A Solar Rights Zoning Guarantee: Seeking New Law in Old Concepts." See LAND USE, p. 63.

RIGGS, John H., "Legal Aspects of Financing Ocean Thermal Energy Plants." See OCEAN ENERGY, p. 75.

ROBBINS, Richard L., "Building Codes, Land Use Controls, and Other Regulations to Encourage Solar Energy Use." See STATE LEGISLATION AND PROGRAMS, p. 113 .

ROBBINS, Richard L., "Law and Solar Energy Systems: Legal Impediments and Inducements to Solar Energy Systems." See GENERAL SOLAR LAW, p. 144.

ROACH, F., Prospects for Solar Energy: The Impact of the National Energy Plan. See TAX LAW, P. 119 .

ROBERTSON, Bob J., "The Utility Role in Solar Commercialization." See STATE LEGISLATION AND PROGRAMS, p. 114 .

SCHIFFLETT, Mary, "Solar Heating and Cooling: State and Municipal Legal Impediments and Incentives." See GENERAL SOLAR LAW, p. 145.

SCHMIDT, Richard A., Control of Environmental Impacts from Advanced Energy Sources. See ENVIRONMENTAL ASPECTS, p. 16 .

SCHOEN, Richard, "Barriers to the Widespread Utilization of Residential Solar Energy: The Prospects for Solar Energy in the U.S. Housing Industry." See BUILDING CODES, p. 9.

SCOTT, Ronald D., "The United States National Program for the Demonstration of Solar Heating and Cooling in Buildings: Progress Report." See BUILDING CODES, p. 10 .

SEWELL, W. R. Derrick, "Daedalophobia: Diagnosis and Prognosis." See INTERNATIONAL LAW, p. 45.

SHORE, Sidney, "Residential Solar Heating Retrofit in the Urban Environment." See ENVIRONMENTAL ASPECTS, p. 16.

SMITH, A. E., "Solar Energy Application Considerations for Housing in Depressed Communities." See FINANCING/INSURANCE, p. 39. 
AUTHOR/TITLE INDEX (continued)

SOLAR Energy Research Institute, "Meeting of the Solar Energy Research Institute and the American Bar Association." Law and Solar Energy. See GENERAL, SOLAR LAW, p. 143.

SOLOMON, Lewis D., "The Development of Alternative Energy Sources: A T,egal and Policy Analysis." See FINANCING/INSURANCF, p. 39.

SPARROW, F. T., Incentives for and Barriers to Solar Energy: A Design for a Demonstration and Research Workshop. See GENERAL SOLAR LAW, p. 145.

SPERBER, Phillip, "Government Contracting: Perpetrating the Energy Crisis." See PATENTS AND LICENSES, p. 80.

STRANCK, Helen M., Analysis of State Solar Energy Policy Options. See STATE LEGISLATION AND PROGRAMS, p. 112 .

TAUBENFELD, Rita F.; Taubenfeld, Howard J., "Wind Energy: Legal Issues and Legal Barriers." See WIND RESOURCES, p. 134.

TIEDEMANN, Thomas F., Solar Energy Commercialization at the State Level: The Florida Solar Energy Water Heater Program. See STATE LEG ISLATION AND PROGRAMS, p. 111 .

THOMAS, William A, Proceedings of the Workshnp nn Sn1ar Energy and the. Law. See GENERAL SOLAR LAW, p. 146 .

UNITED STATES v. CaUSbY. SEe LANU USE', p. 63.

U.S. Congress. House. Committee on Banking, Currency and Housing., Low-Interest Loans for Residential Solar Heating and Cooling Equipment. See FINALCING/INSURANCE, p. 40 .

U.S. Congress. House. Solar Ēnergy Legislation Through the 94th Congress. See FEDERAL LEGISLATION AND PROGRAMS, $\mathrm{p}$. 26 .

U.S. Congress. House. Subcommittee on Energy Research, Development, and Demonstration of the Committee on Science and Technology, A Guide to Federal Programs of Possible Assistance to the Solar Energy Community. See FEDERAL $\overline{\text { LEGISLAT ION }} \overline{\text { AN PROGRAMS, p. } 27 .}$

U.S. Congress. Joint Economic Committee. The Economics of Solar Energy. See FEDERAL LEGISLATION AND PROGRAMS, p. 27.

U.S. Congress. Senate. Select Committee on Small Business, Energy Research and Development and Smal1 Business. See FEDERAL LEGISLATION AND PROGRAMS, p. 28 . 
AUTHOR/TITLE INDEX (continued)

U.S. Department of Housing and Urban Development (HUD), National Bureau of Standards, and U.S. Department of Commerce, Interim Performance Criteria for Solar Heating and Combined Heating/Cooling Systems and Dwellings. See SOLAR HEATING AND COOLING, p. 98 .

U.S. DOE. Assistant Secretary for Conservation and Solar Applications, Solar Energy Incentives Analysis: Psycho-economic Factors Affecting the Decision Making of Consumers and the Technical Delivery System. See GENERAL SOLAR LAW, p. 147 .

U.S. Energy Research and Development Administration, A National Plan for Energy Research, Development, and Demonstration: Creating Energy Choices for the Future. See BIOMASS, p. 5 .

U.S. Energy Research and Development Administration, Division of Solar Energy, National Program for Solar Heating and Cooling (Residential and Commercial Applications.) See FEDERAL LEGISLATION AND PROGRAMS, p. 29.

U.S. Federal Energy Administration, Energy Rate Initiatives: Study of the Interface Between Solar and Wind Energy Systems and Electric Utilities. See UTILITIES, p. 129 .

U.S. Federal Energy Administration, Project Independence Blueprint: Final Task Force Report, Solar Energy. See FEDERAL LEGISLATION AND PROGRAMS, p. 29.

U.S. Federal Energy Administration, Solar Heating and Cooling of Buildings (SHACOB) Commercialization Report. See SOLAR HEATING AND COOLING, p. 99.

U.S. Federal Trade Commission. Bureau of Competition, The Sular llarket: Proceedings of the Symposium on Competition in the Solar Energy Industry. See STANDARDS, P. 104 .

U.S. ERDA. Division of Solar Energy, Solar Access and Land Use: State of the Law, 1977. See LAND USE, p. 64.

U.S. National Science Foundation, Legal-Institutional Implications of Wind Energy Conversion Systems (WECS). See WIND RESOURCES, p. 135 .

U.S. National Solar Heating and Cooling Information Center, State Solar Legislation. See STATE LEGISLATION AND PROGRAMS, p. 115 .

UTTON, Albert E., "A Proposed Solar Zoning Ordinance." See LAND USE, p. 55.

UTTON, Albert E., "Solar Rights and Their Effect on Solar Heating and Cooling." See LAND USE, p. 55.

UTTON, Albert E., "Solar Rights and Their Effect on Solar Heating and Coollng." SeE LAND UEE, p. 56. 


\section{AUTHOR/TITLE INDEX (continued)}

WAKSMAN, D., Plan for the Development and Implementation of Standards for Solar Heating and Cooling Applications. See STANDARDS, p. 105.

WASHOM, Byron, "Spatial and Emerging Use Conflicts of Ocean Space." See OSF.AN F.NFRSY, r. 76.

WHITE, Mary D., "The Allocation of Sunlight: Solar Rights and the Prior Appropriation Doctrine." See SOLAR ACCESS RIGHTS, p. 91.

WHITE, Sharon, Santa Clara, California Cummunity Center: Commercial Solar Demonstration, Legal Alternatives, Tmplieations, and Financing of golai Heating and Cooling by a Municipal Corporation. see LOCAL LEGISLATION AND FROGRANIS, $\mu .68$.

WILKINSON, H. W., "Let There Be More Light." See INTERNATIONAL LAW, p. 49. WILLIAMS, John Eddie, Jr., "The Dawning of Solar Law." See LAND USE, p. 65. WOODSON, R. D., "Energy Pollcy: A Test for Federalism." See FEDERAL LEGISLATION AND PROGRAMS, p. 24.

WYSOCKI, Bernard, "Solar Energy Devices Abound, but Many Are Useless or Inefficient." See WARRANTIES, p. 131.

YIM, Herbert C., "Report on United States International Cooperation in Solar Energy Technology Development." See T.NTERNATIONAL LAW, p. 47.

YOXALL, Richard R., "Solar Energy: An Analysis of the Implementation of Solar Zoning." See LAND USE, p. 62.

ZILLMAN, Donald N., "Legal Aspects of Solar Energy Development." See LAND JSE, $\mu .55$.

ZUCKERMAN, John V.." "Snlar Heating and rooling: Stote and Municipal Legal Impediments and Incentives." See GENERAL SOLAR LAW, p. 145. 